Heráclito Barbosa de Carvalho

\title{
Dinâmica de Transmissão do HIV entre Usuários de Drogas Injetáveis, na cidade de Santos, São Paulo, Brasil.
}

Tese Apresentada À Faculdade DE Medicina DA Universidade de São PaUlo PaRA OBTENÇÃo do Título DE DOUTOR EM MEDICINA

Área de ConcentraÇÃo: PATOlogia

Orientador: Prof. Dr. EduARdo Massad

SÃO PAULO

- 1995 - 


\title{
Apoio Financeiro
}

Esta tese teve o apoio financeiro das seguintes instituições:

\author{
FAPESP 92/3419-4 \\ CAPES \\ LIM 01-HC-FMUSP
}

FOGARTY FUNDATION

EMBRABIO LTD. 


\section{Dedicatória}

à Silvia, as Guilherme, e à Adriama 


\section{Agradecimentos}

Ao meu orientador, Dr. Eduardo Massad, professor associado da Disciplina de Informática Médica do Departamento de Patologia da FMUSP, pela oportunidade de participar de um projeto de pesquisa; incentivando, discutindo, concordando, discordando, colaborando dessa maneira para a minha formação pessoal e profissional;

A meus pais Eleazar e Rosa por terem me proporcionado condições de seguir a carreira medica; ensinando-me a ser forte diante das dificuldades que a vida nos apresenta;

Dona Nena, líder comunitária, residente na região do cais do porto de Santos, cuja participação, confiança e determinação, tornou possível o acesso a esta comunidade de usuários de drogas da região;

Dr. Andrew Moss, pesquisador de Epidemiologia da Universidade da California, pela sua assessoria nos trabalhos de campo, orientando o estudo do WHO - Colaborative Study Group;

Dr. Samuel R. Friedman do Instituto Nacional de Desenvolvimento e Pesquisas de Nova Iorque, pelas valorosas contribuições nas análises;

Aos colegas da disciplina de informática, onde desenvolvi este trabalho: o Dr. Renato Accioly por ter me ajudado nos primeiros contatos com a linguagem computacional; os doutores Hyun Mo Yang, Paulo Sérgio Panse Silveira e Silvia Regina Dias Médici Saldiva pelo incentivo pessoal sempre presente e a colaboração oportuna com idéias e sugestões;

Dr. Milton Arthur Ruiz do Hemocentro Central do Hospital Guilherme Álvaro da Faculdade de Ciências Médicas de Santos e Dra. Vera Marão do Laboratório Central do HCFMUSP pelo apoio dado para que pudessem ser realizados os exames laboratoriais; 
Elza Maria Ferreira de Mello Faro, Eunice Laurente Teófilo Prieto, Sandra Lúcia Furquim de Campos que participaram com grande entusiasmo e dedicação da execução dos exames laboratoriais,

Dr. Raymundo Soares de Azevedo Neto, na orientação dos exames laboratoriais mais adequados a serem utilizados neste trabalho, quando da execução do projeto inicial;

Dra. Vera Aparecida dos Santos, pela sua assessoria no capítulo relacionado aos aspéctos imunológicos da AIDS, e aspectos teóricos dos exames laboratoriais efetuados no trabalho;

Dr. Fábio Mesquita, Regina Bueno Carvalho e Giselda Turienzo Lopes pesquisadores do Instituto de Estudo e Pesquisas de AIDS de Santos (IEPAS) e integrantes do WHO - Colaborative Study Group na participação efetiva do trabalho de campo;

Dr. Marcelo Nascimento Burattini, pela sua participação nas discussões teóricas e na análise dos dados de campo,

Prof. Francisco Antônio Bezerra Coutinho, pela participação no desenvolvimento do modelo matemático aplicado,

A Maria Odila de Mattos Fabiani, pelo árduo trabalho de correção gramatical deste trabalho. A necessidade de constantes alterações do texto, principalmente na sua versão final, pode ter criado condições para que partes dele não tenha sido por ela revisados e que, as prováveis falhas gramaticais ocorridas, sejam de minha responsabilidade.

Aos vários colegas da área que de forma direta ou indireta colaboraram com este trabalho. 
RESUMO

SUMMARY

CONVENÇÕES.

INTRODUÇÃO 1

1. Motivação 2

2. AIDS

Histórico

Origem da epidemia

$O$ agente

Infecção pelo HIV na espécie humana____ 14

Mecanismos pelos quais os HIVs causam imunossupressão ___ 15

Transmissão do HIV __ 16

Presença do vírus__ 16

Aspectos clínicos__ 16

Aspectos laboratoriais __ 17

Aspectos gerais da pandemia e seus números___ 21

Impacto social ___ 22

Perfil epidemiológico __ 24

Tendências _ 26

No Brasil __ 27

Infecção em grupos com comportamento de risco ___ 28

A epidemia de AIDS nas comunidades de UDIs ___ 29 
Estratégias de controle

Diagnóstico

Tratamento

Vacinas

3. Infecções com padrão similar de transmissão 33

Retroviroses do homem _ 33

Hepatites _ 34

Sífilis _ 36

Aspectos sorológicos __ 37

4. As drogas _ 39

Histórico _ 39

Principais drogas psicotrópicas __ 40

Tentativas de controle

O narcotráfico _ 44

Números do tráfico — 45

As organizações criminosas

Estratégias de controle do tráfico___ 46

5. Modelos matemáticos e seu uso em epidemiologia $\_$_

Novos conceitos em epidemiologia a partir dos modelos $\_57$

Abordagem quantitativa __ 61

6. Razão de Reprodutibilidade Basal $\left(R_{0}\right)$

Considerações gerais __ 66

Definição de $\mathrm{R}_{0}$ para microparasitas ___ 66

Histórico _ 67

Métodos de estimação de $\mathbf{R}_{\mathbf{0}}$

OBJETIVOS 83

7. Gerais 84

8. Específicos 85 
MÉTODOS 86

9. População alvo__ 87

Outras considerações acerca da cidade ___ 89

10. Amostra _ 95

Coleta de dados _ 96

Técnicas laboratoriais utilizadas _ـ 97

Análise matemática e estatística___ 97

11. Dedução de $R_{0}$ para "agulhas" __ 98

Modelos de infecções transmitidas por vetor ___ 98

AIDS em UDIs: quando a agulha pode ser um "vetor" __ 103

Heterogeneidades _ 110

RESULTADOS _ 118

12. Características da amostra 119

Padrões de injeção de drogas __ 120

Comportamento sexual ___ 121

Prevalência sorológica _ 122

Análise de fatores de risco

Análise univariada__ 126

Análise multivariada $\quad 129$

Análise matemática _ـ 130

Estimando $\mathrm{R}_{0}$ para uma comunidade de UDIs em Santos ___ 130

DISCUSSÃO _ 133

CONCLUSÕES 140

REFERÊNCIAS BIBLIOGRÁFICAS___ 143

ANEXOS 


\section{Resumo}

Com a finalidade de estudar a soroprevalência do Virus da Imunodeficiência Humana, $\boldsymbol{H I V}$, e infecções com transmissão relacionadas, entrevistamos e colhemos sangue de 197 usuários de drogas injetáveis, UDIs, amostrados através da metodologia de "bola de neve" (snow-balling), da cidade de Santos, São Paulo, Brasil. Nesta cidade a estimativa de UDIs, 10.000 indivíduos, compreende cerca de $2 \%$ de sua população. Soroprevalências de HIV, hepatites B e C, sífilis e HTLV (1 ou 2) foram obtidas e comparadas com 197 doadores de sangue pareados por idade e sexo.

As soroprevalências encontradas foram de $62 \%$ para HIV, 75\% para HCV, $75 \%$ para HBV, 34\% para sífilis, e $25 \%$ para o HTLV (1 e 2) entre os UDIs, comparado com $0 \% ; 2 \% ; 23 \% ; 12 \%$ e $1 \%$ entre os doadores do banco de sangue, respectivamente. Os fatores de risco para transmissões parenterais nesta comunidade de UDIs são mais importantes que para transmissão sexual, embora a última deva ser considerada quando se planejar estratégias de controle.

Além disso, estimamos a Razão de Reprodutibilidade Basal, $\boldsymbol{R}_{\boldsymbol{0}}$, para o HIV entre os UDIs. Usando um modelo clássico para infecções transmitidas por vetores de Macdonald adaptado para "agulhas", o valor de $\boldsymbol{R}_{\boldsymbol{0}}$ foi estimado em $\mathbf{2 8}$ e 98, considerando uma distribuição dos inóculos infectantes como homogênea ou heterogênea respectivamente . Esta estimativa foi baseada somente em parâmetros de transmissão parenteral nesta comunidade de UDIs. Usando este modelo a estimativa da soroprevalência do HIV no equilíbrio $(0,67)$ é bem próxima à soroprevalência observada $(0,62)$. 


\section{Summary}

In order to study the seroprevalence of HIV and infections with related transmission patterns, as hepatitis B and C, syphilis and HTLV (1 and 2), we interviewed and bled 197 IDUs, sampled by snow-balling and compared with 197 blood donors matched for age and sex, both groups from the city of Santos, Sao Paulo, Brazil.

Seroprevalences found were $62 \%$ for $\mathrm{HIV}, 75 \%$ for $\mathrm{HCV}, 75 \%$ for $\mathrm{HBV}$, $34 \%$ for syphilis and $25 \%$ for HTLV (1 or 2) among IDUs, which compare with $0.0 \%, 2 \%, 23 \%, 12 \%$, and $1 \%$ for blood donors, respectively.

The risk for parenterally transmitted infections in this IDUs community is higher than that for sexually transmitted one. We also estimated the Basic Reproduction Ratio, $\boldsymbol{R}_{\boldsymbol{0}}$, for HIV among IDUs. Using a model adapted from the classical Macdonald's model for vector-born infection, the $\boldsymbol{R}_{\boldsymbol{0}}$ resulted in $\mathbf{2 8}$ and $\mathbf{9 8}$, assuming an homogeneous or heterogeneous distribution of infective inoculae, respectively. This estimation was based only on parenteral transmission.

Using this model the expected equilibrium for HIV seroprevalence (0.67) is close to the observed seroprevalence $(0.62)$ 


\section{Convenções}

\section{Referências Bibliográficas:}

Foram organizadas em ordem alfabética por sobrenome do autor principal, seguidos do ano de publicação, sendo que entre colchetes em posição mais elevada e tamanho menor, aparece o número da referência. Apesar deste último poder ser dispensável, facilita em muito sua localização na lista.

Várias citações seguidas, recebem a ordenação cronológica de publicação e em seguida a ordem alfabética de autor.

Por exemplo: ..."por um único indivíduo em uma população inteiramente suscetível (Macdonald 1952[86]) e a soroprevalência de equilíbrio y* do HIV."

é vinculado à referência abaixo:

86. MACDONALD, G., The analysis of equilibrium in malária. Bull Trop Dis, v.49, p.813-28, 1952. 
Quando o autor é referido nominalmente no parágrafo, para evitar repetição, esta citação é feita sem o parenteses.

Por exemplo: ..." $\boldsymbol{R}_{\boldsymbol{0}}$ foi inicialmente utilizada em demografia ("net reprodution rate") por Richard Böckh, $1886^{[15]}$, em Berlin, para calcular..."

é vinculado à referência abaixo:

15. BöCKH, R.; Statistisches Jahrbuch der Stadt Berlin, Zwölfter Jahrgang Statistik des Jahres 1884, Berlin, P.Stankiewicz, p.301, 1986. apud DIETZ K, The estimation of the basic reproduction number for infectious diseases. Stat Meth Med Res, v.2, p.23, 1993.

\section{Principais abreviações}

Apesar da Síndrome da imunodeficiência adquirida receber a sigla em todos os países de língua latina de SIDA, iremos nos referir a ela como AIDS, do inglês (Adquired Immunodeficiency Syndrome), por ser no Brasil esta a maneira mais conhecida popularmente, bem como reconhecida nos meios técnicos e de comunicação. Pela mesma razão optamos pela sigla HIV (Human Immunodeficiency Virus) para nos referir ao vírus da imunodeficiência humana e HTLV 1 e 2 (Human $T$ Cell Limphotropic Virus) para os vírus associados com as leucemias de célula $\mathrm{T}$ e com as leucemias de célula pilosa, respectivamente.

Citaremos as siglas mais importantes utilizadas no texto e seus significados, como segue:

UDIs - usuários de drogas injetáveis,

$\boldsymbol{V H B}$ - vírus das hepatites B,

$\boldsymbol{V H C}$ - vírus das hepatites $\mathrm{C}$,

$\boldsymbol{A g H B s}$ - antígeno de superfície do vírus da hepatite B,

anti-HBc - anticorpo do "core" do vírus da hepatite B,

anti-HCV - anticorpo do vírus da hepatite C,

ELISA - teste laboratorial "Enzyme Linked Imunosorbent Assay", 
$\boldsymbol{F T A}$-abs - teste laboratorial "Fluorescent $\boldsymbol{T}$ reponemal Antigen-absorption test"

$\boldsymbol{R N s}$ - recém-nascidos,

$\boldsymbol{R}_{\boldsymbol{0}}$ - Razão de Reprodutibilidade Basal,

"agulhas"- referindo-se às seringas e agulhas,

$\boldsymbol{s} \boldsymbol{d}=$ desvio padrão,

$I C=$ intervalo de confiaça,

$\boldsymbol{O R}=$ odds ratio 


\section{Motivação}

E

m 1990, um surto de malária foi observado em um grupo de usuários de drogas injetáveis (UDIs), na cidade de Bauru, S.Paulo, Brasil (1993[12]). Este surto foi atribuído ao compartilhamento de seringas e agulhas, uma vez que a doença ocorreu somente entre os UDIs. É verdade que uma pequena quantidade de mosquitos Anopheles albitarsis, vetor de importância secundária na transmissão da malária $\left(1991^{[21]}\right)$, foi identificado na região, mas isto não foi suficiente para explicar o número de casos encontrados ou o fato de que somente os UDIs estivessem infectados.

Muitas das chamadas doenças transmitidas aos homens por vetores podem ser, eventualmente, adquiridas através da transfusão de sangue e seus derivados. Ocasionalmente, estas infecções podem acontecer pelo contato com materiais contaminados, e/ou uso de drogas injetáveis $\left(1990^{[47]}\right)$. De fato, vários surtos epidêmicos desta natureza têm ocorrido entre os UDIs, relatados na literatura $\left(1990^{[47]}\right)$.

A atual pandemia de AIDS é o mais dramático exemplo da importância desta forma de transmissão. Além das infecções ocorridas pelas transfusões de sangue e derivados, muito importantes num passado recente, são os UDIs que hoje aparecem como os principais alvos da transmissão do HIV, pela exposição parenteral por agulhas e/ou outros equipamentos contaminados, usados para injeção.

Observa-se que as infecções causadas pelo uso de drogas injetáveis, sem as precauções adequadas, estão se expandindo rapidamente, como conseqüência do aumento mundial do consumo de drogas e, em especial, desta alternativa parenteral. Mais de 60 países têm documentado a infecção pelo HIV entre pessoas que se injetam com drogas ilícitas, com um número adicional de 40 países, que relatam a prática de uso de drogas injetáveis (1994[114]). Como conseqüência, 
estes países têm populações de alto risco para a infecção do HIV, tanto do ponto de vista de contrair como de transmitir o vírus. Através destes grupos, o HIV propagase pela comunidade em que estão inseridos, através das vias de transmissão sexual e transplacentária, além da via parenteral. (1994[40]).

Nos países em desenvolvimento, a disseminação do vírus pela contaminação pelo uso de drogas injetáveis vem crescendo muito rapidamente (1990[82], 1993[118], 1993[135], 1993[126]). No caso específico do Brasil, acreditase que a principal causa deste aumento seja o fato de ser este uma importante, se não a mais importante rota do tráfico de cocaína dos países produtores, como Bolívia e Colômbia, para os países consumidores, na Europa e América do Norte ( 1992[99]).

A estrutura social das comunidades de UDIs promove o compartilhamento de agulhas e seringas, pois a ética de cooperação nos pequenos grupos é aplicada, também, ao uso compartilhado dos equipamentos para injetar drogas. A recusa do compartilhamento, sem uma razão social legítima, poderia provocar um questionamento do grupo sobre o indivíduo, acerca da confiança para outras ações $\left(1992^{[97]}\right)$. Além disto, razões como o limitado suprimento de agulhas e seringas, seu alto preço relativo, entre outras, fazem com que o compartilhamento deste equipamento ocorra entre indivíduos que se conhecem, os que pouco se conhecem, e mesmo entre os que são absolutamente desconhecidos, onde o uso da droga é o único elo comum entre eles. Vários fatores de risco têm sido associados com a soropositividade para o HIV em comunidades de UDIs: duração do uso de droga injetável, compartilhamento de agulhas e seringas, número de pessoas que participam do compartilhamento, quantidade de equipamentos disponíveis para injetar drogas, número médio de injeções e residência em área com alta prevalência do HIV (1987[32]).

Embora os dados epidemiológicos e laboratoriais atuais continuem a apoiar a hipótese de ausência de transmissão através de inseto vetor, $\left(1992^{[80]}\right)$ entre os UDIs o equipamento usado para injetar-se drogas (denominado a partir de agora de "agulhas") pode ser considerado como um "vetor inanimado". Fato curioso é que a palavra "dengue" é utilizada pelas prostitutas da região do porto da cidade de Santos, Brasil, referindo-se às usuárias de drogas injetáveis, o que talvez traga alguma referência intuitiva associando a febre do dengue, endêmica ali num passado não muito remoto, à função da agulha, atuando como vetor. 
A diferença básica entre o vetor biológico e as "agulhas" é que o vetor é um verdadeiro hospedeiro, isto é, exige uma fase obrigatória do ciclo biológico do parasita para desenvolver-se e reproduzir-se. Diferente do vetor verdadeiro, as "agulhas" são meramente carregadores do agente patogênico (1990[24]). Apesar destas diferenças, os conceitos desenvolvidos para as doenças transmitidas por vetores podem ser usados para a compreensão da dinâmica de transmissão destas doenças, quando adquiridas via transfusão, ou de particular interesse do contexto deste trabalho, via uso de droga injetável.

Este trabalho apresenta um novo uso de antigas idéias e conceitos relacionados com as infecções transmitidas pelo sangue, em particular uma adaptação dos modelos de transmissão da malária, desenvolvida por $1950^{[85-87]} \mathrm{e}$ que foi aplicada para os usuários de drogas injetáveis.

Muitas são as variáveis envolvidas na epidemia da AIDS e de outras doenças, que apresentam o mesmo padrão de transmissão. Neste trabalho, iremos analisar algumas delas, na intenção de localizá-las no contexto mundial e, assim, melhorar a compreensão de sua participação em um fenômeno que apresenta, como produto final, o indivíduo infectado.

Analisaremos inicialmente nos capítulos de 2 a 4, a epidemia da AIDS, onde serão feitas algumas considerações históricas acerca da infecção pelo HIV, de como esta epidemia vem-se comportando desde o seu início e suas repercussões. Serão, também, apresentadas algumas doenças como as retroviroses no homem, hepatites B e C, e sífilis, que apresentam formas de infecção de padrão semelhante ao HIV, tanto na característica parenteral como na sexual. Serão, também, abordados alguns aspectos relacionados com a imunidade, sorologia e as técnicas laboratoriais mais utilizadas.

Nos capítulos 5 e 6 seram analisados alguns aspectos relacionados com as drogas, narcotráfico e sua inserção nesta epidemia.

Nos capítulos 7, 8 e 9 serão analisados o conceito de "Basic Reproduction Ratio", $\boldsymbol{R}_{\boldsymbol{0}}$, aplicação dos modelos matemáticos dentro da epidemiologia e desenvolvimento de um modelo original para a estimativa de $\boldsymbol{R}_{\boldsymbol{0}}$ entre usuários de drogas injetáveis.

Os capítulos de 10 a 14 referem-se aos objetivos, métodos, resultados, discussões e finalmente as conclusões. 


\section{AIDS}

\section{Histórico}

E m 1981, foi publicado um trabalho com 5 casos de broncopneumonia por — Pneumocisti carynii em homens, jovens, homossexuais, com hábitos sexuais promíscuos, em Los Angeles, Califórnia (1981[27]).

A pneumonia causada pelo Pneumocystis carinii, um fungo que acomete geralmente animais, (coelhos, cachorros, gatos, ratos) onde a manifestação é razoavelmente branda. Este tipo especial de infecção pulmonar, eventualmente observada em seres humanos, é bastante grave, atingindo indivíduos que estejam com o sistema imunológico debilitado.

Nas investigações que se seguiram, observou-se uma associação bastante forte entre este tipo de infecção e indivíduos jovens, previamente saudáveis, homossexuais masculinos que passavam, a apresentar manifestações clínicas associadas a infecções oportunistas, com características de um organismo imunodeprimido.

Posteriormente também o sarcoma de Kaposi, um tumor cutâneo raro, passou a ser observado nestes indivíduos. Dessa forma, concluiu-se que as alterações observadas tratavam de manifestações sindrômicas de uma doença que comprometia o sistema imunológico do indivíduo.

Estes foram, então, os primeiros relatos sobre uma nova doença, que na época, não se poderia imaginar que apresentaria um comportamento pandêmico, e que colocaria, sob risco, grande parte da humanidade.

A trajetória das investigações na busca de um agente etiológico para esta síndrome passou por várias fases. 
A maioria dos indivíduos pertencia ao grupo de homossexuais masculinos, com hábitos sexuais promíscuos, daí surgirem associações que, posteriormente, foram descartadas:

- o efeito de imunodepressão causada por componentes do esperma sobre a mucosa do reto,

- o uso de drogas psicotrópicas e,

- o uso ou a conseqüência de um efeito adverso, de uma droga, derivada do nitrito, denominada de "poppers"1. Esta droga era muito utilizada, na pratica sexual, preferencialmente, em saunas freqüentadas por homossexuais, pelo seu efeito vasodilatador sobre pênis e mucosa anal, que promovia uma maior estimulação sexual.

Observou-se, no entanto, que a associação com a doença era muito mais importante quando levado em conta o número de relações sexuais do que com o uso da droga. Esta nova doença, pelas suas manifestações epidêmicas iniciais, foi denominada nos Estados Unidos, pelo Center for Disease Control and Prevention (CDC) de GRID (Gay Related Immuno Deficiency), isto é, uma doença relacionada com o homossexual.

Esta doença, no entanto, só começou a chamar a atenção das autoridades para a sua potencialidade destrutiva, quando surgiram os primeiros casos da síndrome, associados à transfusão de hemoderivados (1982[28]). Por estas razões, a partir deste ano, as evidências apontavam para etiologia viral, apoiadas nos seguintes pontos:

- para ocorrer infecção é necessário: contacto íntimo entre os indivíduos (sexual) ou transfusão com hemoderivados ou com sangue infectado (indivíduos hemofílicos, indivíduos politransfundidos);

- processos de filtração para preparação de hemoderivados não conseguem eliminar os vírus.

Em vista destes novos fatos, em 1984, recebe a denominação de AIDS (Adquired Immunodeficiency Syndrome).

${ }^{1}$ Denominação adotada pelo barulho que faziam ao destapar o frasco. 
Inicialmente foram pesquisados alguns vírus, como o da hepatite B e o citomegalovírus, pela alta prevalência em grupos com comportamento de risco para AIDS. Porém, o conhecimento prévio mostrou ser pouco provável que tais vírus pudessem apresentar as manifestações clínicas da síndrome.

Estudos de virologia, em veterinária (1975[49]), mostraram uma doença muito semelhante em felinos, causada por um vírus da família Retroviridae FeLV (vírus da leucemia felina). Esta família é bastante ampla e acomete vários animais da escala zoológica. Trata-se de um vírus RNA, que se utiliza de uma enzima, a Transcriptase Reversa, no seu mecanismo de mutiplicação.

Em 1980, no Instituto Nacional de Câncer dos EUA, o grupo chefiado por Robert Gallo, identificou em indivíduos com leucemia de células $\mathrm{T}$, um vírus, que foi responsabilizado pela linfadenopatia humana (1980[117]), denominado Human T Cell Linphotropic Vírus (HTLV posteriormente HTLV 1). A seguir, foi isolado de indivíduos com leucemia celular pilosa ("hairy cell leukemia"), outro vírus de constituição semelhante, porém com sorologia diferente, que se denominou HTLV 2 (1982[72]). Esses vírus foram chamados de transformadores por sua capacidade em induzir tumores através da transformação da célula, sem, no entretanto, destruí-la.

Posteriormente na Universidade de Harvard, associou-se a reação do soro de indivíduos com AIDS a células infectadas com retrovírus humanos, reforçando a hipótese de vínculo causal deste com a AIDS (1983[50]). No mesmo ano, o Instituto Pasteur de Paris, através da equipe chefiada por Luc Montaigner, identificou, utilizando o material proveniente de gânglios linfáticos de indivíduo com quadro clínico de AIDS Related Complex (ARC), um novo retrovírus, que chamaram de LAV (vírus associado à linfadenopatia) (1983[13]). No ano seguinte, nos EUA, comprovou-se o isolamento do retrovírus associado à AIDS, que chamaram HTLV III (1984[54]).

A identificação e cultura do vírus LAV/HTLV III permitiu a produção e desenvolvimento de reagentes biológicos em ampla escala possibilitando posteriormente, a realização de inquéritos sorológicos, diagnóstico laboratorial específico e o rastreamento em banco de sangue.

Entre 1984 e 86 Luc Montaigner e cols. descreveram um tropismo do vírus por linfócitos, que expressavam a proteína CD-4 em sua superfície. Esses linfócitos correspondem, em sua maioria, à sub-população com atividade 
auxiliadora no mecanismo imunológico. Isso facilitou associar-se a imunodepressão com a infecção (1988[56]).

Finalmente, em 1986, a Comissão de Taxonomia e Nomenclatura Internacional de Vírus resolveu adotar para esse vírus a denominação HIV - Vírus da Imunodeficiência Humana (1986[29]).

No mesmo ano, na França, a equipe de Luc Montaigner isolou outro vírus com características semelhantes ao HIV, em indivíduos portadores da síndrome (africanos e portugueses), cuja sorologia não apresentava reatividade ao teste antiHIV original conhecido. O vírus original passou a ser denominado HIV 1 e o vírus recém descoberto, HIV 2 (1986[35]).

Ainda com relação a estes vírus, há diversidade quanto à sua origem geográfica, pois considera-se o HIV 1 originário da África Central e o HIV 2 originário da África Ocidental. Do ponto de vista evolutivo, o HIV 2 é mais próximo dos retrovírus dos símios (SIV) do que o HIV 1. Embora a reatividade cruzada seja pequena entre os dois vírus (em média há $45 \%$ de semelhança na seqüência gênica), a organização dos genomas segue o mesmo padrão e pode ser descrita conjuntamente (1989[60]).

\section{Origem da epidemia}

Muito se tem especulado a respeito deste tema e várias são as teorias que surgiram, e vêm surgindo, para tentar explicar esta epidemia. Muitas evidências levam para a hipótese de que o vírus proveniente do macaco tenha infectado a espécie humana (1989[60]).

Um vírus muito similar ao HIV foi encontrado em macacos verdes africanos, Cercopithecus aethiops, espécie comum na África Central, atingindo uma prevalência de 50\% dos macacos testados (1989[60]). Estes animais, no entanto, permanecem saudáveis, mesmo na presença do vírus. Tais vírus, quando inoculados em outros animais, são capazes de produzir uma doença muito parecida com a AIDS. Aparentemente, a resposta imunológica ao patógeno varia entre as diferentes espécies, o que faz supor graus variáveis de adaptação da espécie hospedeira ao agente infectante. Em algumas espécies, como no macaco, este tipo adaptação é bem sucedida, isto é, o vírus consegue infectar e, ao mesmo tempo, preservar o hospedeiro, proporcionando a sobrevivência de ambos. 
Em certas regiões da África, onde a infecção pelo HIV no homem é bastante freqüênte, existem evidências que poderiam facilitar a transmissão do vírus, por propiciar um maior contato entre o homem e o macaco, são elas:

- macacos são usados como animais domésticos;

- acidentes por mordedura de macacos são bastante freqüentes;

- a carne de macacos é utilizada como alimento;

- rituais envolvendo a injeção de sangue de macacos. 1973 .

*+[75] publicou os resultados de um estudo antropológico de práticas sexuais dos indivíduos moradores na área dos Grandes Lagos (África). "...para estimular um homem ou uma mulher e induzí-los a uma intensa atividade sexual, o sangue de macacos machos (para os homens) ou de macacas (para as mulheres) era inoculado diretamente no púbis, nas coxas e dorso...."

Talvez mutações virais permitiram que tais virus cruzassem a barreira das espécies, pois mutações virais são usualmente muito "tóxicas" para seus novos hospedeiros (1989[60]), isto é, quanto mais primitivo é o vírus, mais agressivo ele se torna para o hospedeiro. Na evolução das espécies existe um grande esforço para adaptar-se a novas situações: os que melhor se adaptam, sobrevivem; o que se procura atingir é uma simbiose "perfeita", onde ambos permaneçam vivos na interação.

Alguns autores acreditam que, biologicamente, o homem e o macaco são muito diferentes para que possa existir este tipo de transmissão, outros apontam a semelhança de alguns vírus de macaco com o HIV (1987 [107], 1987 [74]).

É muito delicado, porém, apontar locais ou povos que pudessem ter dado origem a uma epidemia desta natureza, devido ao alto grau de discriminação que acompanha qualquer afirmativa deste tipo e que poderia deixar de lado o sentido técnico-científico, para reforçar diferenças sócio-políticas.

Inicialmente houve um direcionamento das pesquisas quanto à infecção estar associada ao Haiti, pelo fato de existirem vários casos da síndrome em homossexuais americanos que tiveram férias nesta região. Análises posteriores, avaliando os fatores de risco para a infecção pelo HIV, não observaram ligação da infecção com os haitianos, embora, entre eles, a infecção estivesse fortemente 
associada à utilização, inclusive pelas instituições de saúde, de maneira inapropriada, de materiais do tipo agulhas e seringas, entre outros, contaminados (1989[60]).

No entanto, em estudos mais recentes e melhor fundamentados (1989[60]), apontam o continente africano como sendo o local onde provavelmente a epidemia possa ter se iniciado, por várias razões:

- as sorotecas humanas mais antigas da década de 50-60, originadas da África Central, possuiam sorologia positiva para o HIV, em contraste com testes negativos de outras regiões;

- a grande diversidade de retrovírus em primatas africanos;

- estudos clínicos e epidemiológicos demonstram que os primeiros casos de AIDS podem ter ocorrido na África, pois a disseminação da infecção encontra-se em estágio mais avançado na população geral desse continente.

\section{O agente}

\section{Retrovírus humanos}

São vírus cujo ácido nucleico é o RNA e que utilizam a enzima Transcriptase reversa para fazer a transcrição do ácido nucleico, no sentido inverso do habitual, durante a sua multiplicação dentro da célula infectada (1988[66]).

Os retrovírus constituem uma família enorme de vírus, que causam doenças em animais de todos os níveis da escala biológica. Eram pouco conhecidos em medicina humana.

A capacidade de mutação destes vírus é grande. No caso de HIV é de, aproximadamente, 5 vezes a do vírus da gripe (1989[60]). No processo de multiplicação dos retrovírus, no qual há a "transcrição reversa" dos ácidos nucleicos, ocorre relativamente grande número de erros. Após alguns ciclos em cultura, 3\% das bases são alteradas. Os retrovírus sofrem muitas mutações, que os tornam com características antigênicas diferentes do vírus original, sendo difícil encontrar dois retrovírus idênticos. No entanto, de forma geral, a reatividade 
cruzada é grande entre eles, o que torna possível, por exemplo, o emprego de uma variedade de vírus para o diagnóstico de infecção por HIV ( 1988[66]).

\section{Características do agente}

É um vírus muito frágil quando exposto ao meio ambiente. Porém, quando no interior das células, linfócitos e macrófagos por exemplo, torna-se bastante resistente (1988[66]).

O vírus HIV apresenta simetria icosaédrica, medindo de 100 a $200 \mathrm{~nm}$. Apresenta um envelope com uma superfície externa, uma interna e uma porção central, denominada "core" viral (figura 1).

Figura 1. Esquema do HIV²

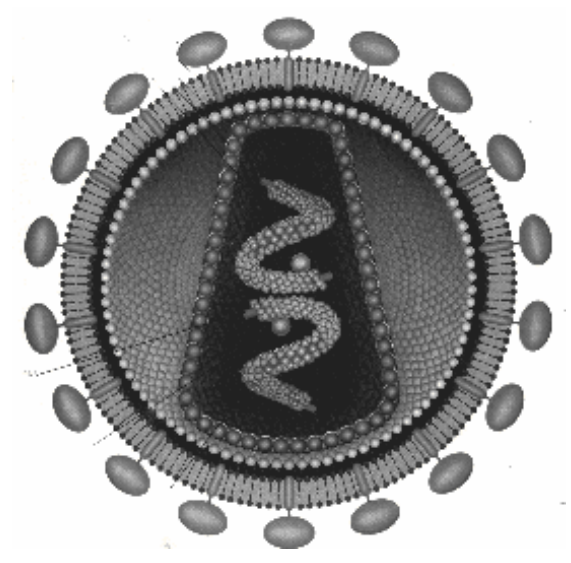

\section{Envelope viral}

\section{Superficie externa:}

Na superfície externa dos vírus HIV há espículas de natureza glicoproteica, que fazem saliência na parte externa e penetram no interior da partícula viral. Esta característica da superfície é a responsável pela ligação com o linfócito auxiliador, (T4) no processo imunológico ( 1988[66]).

No HIV 1, a porção externa da espícula é chamada gp 120 e a porção interna da espícula, gp 41. No HIV 2, a porção externa é chamada gp140 e a porção interna, gp36. Esta denominações são apoiadas na sua constituição química

${ }^{2}$ Esquema obtido da Scientific American, página.43, october, 1988. 
e em seus pesos moleculares, por exemplo, a glicoproteína, com peso molecular de 120.000 daltons, é chamada gp120 ( $1988^{[66]}$ ).

\section{Superficie interna}

Apresenta uma estrutura eletrondensa alongada, responsável pela inoculação do material genético viral no interior da célula.

\section{"Core" viral}

Na região central do vírus, há uma estrutura cilíndrica com base maior que o ápice, chamada "core". Nela detecta-se, no HIV 1, principalmente a proteína p24 e, no HIV 2, a proteína p26. Outras proteínas estão presentes, algumas estruturais e outras com atividade enzimática ( 1988[66]).

Há grande distinção entre as glicoproteínas de superfície dos dois vírus, porém as proteínas do "core" têm um certo grau de semelhança e, pode haver reatividade cruzada entre elas $(1988[51])$.

Proteínas estruturais são glicoproteínas de superfície, proteínas centrais e aquelas com atividade na replicação viral. Essas proteínas são produzidas em grande quantidade, induzindo o organismo a produzir anticorpos, que passam a ser detectáveis.

Proteínas reguladoras, modulam a expressão das proteínas estruturais, mantendo o vírus sob forma latente, ou induzindo sua maior ou menor expressão. Sua detecção não é uniforme, mas é muito importante por diferenciar o HIV 1 do HIV 2 e auxiliar na compreensão da dinâmica da produção destes anticorpos, ao longo da história natural da doença. Estas proteínas são produzidas em pequena quantidade e, normalmente, não se detectam anticorpos contra elas ( 1988[66]).

\section{Genoma}

No genoma, onde se tem a estrutura genética viral, foram descritos genes estruturais e reguladores.

\section{Genes estruturais}

São os genes responsáveis pela codificação das proteínas que participam da estrutura viral. São eles: o ENV (envelope) que codifica a gp de superfície; o GAG (gene de antígeno de grupo), que codifica a proteína do "core"; o 
POL (polimerase), que codifica a Transcriptase Reversa e as endonucleases, enzimas que fazem a multiplicação do vírus ( 1988[66]).

\section{Genes reguladores}

São os que codificam as proteínas com atividade reguladora da síntese proteica e, portanto, da replicação viral, são eles ( 1988[66]):

- $\quad$ TAT (fator de transativação) ativa a produção de todas as proteínas virais, tanto as estruturais como as reguladoras. Quando estimulada pelo encontro com um antígeno, causam explosão de replicação viral nos linfócitos T4.

- REV (fator regulador da expressão proteica), quando estimulado, leva o vírus a produzir, seletivamente, componentes estruturais e, na ausência deste estímulo, síntese de proteínas reguladoras.

- $\quad$ NEF (fator de negativação) codifica a proteína que inibe a produção de todas as proteínas virais, tanto as estruturais como as reguladoras. Pode ser o responsável pela manutenção de infecção latente, se no início da infecção houver um acúmulo desta proteína.

- VIF (fator de virulência ou infectividade) codifica uma proteína que é encontrada no citoplasma de células infectadas, no fluido que as envolve e em algumas partículas virais livres. Cepas de HIV, que através de mutações perderam este gene, produzem vírus aparentemente normais, mas que não infectam células eficientemente.

- VPR, com função não determinada.

- VPU existente apenas no HIV 2 e também sem função definida. 


\section{Infecção pelo HIV na espécie humana}

Após penetrar no organismo humano, os HIVs devem ligar-se a células que tenham receptores específicos para elas, que são os CD4. Este receptor é uma proteína que está presente em células do Sistema Fagocítico-Mononuclear.

A ligação vírus-célula é essencial para a sobrevivência do vírus e ocorre da seguinte maneira ( 1988[66]):

1. O vírus liga-se através de suas gp de superfície (receptor viral), ao CD4 da célula (receptor celular);

2. Ocorre fusão dos envelopes viral e celular (o envelope viral é de constituição lipo-proteica semelhante à membrana celular) e o genoma viral (RNA) é internalizado, isto é, alcança o interior da célula.

3. O genoma viral vai ser transcrito em DNA, através da Transcriptase reversa e, a seguir, integrar-se ao genoma celular, podendo ficar latente ou induzir a produção de proteínas virais.

Observações:

- Em situações normais, no momento em que o linfócito T4 é ativado, por exemplo, pela presença de qualquer antígeno estranho, o genoma celular é requisitado para coordenar a produção de proteínas. No caso desta célula estar contaminada pelo HIV, teremos o genoma viral integrado ao celular, podendo ocorrer uma "explosão" de produção de partículas virais. Portanto, a estimulação do Sistema Imune, que deveria resultar numa defesa e oferecer proteção ao indivíduo, no caso dos pacientes infectados pelo vírus HIV, leva à produção de mais vírus.

- Algumas células, como os linfócitos T4, têm muitos receptores CD4 na sua superfície, o que as tornam alvo fácil para os vírus HIV. Nessas células, o vírus penetra, multiplica-se e é liberado.

- Outros tipos de células, como os macrófagos e células do Sistema Nervoso Central, não apresentam receptores CD4 em sua superfície, porém podem ser infectadas pelo HIV. Diferente dos linfócitos, não há efeito citopático nos macrófagos. Estes poderiam, então, ser causa de infecção latente, funcionando como reservatório de vírus. 
- Quando o indivíduo infectado apresenta-se assintomático, o número de linfócitos T4 circulantes é pequeno, cerca de 1\% do total. No entanto, nos linfonodos observa-se intensa replicação viral durante este período, com progressiva destruição de suas arquiteturas e funções (1995[89]).

\section{Mecanismos pelos quais os HIVs causam imunossupressão}

\section{Resposta imune}

\section{Normal}

$\mathrm{Na}$ resposta imune, o antígeno que é fagocitado pelo macrófago é processado por ele, sendo em seguida "apresentado" ao linfócito T4, junto aos antígenos de histocompatibilidade, que o reconhece como estranho. O linfócito T4 é ativado por este contato célula-célula com o macrófago e através de citocinas como a interleucina 1 (IL-1), interleucina 2 (IL-2) liberadas por este (, 1988[120]).

O linfócito T4 vai produzir, a IL-2 e o Interferon gama que ativam o sitema imune celular e IL-4, IL-5 e IL-10 que ativam a imunidade humoral. Porisso, o linfócito T4 é chamado de "regente da orquestra imunológica" (, 1988[120]).

\section{Na infecção pelo HIV}

Os linfocitos T4 estimulados, por possuírem grande quantidade de receptores CD4 em sua superfície, ficam mais susceptíveis à infecção, pois vírus ligam-se exatamente nestes receptores (, 1988[120]).

Estes linfócitos T4, passam a ser destruídos no transcorrer da infecção, devido ao efeito citopático viral, ou por mecanismos indiretos de destruição de células induzidos pelo vírus ocorrendo uma depleção deste tipo de célula.

Normalmente observa-se uma relação de 2:1 entre o número de linfócitos auxiliadores (T4) e linfócitos supressores (T8). Na infecção pelo HIV, esta relação apresenta uma tendência a inversão, à medida em que a defesa imune do organismo se deteriora, observa-se uma queda relativa e absoluta do número de linfócitos T4 (, 1988[120]).

Além de alterar o Sistema Imunológico, interferindo nas funções dos macrofagos e linfócitos T, B, células NK ("natural killer"), o HIV ataca também o Sistema Nervoso Central, em nível de cérebro e coluna espinal, produzindo 
infecções com manifestações clínicas, tais como depressão, enxaqueca, desorientação, paralisias e até demência (, 1988[120]).

\section{Transmissão do HIV}

A transmissão do HIV ocorre através do contato sexual, da exposição parenteral ao sangue e seus derivados e da mãe para o feto, durante o período gravídico-puerperal (transmissão vertical) ou pelo leite materno. No momento, não existem evidências de outras formas de transmissão (1995[89]).

\section{Presença do vírus}

O HIV já foi isolado do sangue, líquido seminal, secreção vaginal em grandes concentrações e, também, na saliva, lágrima, urina, líquor e leite materno, em concentrações menores (1995[89]).

\section{Aspectos clínicos}

Desde sua identificação como uma síndrome que acometia pacientes previamente saudáveis, que apresentavam, até então, raras infecções oportunistas graves, associadas a uma imunodeficiência celular inexplicada (1981[27]), os conhecimentos acerca da AIDS passaram a exigir conceitos mais refinados.

A síndrome é composta de estágios, passando por um período de incubação, que é caracterizado como a pré AIDS ou "AIDS related complex" (ARC) até atingir o estado de AIDS doença, quando passa a ser acometido por outras infecções, principalmente as oportunistas. Existe um esforço para se caracterizar o momento em que um indivíduo infectado pelo HIV transpõe a barreira ARC para AIDS doença. Esta caracterização é cercada de grande importância, tanto clínica como epidemiológica, por orientar as ações terapêuticas e colaborar nas avaliações epidemiológicas.

O CDC propõe um sistema de classificação de infecções causadas pelo HIV, onde objetiva caracterizar as formas de manifestação da infecção e da doença. Esta classificação proposta sugere uma divisão por faixa etária: os menores de 13 anos - AIDS pediátrico - (1992[30]), os maiores ou igual a 13 anos 
- AIDS em adolecentes e adultos -, apoiada nas características da infecção, nas manifestações clínicas e condições imunológicas (1994[31]).

A AIDS doença, de maneira geral, manifesta-se clinicamente como um quadro sindrômico de emagrecimento, febre, diarréia persistente, queda do estado geral associado à infecções oportunistas.

Nos indivíduos contaminados via sexual a doença manifesta-se, além deste estado sindrômico geral, através das infecções oportunistas, neurológicas e sarcoma de Kaposi. Nos indivíduos que se contaminaram via parenteral, que é o caso dos UDIs, hemofílicos e pós tranfusionais, costuma existir outras infecções associadas. As endocardites e as infecções bacterianas não são raras e a tuberculose passa a ser bastante recorrente. $\mathrm{O}$ aumento das doenças ginecológicas, infecções inflamatórias pélvicas e aumento do câncer cervical que ocorre atualmente nos USA, atingem em mais de $80 \%$ as mulheres UDIs ou parceiras de UDIs (1994[40]).

\section{Aspectos laboratoriais}

\section{Apectos gerais}

Após o isolamento do HIV (1983[13] ), os retrovírus passaram a ter muita importância para a medicina humana, tornando-se muito conhecidos no meio científico, além de ter sua popularidade difundida através da "midia". Menos de dois anos depois, muitos países, desenvolveram e implantaram testes para o diagnóstico sorológico. As triagens sorológicas nos bancos de sangue melhoraram bastante, identificando contaminação tanto pelo HIV 1 como pelo HIV 2, o que fez com que esta via de transmissão alcançasse níveis bastante baixos. Os outros retrovirus, HTLV 1 e 2, estão também sendo reavaliados e espera-se que essa triagem também possa ser extendida mundialmente para eles (1989[60]).

Na maioria dos países, incluindo o Brasil, a prevalência da infecção pelo HIV na população geral ainda é baixa, embora esteja aumentando rapidamente nos últimos anos, como já mencionado.

As indicações clínicas do teste sorológico anti-HIV tornam-se cada vez mais amplas, e hoje este teste já faz parte de rotinas de serviços, não só 
relacionados com a triagem dos bancos de sangue, mas também com os pré-natais, pré-operatórios, e os específicos de investigação diagnóstica, entre outros.

No caso específico da triagem de doadores nos bancos de sangue, optou-se por testes de alta sensibilidade, embora pudessem apresentar reações falsopositivas. O resultado negativo é altamente confiável (1995[89]). Apesar da população analisada ser ainda de baixa prevalência para a infecção, a gravidade da doença e o seu modo de transmissão justificam os descartes de material falsopositivo. Para caracterização de indivíduos contaminados exige-se a aplicação de testes confirmatórios (1995[89]).

\section{Aspectos sorológicos}

Vários são os exames laboratoriais desenvolvidos para detecção da infecção pelo HIV. Estes exames podem utilizar tanto métodos diretos (detecção do agente) como indiretos (detecção do anticorpo contra ele). Através destes estudos, algumas conclusões puderam ser tiradas:

- A doença apresenta um período de incubação variável, que além do componente individual, está associado com os mecanismos de aquisição da infecção. É observado na transmissão parenteral, uma tendência ao encurtamento deste período (1994[40]).

- O sistema imunológico após o contato com o vírus, produz anticorpos geralmente dirigidos contra suas proteínas estruturais, em um tempo que varia de 15 dias a 6 meses. Antígenos virais circulantes, foram detectados até 4 dias após a infecção. O período que vai do momento da infecção até reação sorológica positiva, é chamado de janela imunológica. Neste período o indivíduo possui o vírus, portanto é infectante, e não possui marcadores sorológicos detectáveis (1995[89]).

- Após a fase da janela imunológica, vem a fase em que o indíviduo, apesar de possuir marcadores sorológicos, não apresenta a doença manifesta clinicamente. Estes indivíduos são chamados portadores assintomáticos. A partir do momento que surge a primeira manifestação clínica, passa então a ser caracterizado como AIDS doença (1995[89]).

- Do ponto de vista epidemiológico, os portadores assintomáticos, constituem-se na fonte de transmissão mais importante da epidemia. 


\section{Diagnóstico sorológico da infecção pelo HIV}

Dentre as principais metodologias utilizadas para detecção de anticorpos dirigidos contra o HIV, temos:

- ensaio imunoenzimático (ELISA - Enzyme Linked Imunosorbent Assay);

- teste de imunoeletrotransferência (WESTERN BLOT)

- reação de Imunofluorescência Indireta;

- reação de aglutinação com partículas de Látex,

- ensaio de radioimunoprecipitação (RIPA)

- produção induzida de anticorpos anti-HIV-1 "in vitro" (IVIAP).

Os testes mais utilizados e aceitos mundialmente pela sua praticidade e operacionalidade são:

\section{ELISA}

O teste ELISA apresenta alta sensibilidade e alta especificidade. É uma reação simples, rápida, com facilidade para automação, de custo acessível, e que por estas razões é o escolhido para ser usado como teste para rastreamento e inquéritos epidemiológicos (1995[89]). 
A técnica $\boldsymbol{E} \boldsymbol{L I S \boldsymbol { A } A}$ baseia-se na fixação de antígenos virais a uma fase sólida, a qual é acrescentado o soro ou plasma. Os anticorpos quando presentes, ligam-se ao antígeno fixado durante um período de incubação. Lavagens sucessivas removerão o material que não foi fixado, acrescenta-se então o conjugado, constituido de anticorpos marcados com uma enzima, por exemplo a peroxidase, dirigidos contra os anticorpos humanos. Após a incubação, haverá a ligação dos anticorpos com seus antígenos (os anticorpos humanos que se ligaram aos antígenos fixados). A seguir é adicionado uma solução contendo o substrato da enzima, no caso o peróxido, e o cromógeno, no caso a ortodifenildiamina - $\boldsymbol{O P D}$. Existe então uma reação da enzima peroxidase com o peróxido causando a liberação de oxigênio. A $\boldsymbol{O P D}$ na presença de oxigênio oxida-se e se torna colorida, mudando a cor da solução. Após um período padronizado, bloqueia-se a reação com ácido sulfúrico, e submete-se esta solução à leitura no espectofotômetro. A intensidade da cor é diretamente proporcional à quantidade de anticorpos presentes que se ligaram ao antígeno

Esta técnica para detecção de anticorpos anti-HIV vem sendo aperfeiçoada, tendo passado por etapas que foram denominadas gerações, assim discriminadas (1995[89]):

- teste de primeira geração - utiliza como antígenos as proteínas obtidas do lisado viral;

- teste de segunda geração - utiliza como antígenos as proteínas virais obtidas com técnicas de biologia molecular;

- teste de terceira geração - utiliza como antígenos, proteínas sintetizadas artificialmente.

\section{Western Blot}

Também conhecido como ensaio de imunoeletrotransferência, é utilizado mundialmente como teste de confirmação diagnóstica da AIDS.

Nesta técnica, as proteínas virais são separadas através de migração em gel, com base em sua carga elétrica e seu peso molecular. A seguir estas proteínas são transferidas para uma folha de papel de nitrocelulose onde ocorrerá a reação com os anticorpos eventualmente presentes no soro. Devido ao problema de reações 
inespecíficas, foram adotados alguns critérios para interpretação dos resultados (1979[136]).

$\mathrm{Na}$ prática, associa-se pelo menos os dois métodos aqui descritos para o laudo definitivo, dado o risco de reações cruzadas que poderia levar a um falso diagnóstico (1995[89]).

Existem situações em que seria interessante diferenciar a infecção pelos diferentes vírus HIV 1, HIV 2 ou coinfecção, apesar do assunto ainda ser controverso em relação a existência de diferentes evoluções clínicas. A sua identificação apresenta maior aplicação em estudos epidemiológicos (1995[89]).

Limitações do teste:

- O teste de primeira geração serve como triagem de uma população geral (banco de sangue), pela sua alta sensibilidade, porém não é muito aconselhável para o diagnóstico clínico pelo fato de ocorrer um número significativo de resultados falsos-positivos.

- Os testes de segunda e terceira gerações são mais indicados para uso em laboratório clínico, onde é exigida uma maior segurança para o laudo positivo, embora necessite confirmação.

\section{Aspectos gerais da pandemia e seus números}

Desde os primeiros casos relatados da doença, em 1981, a AIDS assume, hoje, o papel de um dos principais problemas de saúde no mundo. Estima-se que cerca de 3 milhões de indivíduos tenham sido afetados pela doença e que 15 milhões entre homens, mulheres e crianças já tenham sido infectados pelo HIV (1989[110]).

Projeções mais otimistas sobre a epidemia estimam que 25 a 30 milhões de pessoas estarão infectadas no ano 2000 , sendo que $20 \%$ destas infecções deverão atingir crianças e que $90 \%$ dos infectados pertencerão aos países em desenvolvimento (1991[112]).

A magnitude do avanço da epidemia e suas conseqüências podem ser hoje observadas em países da África, como Uganda, por exemplo, participando com a maior prevalência de indivíduos infectados pelo HIV na população geral, que é de 
4,9\%, ou mesmo na província de Bas-Zaire, no Zaire, onde a prevalência de infectados, nas grandes cidades, chega a atingir 7,6\% da população (1992[90]).

Sob o ponto de vista do modo de transmissão, a via sexual, com características heterossexuais, participa atualmente no mundo com $71 \%$ das infecções pelo HIV, sendo seguida pela transmissão sexual, com características homo e bisexuais com 15\%, dos UDI com $7 \%$ e das transfusões de sangue e derivados com $5 \%(1992[90])$.

Nas Américas, foram notificados até janeiro de 1995, 526.682 casos de AIDS. Acredita-se, no entanto, que este valor esteja em torno de 1.100 .000 casos, acumulados com aproximadamente 4,5 milhões de indivíduos infectados $(1995[109])$.

Estas estimativas são feitas através de correções dos dados obtidos das notificações. Estes dados estão sujeitos a vários tipos de erros, que ocorrem, basicamente, pelo atraso na notificação, dificuldades de diagnóstico da doença e subnotificação.

\section{Impacto social}

Analisando a história natural da doença, temos quatro pontos a considerar para avaliar seu impacto social (1994[115]):

- o período de incubação é da ordem de 10 anos (mediana),

- uma vez doente, a sobrevida é de 3 anos, em média,

- a letalidade é praticamente de $100 \% \mathrm{e}$

- o grupo etário mais atingido encontra-se na faixa socioeconômica mais produtiva.

O longo período de incubação da infecção traz, como conseqüência, um acúmulo no número de indivíduos infectados. No estágio de infectado, o indivíduo é infectante, apesar de se apresentar clinicamente sadio. Por essa característica, este estágio representa uma importante forma de disseminação do vírus, pois o indivíduo infectante, não mudando seu comportamento, acaba por participar, consciente ou inconscientemente, da disseminação do vírus na comunidade. 
O estágio de doença, pela característica de manifestar-se principalmente pelas infecções oportunistas que proporciona, contribui com um aumento significativo da prevalência destas infecções na comunidade. Por exemplo, o aumento da incidência de tuberculose pulmonar ativa, em pessoas infectadas pelo HIV, trouxe para alguns países, como o EUA, um novo encontro com uma doença, que até então, já estava controlada. Em alguns locais, esta infecção oportunista é a mais comum entre os enfermos de AIDS, chegando a atingir, neste grupo, uma prevalência de até 25\% (1994[115]).

Nos últimos anos, o grande sucesso obtido acerca do conhecimento da AIDS não foi acompanhado em igual proporção pela terapêutica, que, apesar de ter conseguido aumentar a sobrevida, não consegue evitar a sua evolução fatal. Este é um fator importante que contribui de forma negativa para decisões políticas, em escala mundial, nas aplicações de recursos, onde por vezes os argumentos favoráveis acabam por restringir-se aos aspectos éticos e humanitários do problema.

Apesar da dificuldade na obtenção de dados, estima-se que atualmente nos EUA o custo de um paciente com AIDS, em nível hospitalar, esteja ao redor de 32.000 dólares/paciente/ano e, em nível ambulatorial, o acompanhamento de um paciente HIV positivo, em torno de 5.000 dólares/paciente/ano. No Brasil, o custo hospitalar do paciente com AIDS é de 18.000 dólares/paciente/ano (1992[90]). Estes valores têm grande variabilidade, dependendo do local e época em que estejam sendo avaliados. No início da epidemia, por exemplo, o custo hospitalar deste mesmo paciente, nos EUA, estava em torno de 150.000 dólares/paciente/ano. Apesar de todas estas variações, dá para se ter uma idéia da pesada carga social gerada por esta epidemia, que aumenta em magnitude quando envolve países em desenvolvimento, os quais nem sequer conseguiram equacionar os graves problemas de saúde, já existentes em seu contexto.

A característica da epidemia de acometer principalmente os indivíduos na idade produtiva (entre 20 e 40 anos de idade), reflete-se, economicamente, na comunidade em que ele está inserido, de duas formas: nos custos relativos à doença propriamente dita e na retirada do indivíduo do setor produtivo desta comunidade.

É de se esperar que esta faixa etária, por estar também relacionada com a fertilidade, ao infectar as mulheres, aumentará a quantidade de infecções em 
crianças. Uma previsão da UNICEF é de que na África, para o ano 2000, haverá aproximadamente 600.000 mulheres que morrerão vítimas da AIDS, deixando atrás de si em torno de 5.500.000 orfãos, sendo uma quantidade significativa destes infectados pelo HIV (1991[106]). A epidemia deixa de ser um problema restrito, que afeta somente a área da saúde, para assumir proporções que se estendem para todos os setores da sociedade, desde o social, político até o econômico. Em algumas regiões da África, caso algum tipo de intervenção efetiva não seja feita, a AIDS chega a ameaçar a sobrevivência de comunidades inteiras (1991[106]).

A Ásia, que abriga $50 \%$ da população mundial e que tem o vírus introduzido na população em época relativamente recente (meados da decada de 80), participou, até junho de 1993, com 1\% dos casos notificados no mundo. Um ano após, já participa com 6\% destas notificações. Estes dados indicam um grande potencial de crescimento da epidemia na região (1995[109]). Este quadro exige grande atenção ao problema e cria a necessidade de mudanças comportamentais profundas para controlar este avanço. Baseados em dados como estes, a previsão da epidemia para este continente não é nada otimista (1994[95]).

\section{Perfil epidemiológico}

É muito complexo definir o perfil epidemiológico da AIDS, por ser uma doença dinâmica e que apresenta uma variabilidade muito grande de comportamento nas populações que acomete. Desde a tentativa da OMS de traçar um perfil para a epidemia, seu comportamento vem mudando e, com isso, criando dificuldades na sua aplicação. A importância desta classificação, apesar de já ter desempenhado papel mais destacado na década de 80 que hoje, é que ajuda a fornecer uma idéia da dinâmica da transmissão do HIV pelo mundo.

A OMS definiu três padrões epidemiológicos para classificar a infecção pelo HIV (1989[110]), apoiando-se em dois critérios: na forma da infecção e na sua incidência. Apesar de serem reconhecidos dois sorotipos do HIV (1 e 2), o aspecto biológico do vírus não foi incluído como um critério. Apesar do HIV 1 ser hoje mais estudado e, conseqüentemente, mais conhecido, não foi observada uma diferença muito grande no que diz respeito à patogenicidade e transmissibilidade das duas formas: a forma de transmissão e a doença desenvolvida basicamente são semelhantes. O HIV 1 é a forma mais disseminada em todo o mundo, enquanto que 
o HIV 2 tem sua disseminação mais limitada, tendo importância epidêmica em algumas regiões na África Ocidental.

Pelo padrão I, observado principalmente na América do Norte, do Sul e Oceania, onde exite uma intensa disseminação do vírus, principalmente associada ao homo/bissexualismo masculino e usuários de drogas de ambos os sexos. A doença atinge muito mais homens que mulheres. Esta diferença entre os sexos, que era de 15:1, está diminuindo com o passar do tempo, atingindo hoje valores mais equilibrados ao redor de 6:1 (1994[115]). A incidência em nível populacional é baixa, quando comparada com os outros perfis (menor que 1\%).

Pelo padrão II, observado especialmentre na África e algumas áreas do Caribe, a transmissão se dá principalmente pelo contacto sexual, na modalidade heterossexual; a infecção acomete proporções semelhantes de homens e mulheres, e como consequência, o número de crianças acometidas é elevado decorrente principalmente da transmissão vertical.

Pelo padrão III, observado principalmente nas áreas do Sudeste da Ásia, a doença é considerada de importação, isto é, os indivíduos adquirem a doença no exterior, em regiões de padrão I ou II ou com os estrangeiros, que se deslocam para lá. Com um início mais recente (metade da decada de 80), sua prevalência é relativamente baixa, porém cresce de importância a transmissão através de UDI e heterossexual.

Posteriormente, foi definido um padrão intermediário Padrão I/II; engloba países do padrão I, que nos últimos anos vêm apresentando uma mudança da forma de transmissão, aparecendo uma significativa proporção de infecção heterossexual.

Com relação ao HIV 2, após sua descrição, em 1986, em pacientes com passagem na região ocidental da África, passou-se ao mapeamento das áreas acometidas pelo vírus, que foram bastante restritas, com ampla disseminação no oeste da África e, mais esporadicamente, em regiões que, de alguma forma, mantiveram contato com estas populações.

Desde o início da epidemia, observou-se uma mudança da participação dos casos, segundo a forma de transmissão. Se no início os casos eram predominantemente de transmissão homossexual masculina e bissexual, atualmente a transmissão heterossexual já passa a ser a mais importante, contribuindo com cerca de $70 \%$ dos casos (1991[111]). O aumento do número de 
infecções entre as mulheres traz, como conseqüência, um aumento de infectados entre as crianças.

Este comportamento dinâmico observado na AIDS, que apresenta variações temporal, local e individual, cria a necessidade de se obter um instrumento mais adequado para analisar a epidemia. O objetivo de se definir em padrões é o de conseguir desenvolver uma estrutura suficientemente sensível, a ponto de ser capaz de fornecer respostas acerca do fenômeno estudado - (a epidemia de AIDS), padrões esses que contemplem os pontos comuns, individual e populacional e que consigam incorporar mudanças, demonstrar a variabilidade e evoluções locais, nacionais e regionais, sem perder de vista a visão global da epidemia e dos avanços relacionados com seu controle.

Uma vez que a definição destes perfis epidemiológicos começa a se mostrar limitada na atual fase, algumas propostas de mudança são sugeridas, como, por exemplo, o do agrupamento das regiões afetadas em 10 diferentes categorias. Estas categorias são classificadas de acordo com três fatores: epidemiológicos, operacionais e sociais. Dentre os fatores epidemiológicos estariam os principais modos de transmissão, proporção de casos rural e urbano, masculino e feminino, disponibilidade de dados, entre outros. No que se refere aos fatores operacionais, poderíamos citar a disponibilidade política e econômica para o controle, e finalmente, quanto aos fatores sociais, o desenvolvimento humano, liberdade de regime político etc. Maiores detalhes podem ser obtidos em 1992[90].

\section{Tendências}

$\mathrm{Na}$ Europa, por exemplo, a Escandinávia está vivendo uma epidemia, onde a grande maioria de casos ocorre por transmissão homossexual, enquanto na Espanha e Itália menos da metade dos casos é devido a esta via. Nos EUA, apesar do número de infecções por transmissão homo/bissexual e UDI ter-se estabilizado, a via heterossexual cresceu pouco. Outra tendência observada é na América Latina, onde a categoria de transmissão homo/bissexual diminuiu e tem-se observado um grande número de casos em heterossexuais, explicado, pelo menos em parte, pelo aumento do número de UDIs.

No sudeste Asiático, observou-se que, quando a epidemia atingiu os UDIs e as prostitutas, cresceu acentuadamente o número de casos (Bangcoc, na Tailândia e 
Yangon na China), e trouxe, como conseqüência, uma maior magnitude na participação do padrão heterossexual na epidemia da região (1994[95]). O fato de a região contar com metade da população mundial, tendo a via heterossexual como um importante padrão na transmissão, leva a crer que um grande desastre se aproxima, caso os mecanismos de controle não sejam eficientes.

Em contrapartida, na região SubSaara africana, a infecção claramente definida como heterossexual, não teve mudança quanto à principal via de transmissão, porém sai dos centros urbanos e dirige-se para as regiões rurais, onde a população é maior, o que irá implementar as características desastrosas desta epidemia.

De uma maneira geral houve mudança, refletida na razão homem/mulher, em vários países. Nos EUA, este perfil mudou pouco, mas, mesmo assim, as mulheres estão se contaminando mais que no início da epidemia. Nas Américas (sem EUA) já atingiu a casa dos 20:1 e hoje chega a 5:1 (1994[115]). Isto pode ser atribuído, pelo menos em parte, à infecção, que vem ocorrendo predominantemente através da transmissão sexual com parceiros que se infectaram pelo contato bissexual, ou utilizando drogas injetáveis (1994[115]).

\section{No Brasil}

O Brasil é o país que apresenta o maior número de casos notificados de AIDS da América Latina, com 55.894 casos, e é superado, no quadro mundial, somente pelos EUA com 401.789 casos (1995[109]). Sua incidência continua a crescer de maneira significativa, atingindo faixas etárias cada vez mais jovens.

A distribuição de casos acumulados notificados de AIDS no Brasil referente a atividades de risco, pelo ano de diagnóstico, é a seguinte (1994[20]).

- sexual

$$
51 \%
$$

- transfusional

(UDI)

$(23 \%)$

- perinatal

$2 \%$

- não definida

$19 \%$

Como já foi referido anteriormente, as notificações de AIDS, segundo o ano de diagnóstico, estão sujeitas a uma série de erros, que necessitam de correção. Segundo o MS, estas notificações caminham da seguinte forma: 45 \% no ano do 
diagnóstico, $30 \%$ no ano seguinte e os restantes $25 \%$ nos anos subsequentes (1994[20]).

O Estado de São Paulo participa com aproximadamente $60 \%$ dos casos notificados no Brasil (1994[20]) e a distribuição, segundo as atividades de risco, basicamente acompanha o panorama nacional (1994[23]).

- sexual $51 \%$

- transfusional $35 \%$ (UDI) $(32 \%)$

- perinatal $2 \%$

- não definida $11 \%$

O problema da transmissão do HIV, através do uso de drogas injetáveis, assume papel de grande importância. Para ilustrar tal afirmativa, podemos citar a cidade de Itajaí, Santa Catarina, que, como outras, era poupada pela infecção do virus e, devido a esta forma de transmissão, aparece hoje com a segundo maior coeficiente de incidência acumulada por habitante do país (1980-94), 306,6/100.000 hab. (313 casos) perdendo somente para Santos com 364,0/100.000 hab. (1686 casos) que contribuem com $0.5 \%$ e $2,9 \%$ dos casos do Brasil respectivamente (1994[20]).

Por ocasião do estudo, o coeficiente de incidência de casos na cidade de Santos era de 62,7/100.000 habitantes; hoje este coeficiente está ao redor de $67,7 / 100.000$ habitantes (1994[20]), contribuindo com 3\% dos casos notificados do Brasil e $5 \%$ do Estado, sendo a segunda cidade do Estado e ficando atrás de S.Paulo com $53 \%$ dos casos.

Segundo a Secretaria Municipal da Saúde de Santos, a cidade contava em 1991, com 1502 casos de AIDS em pacientes adultos e sua distribuição na cidade evidencia a Orla e o Centro como os principais locais de ocorrência da doença (1991[17]).

\section{Infecção em grupos com comportamento de risco}

No início dos estudos da AIDS, através de técnicas epidemiológicas, identificaram-se os grupos de risco, associados à infecção. Posteriormente, com a identificação do vírus, um melhor conhecimento da doença e até uma mudança do 
comportamento social, principalmente nos países desenvolvidos, o risco para a infecção saiu destes grupos e passou para os indivíduos com comportamentos de risco. Atualmente, em alguns lugares, este termo também passou a ser inadequado, pois, à medida em que a infecção se dissemina na população, todos os indivíduos pertencentes a ela passam a ter chances reais de adquiri-la, exigindo deles medidas de prevenção das atividades ligadas à transmissão.

Nos países do chamado padrão I ou I/II, as prostitutas se encontram frequentemente infectadas. O uso de drogas injetáveis, a presença de doenças sexualmente transmíssiveis e o relacionamento sexual com viciados em drogas injetáveis estão intimamentes associados à infecção pelo HIV.

Na cidade de Santos foi encontrado alta frequência de infecção pelo HIV em grupos selecionados de indivíduos, incluindo mulheres grávidas. Nestes trabalhos, porém, foram utilizados critérios não uniformemente aceitos para confirmação do ensaio de rastreamento e, por vezes, não ficou claro o risco a que alguns dos grupos estavam expostos.

Em trabalho elaborado por 1991[59], observou-se que a freqüência da infecção pelo HIV 1 no grupo de prostitutas e seus parceiros sexuais desta cidade girou ao redor de 4,7 \% no período de observação (1987-1990), mantendo-se relativamente constante. Observou-se tambem que a soropositividade ao HIV 1 entre as prostitutas está principalmente associada ao uso de drogas endovenosas, não tendo sido observada infecção pelo HIV 2.

O padrão epidemiológico encontrado foi do tipo I.

O estudo de soroprevalência em usuários de drogas endovenosas, desenvolvido pela Secretaria de Saúde de Santos, vem obtendo cifras em torno de $60 \%$ de HIV positivos.

\section{A epidemia de AIDS nas comunidades de UDIs}

Esta epidemia é bastante diferente das outras por se apresentar entre os jovens em idade produtiva e estar ligada estritamente às relações humanas e comportamento de grupos. 
Em poucos países do mundo a epidemia de AIDS não está relacionada com UDIs, como em alguns países da América Central, do Sul e do Oeste da África (1994[40]).

A grande gravidade que existe nestas comunidades em relação à epidemia de AIDS é que, uma vez introduzido, a velocidade de propagação do vírus é grande (1993[126], 1994[40]), pois encontra um ambiente bastante favorável, onde os comportamentos inadequados já estão presentes, agindo como facilitador desta disseminação. Cabe lembrar que qualquer doença de transmissão parenteral terá comportamento semelhante.

Apesar da seriedade do problema, o número de UDIs ainda continua a crescer. Acredita-se que isto ocorra devido ao alto custo da droga, pois tanto a heroína quanto a cocaína quando usados pela via injetável, necessitam de uma quantidade menor para produzir os efeitos desejados, cerca de $1 / 3$ da dose se esta fosse inalada. Além disto, a via injetável produz um efeito mais intenso quando comparada às outras formas de administração (1994[40]).

Supor que os UDIs não se importam com sua saúde é falso, pois a grande maioria deles alterou seu comportamento, para se proteger, evitando o uso de seringas contaminadas. Em locais que implementaram programas de trocas e fornecimento de seringas, como estratégia de controle, houve redução no risco de infecção pelo HIV, através deste comportamento. São os casos de Glasgow (Escócia), Sidney (Austrália) que apresentaram uma redução de 84\%. Em Lund (Suécia) a redução foi de $82 \%$ e, em Nova Iorque, de $80 \%$. Nestes lugares, a prática do compartilhamento reduziu-se aos grupos mais restritos de amigos (1994[40]).

Em áreas onde a prevalência ainda é baixa, qualquer medida mais simples de controle poderá ter efeitos muito animadores, porém, onde ela já se encontra alta, será necessário um grande esforço para se atingir um objetivo modesto, caso de Bangcoc na Tailândia e Manipur na Índia (1994[40]). 


\section{Estratégias de controle}

\section{Diagnóstico}

Apesar dos grandes avanços acerca da etiologia da doença, história natural, diagnóstico da infecção e de suas manifestações clínicas, pouco se avançou no que se refere à terapêutica específica contra o HIV.

Nas manifestações secundárias da doença, a obtenção de diagnósticos precoces aumentou bastante a sobrevida destes pacientes, além de melhorar a qualidade de vida.

\section{Tratamento}

Observa-se que algumas drogas, como o Zidovudine (AZT) oferecem boas respostas a certos tipos de infecção pelo vírus, principalmente na prevenção da transmissão vertical, reduzindo a incidência da infecção neonatal em mães HIV positivas. No que se refere ao tratamento com objetivo curativo ou mesmo de prolongamento do período de incubação, os resultados obtidos e as opiniões variam bastante (1992[90]).

\section{Vacinas}

O desenvolvimento de vacinas, de uma maneira geral, passa por tres fases distintas:

- Fase I - desenvolvimento laboratorial;

- Fase II - experimentação em cobaias;

- Fase III - experimentação no homem.

Com relação à vacina contra a AIDS, a grande dificuldade está no fato de o vírus apresentar uma grande variedade morfológica. Existem, porém, algumas estruturas que são conservadas, o que permitiria ser desenvolvido no hospedeiro, um mecanismo de defesa, tranformando-as em um ponto vulnerável para o vírus. Apesar disto, as expectativas acerca do desenvolvimento de uma vacina eficaz ainda é bastante remota (1992[90]).

As vacinas têm sido desenvolvidas por várias entidades, não só com finalidade profilática, mas também terapêutica e perinatal. O objetivo da vacina profilática seria de produzir no organismo condições de reconhecimento e defesa 
contra o HIV, quando este entrar em contato com ele pela primeira vez. No caso da vacina terapêutica o objetivo é o de estimular o mecanismo de defesa do sistema imune do organismo já infectado. E, finalmente, a vacina perinatal objetiva bloquear a transmissão do virus da mãe infectada para o feto (1992[90])).

Várias destas vacinas já atingiram o estágio II de desenvolvimento, porém a dificuldade na escolha de qual delas seria indicada para passar para o estágio seguinte, é muito grande.

A OMS apresentou estratégias no desenvolvimento destas vacina mundialmente, visando criar um protocolo para os diferentes países. O vírus e os hospedeiros apresentam características próprias, sendo necessário que os vários comportamentos das vacinas sejam observados em diferentes locais. O Brasil ${ }^{3}$ é um dos países escolhidos onde este protocolo deverá ser aplicado, por ser um país em desenvolvimento, ter condições de laboratório para desenvolver e aperfeiçoar as vacinas, e onde poderão ser feitos estudos de coôrtes nas avaliações (1992[90], 1992[19]).

Como medida preventiva, a vacinação não é um recurso que pareça estar próximo e as projeções mais otimistas apontam prazos ainda longos até se obter algum resultado promissor. Resta, então, como única estratégia real de controle, as medidas preventivas que se apoiam no esclarecimento acerca da doença e seu modo de transmissão e o mais importante, num trabalho de mudança de comportamento, dirigido às mais diversas categorias de transmissão (sexual ou parenteral).

Muitas são as estratégias adotadas, dependendo do grupo alvo a que elas se dirigem. No caso específico dos usuários de drogas, que é o tema central deste trabalho, muitas experiências piloto, apesar de também contestadas, como a troca e ou distribuição de agulhas aos UDIs, vêm ocorrendo pelo mundo, algumas das quais com resultados bastante promissores (1993[39], 1993[142],1993[98]).

${ }^{3}$ Outros países escolhidos foram Rwanda, Tailândia e Uganda. 


\section{Infecções com padrão similar de transmissão}

$\mathrm{F}$

oram analisadas neste trabalho algumas das principais infecções que apresentam um padrão semelhante de transmissão do HIV e, conseqüentemente, com uma participação importânte no aspecto epidemiológico, tanto diagnóstico quanto preventivo. Foram utilizadas as infecções das hepatite virais $\mathrm{B}$ e $\mathrm{C}$ e sífilis como marcadores dos componentes parenteral e sexual respectivamente, que serão vistos com mais detalhes no decorrer do capítulo.

\section{Retroviroses do homem}

Além da infecção causada pelo HIV (1 e 2), existem na espécie humana, infecções causadas pelos "Human T Cell Lymphotropic Virus", (HTLV), os quais, nortearam as pesquisas da AIDS.

Há mais de 10 anos, desde que foi isolado o primeiro retrovírus humano (1980[117]), eles vêm sendo estudados no seus aspectos molecular, biológico, imunológico, clínico e epidemiológico relacionados com a espécie humana. Da família do HTLV, os membros mais conhecidos são os tipos 1 e 2 (1994[64]):

- O HTLV 1 é associado com leucemia/linfoma de células $\mathrm{T}$ em adultos (LLTA), com a paraparesia espástica tropical (TSP) e algumas dermatites infecciosas em crianças, embora a maioria dos infectados apresentem-se assintomáticos. Porém, apesar de assintomáticos, estes indivíduos apresentam, em sua maioria, anormalidades hematológicas e/ou imunológicas. A infecção é endêmica no Japão e Caribe, e sua transmissão é associada principalmente com à exposição parenteral, embora as vias sexual e vertical estejam também envolvidas (1994[64]). 
- O HTLV 2 é associado às doenças na espécie humana, como um ponto ainda não esclarecido completamente, apesar de haver muitos indícios de que se relaciona a distúrbios neurológicos e linfoproliferativos. Outra associação encontrada foi com os UDIs na Europa e Estados Unidos, sendo que neste foi observada, em bancos de sangue, uma maior prevalência que a encontrada para o HTLV 1 (1994[139]). Supõe-se que a via de transmissão seja parenteral, apesar da via sexual ainda permanecer incerta.

- Não se pode afirmar se há diferença entre a gravidade da manifestação clínica do HTLV 1 e do HTLV 2. Sabe-se que, além das diferenças acima expostas, o tipo I infecta predominantemente o CD4, enquanto o tipo II, o CD8. A co-infecção com o HIV parece alterar o comportamento clínico dos pacientes, porém nada está ainda esclarecido (1994[139]).

\section{Hepatites}

\section{Hepatite B}

A hepatite $\mathrm{B}$ esteve sempre relacionada à transmissão parenteral, tendo recebido várias denominações como hepatite por soro homólogo, hepatite póstransfusional, hepatite de incubação longa, hepatite associada ao "Antígeno Austrália" (AgAu), todas elas atualmente abandonadas.

$\mathrm{O}$ quadro clínico é bastante parecido com o da hepatite $\mathrm{A}^{4}$, com algumas diferenças importantes. A chance de cronificar é muito grande, podendo evoluir para cirrose, desenvolvendo, como conseqüência insuficiência hepática e, por vezes, tumores hepáticos. Esta evolução atribui-lhe uma característica mais severa. Sua forma de tranmissão é feita principalmente por via parenteral, sexual e transplacentária.

O diagnóstico etiológico pode ser feito pelo encontro de marcadores virais no soro ou no tecido hepático.

\footnotetext{
${ }^{4}$ A Hepatite A é uma forma importante de hepatite viral, que tem na via fecal-oral sua principal forma de transmissão. Apesar de existir a possibilidade de transmissão via parenteral, esta não se constitui numa via de importância epidemiológica.
} 
O período de incubação está ao redor de 45 a 160 dias, com transmissibilidade que vai de semanas antes do aparecimento dos primeiros sintomas até anos após a fase aguda. O HBsAg e ou anti-HBc são demonstráveis nos portadores.

Os marcadores atualmente conhecidos são (tabela 1): antígeno do "core" viral (AgHBc); seu respectivo anticorpo da classe IgM (anti-AgHBc IgM) ou total (anti-AgHBc total), o antígeno de superfície (AgHBs); e seu respectivo anticorpo (anti-HBs); antígeno "e" do "core" viral (AgHBe) e seu respectivo anticorpo (anti-HBe).

Tabela 1. Marcadores virais da hepatite B, segundo local de encontro e o que representa no processo de infecção.

\begin{tabular}{lll}
\hline marcador & local de encontro & função \\
\hline - AgHBc total & tecido hepático & doença ativa \\
- anti-HBc & soro & contato com VHB \\
- anti HBc IgM & soro & forma aguda ou \\
& & reagudização \\
- AgHBs & soro e tecido hepático & doença ativa \\
- anti-HBs & soro & imunidade \\
- AgHBe & soro & infectividade \\
- anti-HBe & soro & diminuição da \\
& & transmissibilidade \\
\hline
\end{tabular}

O AgHBs surge no soro de 24 a 40 dias após a exposição ao vírus B e permanece até 1 a 12 semanas após o aumento das transaminases. A sua distribuição é universal, porém existe uma maior prevalência em regiões da Ásia, chegando a 10-15\%, enquanto que nos EUA, a prevalência fica em torno de 0.3 a $0.9 \%\left(1992^{[52]}\right)$.

Pode-se obter imunidade duradoura através da produção de anticorpos antiHBs como resposta à infecção naturalmente adquirida e por imunização com vacina sintética ou vírus inativado.

Profilaticamente, pode-se administrar gamaglobulina hiperimune, fração do plasma tratada pelo calor, isentas do risco de transmissão. 
A hepatite B apresenta um mecanismo de transmissão pela via parenteral bem como sexual bastante semelhantes ao do HIV.

\section{Hepatite C}

A hepatite $\mathrm{C}$ assemelha-se bastante à hepatite $\mathrm{B}$, no que se refere à via de transmissão, quadro clínico e gravidade em relação à cronicidade. É freqüente sua associação com tumores hepaticos.

Sua forma de transmisssão parece ser exclusivamente parenteral, embora alguns autores tenham descrito, apesar de rara, também a forma sexual, como uma via de transmissão possível (1992[52]).

Seu período de incubação vai de 7 a 8 semanas, porém existem casos de até duas semanas. A transmissão vertical também pode ocorrer.

Dos indivíduos portadores de hepatite C, $60 \%$ cronificam e $10 \%$ desenvolvem cirrose hepática.

No início, foi detectado uma prevalência ao redor de 0.2 a $1.2 \%$ na população geral dos EUA e Japão ( 1989[34], 1989[79], 1989[121]). A detecção do anti-HCV indica que o indivíduo foi infectado pelo vírus da hepatite $\mathrm{C}$.

\section{Sífilis}

É uma doença sexualmente transmissível, que já foi um grande problema de saúde pública antes do advento dos antibióticos e hoje volta a ser uma moléstia preocupante, dentro deste grupo. O agente causal é o Treponema pallidum.

O diagnóstico é feito através do aspecto clínico das lesões (cancro duro, por exemplo), através da pesquisa direta do treponema em campo escuro e na pesquisa sorológica de anticorpos, dirigidos contra o agente. Atualmente o quadro clínico da sífilis tem uma classificação padronizada, o que facilita a terapêutica (1988[119]).

Sífilis recente é aquela com menos de um ano de duração. Compreende o cancro duro, secundarismo e sífilis latente recente.

Sífilis tardia é aquela com mais de um ano de duração. Compreende as lesões terciárias, como: sífilis cardiovascular, sífilis nervosa e em outras localizações. 
Sífilis congênita é a que compreende a presença de lesões dermatológicas e/ou sistêmicas, com reações sorológicas para sífilis (RSS) positivas. O recémnascido $(\mathrm{RN})$ pode ter a sorologia positiva, na ausência de doença, uma vez que os anticorpos maternos podem cruzar a barreira placentária.

A transmissão ocorre basicamente através do contato sexual e por via transplacentária. Acredita-se que a via parenteral apesar de teóricamente possível, seja bastante rara, uma vez que o indivíduo precisa receber o sangue contaminado com o treponema. A fase de parasitemia não é muito duradoura na doença ( 1988[119]).

\section{Aspectos sorológicos}

\section{Diagnóstico sorológico da infecção pelo $\mathrm{VHB}$}

$$
\text { AgHBs }
$$

O antígeno está presente quando há infecção aguda ou crônica.

O ElisA é um dos métodos utilizados para detectar o AgHBs no soro ou plasma;

\section{Anti-HBc}

$\mathrm{O}$ anticorpo anti-HBc é um marcador de contágio com o vírus da hepatite $\mathrm{B}$ (VHB) em algum momento da vida, ficando como cicatriz sorológica em indivíduos doentes ou em indivíduos que desenvolveram imunidade natural, ou seja, que negativaram o AgHBs e desenvolveram o anticorpo dirigido contra o antígeno de superfície do VHB (anti HBs) (1995[89]).

O ELISA é um dos métodos utilizados para detecção do anti-HBc no soro.

\section{Diagnóstico sorológico da infecção pelo VHC}

\section{Anti-VHC}

A detecção do anti-VHC indica que o indivíduo foi infectado pelo vírus da Hepatite C, é portador da infecção (1995[89]).

O ELISA, é um dos métodos utilizados para pesquisa do anti-VHC no soro. 


\section{Diagnóstico sorológico de sífilis}

\section{FTA-abs}

A técnica do $\boldsymbol{F T A - a b s}$ (Fluorescent $\boldsymbol{T}$ reponemal $\boldsymbol{A}$ ntigen- $\boldsymbol{A} \boldsymbol{b s}$ sorption test), usa como princípio a imunofluorescência indireta: o anticorpo específico presente no soro do paciente infectado com o Treponema pallidum adere-se ao antígeno fixado na lâmina. O complexo antígeno-anticorpo formado evidencia-se pela reação com a ajuda dos anticorpos antiglobulinas humanas marcados previamente com fluoresceína (conjugado fluorescente) que é visivel ao microscópio de fluorescência. Os soros humanos, às vezes, contém anticorpos contra agentes do grupo dos treponemas não patógenos ao homem, o que pode resultar em reação cruzada (falso positivo). Para eliminar tais reações inespecíficas, é utilizada a preparação (sorbent) com o Treponema de Reiter, não patógeno que serve para absorver os anticorpos não específicos contra o Treponema pallidum. Esta absorção nos dá uma alta especificidade para o método (1995[89]).

O FTA-abs é a primeira reação sorológica a tornar-se positiva num indivíduo infectado pelo Treponema pallidum, e última a tornar-se negativa após tratamento da infecção, porém a regra é ela permanecer positiva mesmo nos indíviduos curados, não sendo um teste utilizado para critério de cura (1995[89]).

Este teste detecta facilmente o IgM, o que é de grande utilidade na avaliação de recém-nascidos (RNs) com sífilis congênita. Neste caso o IgG passa a barreira placentária e é eliminado com o tempo, sem necessidade de tratamento, enquanto que a IgM não a atravessa. Um resultado positivo indicaria que o anticorpo foi produzido pelo $\mathrm{RN}$, isto é, ele entrou em contato com o Treponema pallidum, pois esse agente pode atravessar a barreira placentária em certo momento da gravidez. Este dado indica que o RN é portador da infecção (1995[89]). 


\section{As drogas}

D roga é qualquer substância que tem a propriedade de atuar sobre um ou mais sistemas do organismo, produzindo alterações em seu funcionamento (1993[9]). Quando as drogas provocam alterações em nível cerebral, causando modificação do psiquismo, são chamadas de psicotrópicas e a elas estaremos nos referindo, a partir de agora.

Para compreender um pouco melhor os problemas causados por estas drogas faremos uma abordagem do panorama que as circundam, nos mais diversos aspectos: biológicos, sociais e econômicos. Dentro deste capítulo, iremos nos ater, basicamente, às principais drogas psicotrópicas, sua orígem e sua ligação com o uso médico e o narcotráfico.

\section{Histórico}

É difícil, se não impossível, precisar desde quando as drogas participam da vida e da cultura dos homens, pois, desde remotas épocas, as substâncias que aliviam o sofrimento e causam mudança no comportamento são utilizadas nas mais diferentes culturas. O papel ambíguo destas drogas (de um lado o de serem indispensáveis para alívio da dor e do sofrimento e, do outro, o de serem usadas de maneira abusiva, causando vícios e danos), sempre foi um grande problema a ser equacionado.

As sociedades tentam criar regras para restringir seu uso indiscriminado, direcionando-as para as práticas curativas e religiosas; o que frequentemente acontece é que a manipulação das drogas sejam delegadas aos médicos, curandeiros e sacerdotes.

A existência de problemas em todo o mundo, relacionados ao abuso no uso de drogas, é conhecida desde remotas épocas e, é de se esperar que tais problemas 
se acentuem, dado o aumento do número de substâncias disponíveis no mercado, provocado pela pesquisa de sua aplicação em terapêutica e em paralelo, o interesse do narcotráfico em aumentar o consumo mundial, propiciando um aumento do número de consumidores.

O uso abusivo destas drogas vem aumentando significantemente desde a metade do século XIX, por várias razões: disponibilidade das drogas, expansão das comunicações e transportes, fatores sócio-econômicos, migração, rápida urbanização e mudanças nas atitudes e de valores na sociedade. A este contexto favorável, soma-se a expansão do crime organizado visando ampliar seus lucros.

Há muito tempo existe a necessidade de um controle internacional do mercado que envolve o comércio destes produtos. Se por um lado as drogas oferecem um risco ao futuro das nações, por destruir sua população infantojuvenil, por outro elas trazem um profundo conforto no que se refere à sua aplicação no campo medicinal. Para tanto, o controle internacional deve ter em mente um equílibrio de seu uso: ilícito e medicinal.

No que se refere à demanda e oferta, é preciso levar-se em conta o quanto estas drogas são indispensáveis para uso médico, devendo estar em disponibilidade suficiente para este fim. A estreita barreira existente entre a necessidade real e o abuso na utilização de certas drogas leva, por vezes, a um exagero na sua indicação, tanto do ponto de vista leigo quanto profissional.

\section{Principais drogas psicotrópicas}

As drogas psicotrópicas são classificadas de acordo com o tipo de ação que exercem sobre o Sistema Nervoso Central (1989[96]) em:

- Psicoléticos ou depressores: aqui são incluídas o álcool, os barbitúricos, opióides, solventes ou inalantes;

- Psicoanaléticos ou estimulantes: são as anfetaminas, cocaína;

- Psicodisléticos ou Perturbadores: maconha, alucinógenos, anticolinérgicos

Neste capítulo, iremos nos referir basicamente às principais drogas que estão estreitamente ligadas ao narcotráfico, tendo o objetivo de fornecer subsídios 
para compreensão de sua participação no contexto geral ligado à epidemia da AIDS.

\section{Ópio}

Derivado do látex obtido por incisão nos bulbos da papoula branca, Papaver somniferum. Seu uso ilícito é feito através do seu aquecimento para depois ser fumado, e seus principais derivados são:

- Morfina é o principal alcalóide derivado do ópio, de uso médico como um potente analgésico;

- Heroína ${ }^{5}$, derivado da morfina, de uso endovenoso, podendo ainda ser consumido por via oral, inalado e fumado.

- Codeína, derivada da morfina, dá origem aos xaropes com efeito antitussígeno e analgésicos.

Obs: Cabe lembrar que algumas drogas sintéticas, com propriedades semelhantes a estas derivadas da morfina e, por vezes mais potentes em sua ação analgésica, vão sendo desenvolvidas e com isso aumentando as opções tanto para uso legal (terapêutico) como ilegal. Assim temos como exemplo a Meperidina (Dolantina ${ }^{\mathrm{O}}$, Demerol $\left.\mathrm{O}\right)$, Fentanil (Fentanil ${ }^{\mathrm{O}}$, InovalÒ), Alfentanil e o Sulfentanil.

\section{Anfetamina}

Substância sintética de uso médico no combate ao sono e à fome.

\section{Cocaína}

Derivado da folha da coca, Erythroxylum coca, na forma de um pó branco obtido após tratamento, em laboratório, com éter, acetona e ácido sulfúrico. Seu uso pode ser por via endovenosa, inalado e via oral e, seu principal derivado é o crack, derivado químico da pasta da cocaína, mais barato e mais tóxico, podendo ser fumado e inalado.

\footnotetext{
${ }^{5}$ Através de processos de refinamento, 10 gramas de heroína comum, transformam-se em 1 grama de "china white" ou heroína número 4. Esta é a mais pura das heroínas, chegando a um nível de pureza ao redor de 98\%. Em Nova Iorque, ela é chamada chamada de "Ferrari das drogas" $(1993[130])$.
} 


\section{Maconha ou "Marijuana"}

Derivada da planta Cannabis sativa, que é encontrada praticamente em todo o mundo, é de fácil cultivo, não necessitando de grandes cuidados ou técnicas para o seu plantio, sendo conhecida dos chineses desde $2700 \mathrm{aC}$. É uma das drogas psicotrópicas mais utilizadas no mundo, sendo obtida através da maceração das folhas e flores secas. Tem como principal derivado o haxixe ou kif, obtida através da resina tirada das extremidades florais da planta, sendo comumente fumada, misturada ao tabaco.

\section{$L S D$}

O ácido lisérgico, é o mais poderoso dos alucinógenos, sendo obtido através da hidrólise de alguns alcalóides vegetais, principalmente o centeio. A via mais comum de uso é através da absorção por via oral (sublingual), onde uma gota do ácido é adicionada sobre pequenos pedaços de açucar, papel, etc.

\section{Tentativas de controle}

$\mathrm{Na}$ tentativa de controle desta "epidemia", a comunidade internacional, cada vez mais, vem se organizando para obter mecanismos de avaliação e controle, que vão desde o uso abusivo destas substâncias até seu comércio ilícito (o narcotráfico). Qualquer medida de controle adotada deve assumir um caráter universal, pois, se aplicada individualmente, terá suas chances de sucesso reduzidas $(1993[9])$.

Historicamente, uma das primeiras iniciativas de controle internacional de drogas psicotrópicas foi a Conferência de Shangai (1909), onde foram dados os primeiros passos rumo ao combate ao problema. A partir de então se sucederam (1993[9]):

- 1a Convenção Internacional em Haia, mais conhecida como a Convenção do Ópio (1912), que regulamentou a produção e comercialização da morfina, heroína e cocaína;

- Convenção Única (Nova Iorque, 1961), onde foi elaborado um compêndio completo sobre drogas, visando um maior controle sobre as drogas narcóticas, gerado pelo grande aumento do uso deste tipo de droga, na década de 1960; 
- Convenção sobre substâncias psicotrópicas (Viena, 1971), apoiado na Convenção Única de 1961;

Em 1972, foi proposto uma diminuição da demanda e do consumo ilícito, com uma proposta, também de limitação para uso médico, da produção, manufatura, exportação, importação, distribuição, comercialização, uso e posse dessas drogas. Foi convocado um número maior de países para se submeterem à estimativa do INCB (International Narcotics Control Board), que possibilitou um melhor conhecimento acerca da quantidade de drogas utilizadas com propósito médico, sua produção e estocagem para consumo anual.

Apesar de todo este esforço o que se observa é que o consumo de drogas vem aumentando e é tido como alarmante.

O INCB, em seu relatório de 1985, mostra que o abuso de uma variedade de drogas - maconha, cocaína, opiáceos, substâncias psicotrópicas de uma maneira geral e outras drogas produtoras de dependências - permanece em alto nível, na maior parte do mundo. Em alguns países está até mesmo se elevando e poucos não são afetados. Os problemas de saúde aumentam com o uso concomitante de drogas, principalmente associado ao álcool e pelo aparecimento de drogas mais potentes e meios de administração mais perigosos. O abuso pelos jovens, principais consumidores, interfere acentuadamente no futuro dos países.

É interessante observar que, no Brasil, existe uma grande dificuldade burocrática e um grande preconceito em relação ao uso de opiáceos (morfina ou derivados) como analgésicos, fazendo com que autoridades internacionais se pronunciem desfavoravelmente a este respeito. Segundo o CEBRID (Centro Brasileiro de Informações sobre Drogas psicotrópicas), no Brasil utiliza-se uma quantidade dessa medicação muito menor que no exterior; são feitas 31.000 doses/dia, sendo a previsão de uso seria de 500.000 a 1 milhão de doses/dia. Isto seria gerado pelo preconceito e comodidade da categoria médica e pela grande dificuldade legal para liberar tais medicamentos. Esses dados sugerem a necessidade de se trabalhar melhor a discussão técnica acerca da utilização destas drogas e numa reavaliação destes impecílios legais ora vigentes na legislação do país $(1993[14])$.

Por outro lado, há um aumento crescente no comércio ilegal de drogas psicotrópicas, observado por medidas indiretas do número de apreensões e da quantidade da droga apreendida. Além disso, o narcotráfico vem melhorando sua 
organização, apresentando, cada vez mais, melhores recursos para atingir seus objetivos, desde sofisticadas tecnologias e armamentos até meios de transporte com grande autonomia de viagem. Quando, por exemplo, dentro de uma determinada rota, ocorrem apreensões e grande ação por parte dos policiais para seu desmantelamento, esta desaparece e, quase que automaticamente, surgem novas, de acordo com estas ações (1993[130]).

\section{O narcotráfico}

A expansão do comércio de drogas no mundo vem crescendo nos últimos anos, principalmente após os anos 60 , quando uma modificação do comportamento social na Europa e EUA trouxe grande impulso para o aumento do seu consumo.

Apesar de todo esforço da sociedade para tentar deter o avanço deste comércio, as chances de sucesso são mínimas, devido à complexidade do problema e a grande soma de dinheiro envolvida.

O narcotráfico comercializa pelo mundo principalmente drogas de origem vegetal, onde participa desde sua produção, transformação, transporte, até sua distribuição. Dentre as principais culturas de vegetais psicotrópicos temos a da maconha, da coca e a da papoula.

A maconha, Cannabis sativa, é cultivada praticamente em todo o mundo, porém existe um importante comércio com a Europa, através da África (Marrocos, Argélia, Congo, Zaire, Nigéria) e Ásia (Turquia, com rotas pelo Mediterrâneo)

A papoula, Papaver somniferum, tem sua origem no oriente e sua cultura é feita principalmente no Triângulo de Ouro, que é formado pela Tailândia, Myanma (antiga Birmania) e Laos, no Cinturão de Ouro, que é formado pelo Afeganistão e Paquistão e, finalmente, na América, pela Colômbia

A cocaína, Erythroxylum coca, originária da América, tem sua produção apoiada, principalmente, nos altos vales andinos (Colômbia, Peru e Bolívia).

\section{Números do tráfico}

Segundo fontes da Polícia Federal, estima-se que a produção mundial de heroína atingiu cerca de 6500 toneladas no ano de 1993 e; só o Triângulo de 
Ouro participou com 2700 toneladas. Estima-se que a heroína no ano de 1993, gerou um lucro ao redor de 40 bilhões de dólares (1993[130]).

O preço da droga de maneira geral varia de lugar para lugar. Em Amsterdam a heroína custa cerca de 60 mil dolares o kg, enquanto que em Nova Iorque a mesma quantidade da droga chega a custar até 90 mil dólares.

O comércio da cocaína é estimado em aproximadamente 1,6 a 2 mil toneladas por ano sendo que 3/4 deste valor é destinado aos EUA. Isso significa um faturamento anual de 500 bilhões de dólares. Em Nova Iorque o preço da cocaína chega a custar 30 mil dólares $/ \mathrm{kg}$.

Segundo dados da Polícia Federal, o Brasil possui 350.000 usuários de drogas e, só em São Paulo, cerca de 100.000 foram detidos por uso da droga nos ultimos 20 anos. Acredita-se que, no Rio de Janeiro, mais de 150.000 pessoas trabalham para traficantes (1993[130]).

\section{As organizações criminosas}

A Hong Kong Connection, importante organização criminosa chinesa, abrange desde camponeses, líderes locais, militares até as tríades chinesas ${ }^{6}$, e as "tongs", que são grupos de amigos dos chineses no exterior, organizações responsáveis pela distribuição, a partir dos "chinatowns".

Os cartéis da Colômbia e Bolívia (Cali e Medellín) formam as mais importantes organizações no comércio da cocaína no mundo, estando associados à Máfia italiana, na sua distribuição pela Europa e Estados Unidos.

Antigamente a droga era enviada aos países consumidores na sua forma bruta, o que implicava em maior volume transportado e na necessidade de se criarem laboratórios para refinamento nestes países de destino. Com a ação policial mais intensa na repressão do comércio ilegal de drogas, o narcotráfico teve que se adaptar, criando laboratórios nos próprios países produtores. Isto facilitou o

\footnotetext{
${ }^{6}$ Tríades chinesas: tiveram origem política na China no início da era cristã e a partir de 1900 foram transformadas em organizações criminosas. Hoje existem 5 principais tríades (Sun Yee On - Futuro de Justiça e Paz; 14K; Wo Sing Wo - Grupo Harmonia; Sociedade do Bambu; Tai Hung Chai Sociedade do Grande Circulo) com aproximadamente 120.000 membros. As tríades são ligadas à imigração clandestina chinesa. Yunnan (China) para Vancouver (Canadá), São Francisco e Los Angeles (EUA) (1993[130]).
} 
transporte da droga em estado puro, pelo menor volume, porém trouxe uma grave conseqüência para estes países, pois a mesma passou a ser acesssível nos países produtores e acabou por criar um mercado consumidor novo. Além disto, os donos da droga passaram a pagar seus intermediários com a própria droga, desenvolvendo, desta maneira, um comércio local. Desse modo, os países produtores passaram a se comportar também como consumidores e, conseqüentemente, a receber toda a herança oferecida por esse comércio.

As vantagens que o narcotráfico oferece aos povos que habitam as áreas produtoras (Sudão, Etiópia, Cordilheira dos Andes, Sahara, regiões em torno do Himalaia, Ásia Central) são muito grandes. Por serem áreas muito pobres, onde a principal atividade econômica é a agrícola, o narcotráfico paga, pelo cultivo da droga, um preço que jamais estes povos conseguiriam com qualquer outro produto. Os entorpecentes produzidos nestas áreas fornecem um lucro enorme, transformando bandos em superpotências criminosas, com alto poder de negociação com governos e até manipulação de políticos em vários países, principalmente do terceiro mundo que, desde já, ameaçam, concretamente, o sistema financeiro internacional.

\section{Estratégias de controle do tráfico}

Este é um tema bastante polêmico e de difícil abordagem, uma vez que envolve vários aspectos, desde o biológico, passando por estratégias socialmente conflitantes, chegando à própria segurança nacional de um país.

A política de repressão ao tráfico é, sem dúvida, a que vigora na totalidade dos países no mundo, diferindo de um país para outro, pela tolerância de suas legislações, variando entre as mais amenas, como Holanda, Suíça, Espanha, Colômbia, até as mais rigorosas, que prevêem prisão perpétua e até pena de morte aos envolvidos, casos da Turquia, Filipinas e Indonésia.

$\mathrm{Na}$ avaliação da política de repressão ao narcotráfico, cada vez mais atingese o consenso acerca de sua ineficácia. Quando se analisa historicamente a "lei seca", que vigorou nos Estatos Unidos da América de 1920 a 1933, proibindo a produção, comercialização e consumo do álcool, observou-se que organizações criminosas, como a Máfia, principalmente, aproveitaram-se desta política para 
tornarem-se extremamente poderosas e organizadas, em virtude das grandes somas de dinheiro que capitalizavam.

Países como os Estados Unidos, que possuem grandes recursos financeiros, defrontam-se com a incapacidade de deter o contínuo crescimento deste comércio. Cerca de 8 bilhões de dólares, somente de verba federal, sem contar Estados e Municípios, são aplicados anualmente, só na repressão e, mesmo assim, não se conseguiu evitar o aumento do consumo destas drogas.

Ora, se estes países, com grandes recursos aplicados nesta estratégia, não obtêm sucesso em seu objetivo, como esperar este sucesso de países onde tais recursos existem, por vezes, apenas de maneira simbólica?

A procura de estratégias alternativas surge hoje, fazendo parte de debates ao redor do mundo havendo para cada uma delas, fortes partidários bem como opositores.

Iremos apresentar com finalidade de citação, as estratégias mais discutidas e por vezes aplicadas, mesmo que timidamente, em alguns locais. Pela falta da precisão do que realmente significa cada uma delas, muitas vezes, verifica-se uma confusão entre a estratégia e suas ações.

\section{Descriminação "excluir a criminalidade"}

Refere-se especificamente ao uso de drogas consideradas ilícitas e sua abordagem criminal. No Brasil a regra é a aplicação de penas semelhantes, tanto para o usuário como para o traficante. Com referência a essas penas, é cada vez mais aceito, mundialmente, a necessidade de se diferenciar a punição para cada caso, isto é, se o envolvido é usuário ou traficante. O estado de Nova Iorque, por exemplo, estuda a amenização das penas aplicadas aos usuários de drogas, liberando com isso um grande contingente de pessoas, em torno de 4.000 vagas por ano, do seu sistema penintenciário.

Outro exemplo desta estratégia, é o da toxicomania com assistência médica, isto é, autorização da prescrição de entorpecentes por médicos aos toxicômanos com vícios mais pesados (como o exemplo clássico da metadona para substituir a heroína). Isto ofereceria possibilidades para um melhor acompanhamento médico aos viciados e marginais sem dinheiro, que usariam material adequado, diminuindo, assim, o risco de transmissão de doenças via parenteral. A metadona é xarope, o que vem de encontro com a prevenção de doenças de transmissão 
parenteral, principalmente AIDS e hepatites. O fornecimento gratuito diminui o roubo e a prostituição que têm, como fim, a obtenção da droga.

Argumento contrário: a metadona é um opiáceo que não leva à desintoxicação, cria dependência maior que a heroína, não produz sofrimento com sua abstinência e não é perigoso do ponto de vista social, criando-se, desta maneira, um "drogado legal", que não teria nenhuma razão para abandonar o vício. Em Liverpool, por exemplo, num projeto piloto, 3/4 dos toxicômanos usam metadona há 10 anos (1993[130]).

\section{Liberalização "autorizar, como medida geral, o livre mercado"}

Seria a estratégia que rege hoje a política aplicada ao álcool: permitir sua comercialização, distribuição e consumo, diante de algumas regras préestabelecidas. Alguns defendem essa hipótese, caso fosse limitada às "drogas leves" como a maconha; haveria uma desobstrução dos tribunais e prisões pelo seu grande uso e participação nestes crimes. Isto traria poucas repercussões negativas tanto do ponto de vista individual como social;

Argumento contrário: Antigamente julgava-se que a concentração do tetra hidro canabidiol (THC), princípio ativo da maconha, era ao redor de $4 \%$, hoje sabe-se que atinge 30\%; daí surge uma das grandes dúvidas: como separar uma "droga leve" de outra "pesada"? Se os adolecentes representam de 30-50\% da população consumidora, como reprimir seu uso, se este passa a ser legal? Até que ponto esse uso é inofensivo?

\section{Legalização "ato de legalizar, dar força de lei"}

Representa claramente o fim da proibição para as drogas. A base filosófica desta estratégia é de que "a droga narcótica não é proibida porque é perigosa, ela é perigosa porque é proibida". Diminui o risco de transmissões de doenças, reduz o preço, diminui a delinqüência, desmonta a estrutura do narcotráfico. Por ser uma estratégia radical, defendida por importantes autoridades no assunto, fica ainda muito mais difícil avaliar as suas implicações na sociedade.

$\mathrm{Na}$ prática, várias são as experiências em busca de alternativas mais eficientes, nas diversas sociedades, principalmente da Europa. Estas alternativas, sempre estarão sujeitas a argumentos contrários e favoráveis. O fim da proibição pode, por exemplo, ser considerado como estímulo ao consumo e já existem experiências na Suíça e Espanha, que delimitaram áreas onde a droga é liberada e 
que mostraram um aumento no número da população de consumidores, oriundos principalmente de regiões vizinhas. A dificuldade da avaliação de medidas alternativas como esta, é que, por ser uma atitude isolada, cria uma falsa realidade, pois traz uma demanda exagerada ao local, o que não aconteceria caso fosse aplicada globalmente.

Estamos diante de um quadro bastante desolador, em que os maiores entendidos do assunto como, por exemplo, o diretor da InterPOL (Polícia Internacional) sentem-se desanimados diante desta batalha. Poucas chances são as de sucesso, a menos que alguma luz venha a iluminar este caminho, bastante sombrio, onde tudo o que se especula é apenas um pano de fundo de dimensões desconhecidas (1993[130]).

No início deste trabalho, foi proposto discorrer sobre os temas AIDS, infecções de padrão similar de transmissão, drogas e seu comércio, onde pudemos contextualizar a dimensão, complexidade e o grande número de variáveis a serem avaliadas, no entendimento deste tema. A seguir, faremos uma abordagem sobre os modelos matemáticos e sua utilização como instrumento em epidemiologia. 


\section{Modelos matemáticos e seu uso em epidemiologia}

N o final do século XIX, com as então recentes descobertas da bacteriologia
por Louis Pasteur e Robert Koch, surgem novas teorias para explicar algumas doenças e epidemias, sendo criados conceitos revolucionários, como o da infecção, do agente causal, do organismo infectante e do suscetível. Quase que simultaneamente, começam a ser desenvolvidos os primeiros modelos matemáticos ([65], 1908[122]) para auxiliar a compreensão do comportamento de uma epidemia.

Este instrumento foi se tornando de difícil aplicabilidade, pois, para o seu desenvolvimento, era necessário aumentar a complexidade dos cálculos, tornandoo, assim, intratável, do ponto de vista matemático.

Com as novas condições de vida nos países desenvolvidos, como reflexo da melhoria da higiene, do saneamento básico, da qualidade da alimentação, entre outros, associadas à descoberta dos antibióticos e vacinas, as moléstias infectocontagiosas tiveram sua incidência reduzida sensivelmente e passaram a ocupar papel secundário nos problemas de saúde coletiva destes países. Esta mudança no perfil epidemiológico fez com que as moléstias crônico-degenerativas, principalmente o câncer e as moléstias cardiovasculares, assumissem um papel de destaque. Com a atenção da sociedade e dos técnicos voltados para estas doenças, a epidemiologia, no uso de seu único instrumento quantitativo de então, a estatística, passa a desenvolver técnicas cada vez mais apuradas no campo da causalidade. Cabe lembrar, porém, que, nos países em desenvolvimento, as moléstias infecto-contagiosas, ao contrário do que acontece nos países desenvolvidos, ainda são responsáveis por altas taxas de morbidade e mortalidade. Estes países, entretanto, são desprovidos de tradição e de recursos econômicos para 
pesquisa e por isso não conseguem produzir ou direcionar o curso de suas pesquisas para solucionar seus problemas, junto aos orgãos financiadores e aos organismos internacionais.

Uma mudança no curso da história veio a alterar o painel que se montara na saúde coletiva destas sociedades desenvolvidas, com o surgimento de novas síndromes infecciosas. Entre elas estão:

- Legionelose, ou doença dos legionários, causada por uma nova bactéria a Legionella pneumophilia, que contamina aparelhos de ar condicionado e que tem a capacidade de desenvolver, no organismo hospedeiro, uma pneumonia atípica;

- Borreliose, estado agudo febril, causado por uma espiroqueta do gênero Borrélia. É uma zoonose que atingiu alguns milionários americanos; ao ornamentarem seus jardins com animais selvagens, como o veado campestre, por exemplo. Desta maneira ficavam mais expostos à infestação por piolhos, que agiam como hospedeiros destes agentes infecciosos;

- Síndrome do Choque Tóxico, estreptococcia causada pelo uso inapropriado de absorvente íntimo contaminado;

- encefalites virais, surgidas no Japão e Oriente;

- febres hemorrágicas, causadas por vírus (RNA), com alta taxa de letalidade. Surgiram provavelmente pela grande e rápida depredação do ambiente, que proporcionaram condições para um contato maior entre o homem e animais silvestres. O dengue e a febre amarela, além das suas manifestações clínicas clássicas, surgem com formas hemorrágicas decorrentes deste favorecimento do contato do homem com múltiplas cepas virais, através do mosquito.

Outras formas novas de febre hemorrágica surgidas principalmente após a II Guerra Mundial, causadas por vírus da família Aeranavirus, propiciadas por um aumento do contato do homem com roedores atingiram Junin, na Argentina, Machupo, no Peru (pela devastação dos prados e florestas) e Lassa na África (pela degradação do ambiente na exploração de minas de diamante); e ainda vírus da família Filaviridae, 
que são os Manipur e Ebola vírus, que têm como reservatório, os macacos verdes africanos e,

- finalmente, a pandemia da AIDS.

Estes fatos acabaram por fazer com que estes países se defrontassem novamente com as moléstias infecciosas como grave problema de saúde, trazendo, como conseqüência, a necessidade de se desenvolver uma metodologia aplicável, além das até então conhecidas, que pudesse colaborar na compreensão e controle destas epidemias.

Poucos foram os países desenvolvidos que mantiveram, ao longo deste período, tradição nas pesquisas das moléstias infecto-parasitárias. Dentre eles, destacam-se a Inglaterra e alguns outros países europeus, marcados pelas suas características colonialistas, que ainda mantêm sua atenção às moléstias infectocontagiosas, comuns nas colônias e em seus cidadãos que, por força das circunstâncias, vez por outra viam-se envolvidos com elas. Devido a isto, desenvolveram-se, em locais como Londres, centros de estudos de moléstias tropicais, que até hoje são referências para o mundo, ao contrário dos EUA, que voltaram sua atenção quase que exclusivamnete para as moléstias crônicodegenerativas.

Com o desenvolvimento da microbiologia, parasitologia, e biologia molecular, as causas das moléstias infecciosas e parasitárias têm sido determinadas com relativa rapidez e facilidade, o que mostra que a causalidade das doenças infecto-contagiosas deixou de ser um problema central para a epidemiologia moderna.

A epidemiologia passou, então, a necessitar de um instrumento capaz de fornecer outros dados em que pudesse se apoiar e analisar um sistema de maneira dinâmica. Com esses dados, poderia, escolher uma estratégia de controle, diante de uma situação endêmica ou epidêmica de uma comunidade. Além disso, poderia prever o comportamento futuro da doença infecciosa na população estudada, diante da estratégia aplicada. Surgiu, assim, a idéia de se usarem os modelos matemáticos, que teriam potencialidade para fornecer tais respostas.

Com a criação e o desenvolvimento da ciência da computação, associada à evolução teórica da matemática, criaram-se condições que permitiram uma maior capacidade no tratamento de modelos. A possibilidade de se trabalhar com modelos e cálculos mais complexos trouxe, como conseqüência, um 
aprimoramento na teoria e conceitos, abrindo espaço para sua aplicabilidade prática.

O que se tem observado atualmente é que o número de publicações de modelagens vem aumentando acentuadamente e, apesar de sua utilização pelos epidemiologistas ainda ser muito tímida, observa-se uma tendência de que a epidemiologia moderna deverá incorporar ao seu arsenal, além das técnicas estatísticas, as matemáticas e as computacionais ( 1987[92] 1992[93]).

\section{Definição de modelo}

Um modelo pode ser definido como: "a representação de um objeto, sistema ou idéia, de alguma outra forma que não a da entidade representada" (1975[129]).

\section{Considerações gerais}

Não é raro encontrar, entre os profissionais das áreas das ciências biológicas, um certo desconforto, quando se deparam com a linguagem matemática. No entanto, na epidemiologia, todos os instrumentos disponíveis para compreender e modificar um fenômeno, no caso, a endemia/epidemia, não devem ser desconsiderados. A resistência que existe em torno dos modelos matemáticos, dentro da área biológica, ainda é bastante grande, pois é da compreensão que vem a aceitação. Um exemplo simples da aplicabilidade de modelos para ajudar na compreensão de sistemas biológicos é descrito por Maynard Smith, em 1968, e, posteriormente, desenvolvido por 1978[116], ao analisar o comportamento de uma população de moscas, através de um experimento, onde se manteve constante a quantidade de alimento oferecida. Desta maneira, foi obtido uma curva populacional em que havia uma oscilação em torno de valores por vezes altos, por vezes baixos, até bem próximos de zero (n2). Este tipo de comportamento não seria o padrão clássico de curva esperada para a condição de competição pelo alimento (n1). Esta oscilação só foi possível ser reproduzida, através de uma função matemática, quando foi considerada a existência do ovo, como parte do ciclo biológico da mosca, que foi chamado de "time interval" (figura 2). 
Figura 2. Crescimento populacional hipotético com e sem atraso ou "time interval"

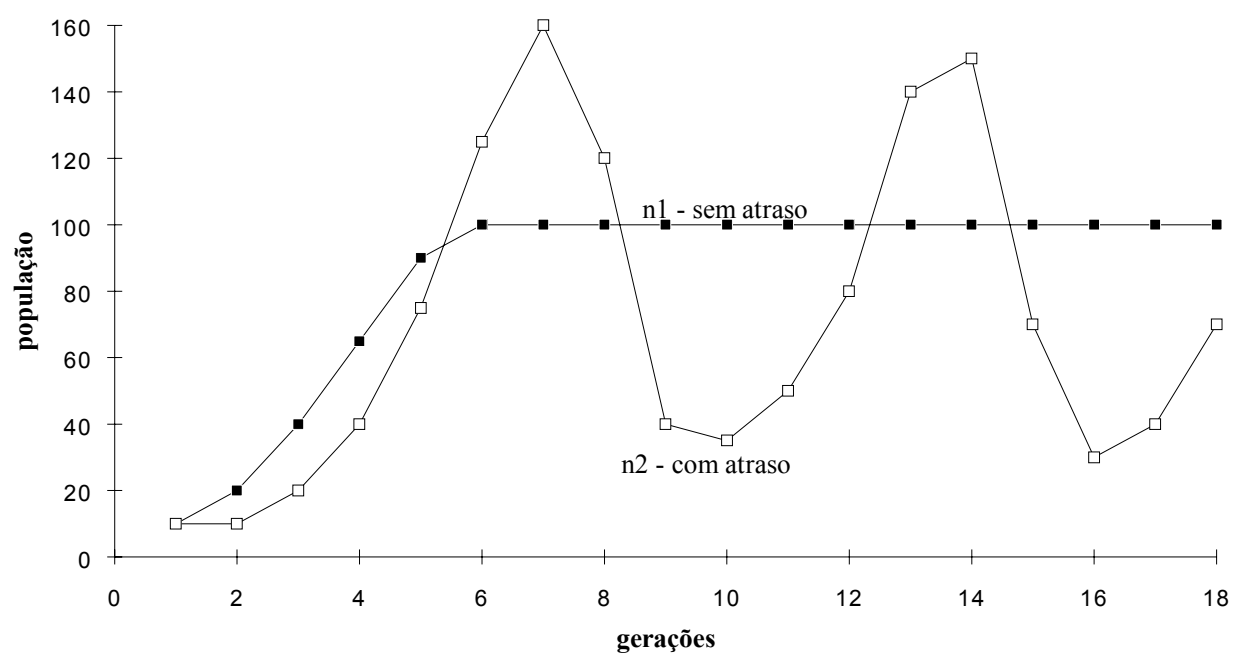

Fica claro aí que, mesmo sem se saber a priori da existência desta característica do ciclo biológico da mosca (o ovo), através de funções matemáticas, saberíamos que alguma variável deveria existir nesta população para explicar tal comportamento e que não se tratava de uma variação populacional explicada somente pela competição pelo alimento.

\section{Elaboração de um modelo matemático}

Os modelos matemáticos podem ser:

- determinísticos, quando dependem exclusivamente das condições iniciais do sistema;

- probabilísticos ou estocásticos, quando se considera a probabilidade da ocorrência de determinados fatores;

- mistos, que são uma associação de ambos.

Do ponto de vista biológico, eles partem de estruturas simples do tipo suscetível $\rightarrow$ infectado para estruturas com um maior realismo, que podemos chamar de sistemas multicompartimentais, por estar levando em conta uma quantidade maior de variáveis (ou estágios da doença). 
Os modelos aplicados às molestias infecto-parasitárias apresentarão características distintas, dependendo do que está sendo estudado. Existe uma classificação relativa à forma do agente infectante (ou parasita), que os divide em dois grandes grupos: os microparasitas, organismos que têm reprodução direta no hospedeiro, usualmente com altas taxas de reprodução, por exemplo, vírus, bactérias e protozoários e os macroparasitas, organismos que não têm reprodução direta no hospedeiro definitivo, por exemplo, helmintos ( 1979[2]). Os primeiros exigem do modelo uma estrutura compartimental, onde exista "doença" e "não doença", isto é, uma estrutura de prevalência, enquanto o outro exige uma estrutura de densidade, pois, neste caso, a morbidade depende da carga parasitária adquirida pelo indivíduo.

Os modelos desenvolvidos para doenças transmitidas por vetores têm a característica de, no seu mecanismo de transmissão, estar levando em conta a existência de duas populações distintas: a do hospedeiro e a dos vetores, além do agente.

Os modelos podem considerar a estrutura etária da comunidade, que são importantes por exemplo, em doenças comuns na infância (sarampo, rubéola), onde os parâmetros epidemiológicos são funções da idade.

Outro aspecto que pode ser evidenciado é a questão da homogeneidade e heterogeneidade do sistema. Quando nos referimos a uma interação homogênea estamos tratando de um valor médio, o que é bastante conveniente, enquanto, na interação heterogênea, os valores são discretizados por categorias (taxa de contato, atividade sexual, sexo, estrutura sócio-econômica,etc.).

Ao ser elaborado um modelo, deve-se observar que, à medida em que ele se aproxima da realidade biológica a qual representa, mais difícil a tratabilidade matemática. Daí a arte na elaboração de um modelo consistir em conseguir equilibrar muito bem estas duas vertentes, eliminando realismos que pouco influenciariam num resultado final ( 1992[93]).

\section{Objetivos}

Além das aplicações dos modelos acima mencionadas, podemos sumariar seus objetivos, dentro da epidemiologia, da seguinte forma:

- compreensão do fenômeno estudado; 
- identificação de pontos fracos do sistema para que possam ser apontados e conhecidos seus parâmetros;

- identificação de pontos críticos;

- identificação de pontos sensíveis para uma intervenção;

- predição.

Uma das grandes vantagens dos modelos é a possibilidade de serem usados para fazer simulações "sensu latu", que conseguem criar, em um computador, os mais variados ambientes. Desta maneira, através de variações dos parâmetros, é possível observar o comportamento do sistema e suas tendências através do tempo - passado ou futuro - com previsões de 1, 2, ou 100 anos, envolvendo as mais diferentes populações de hospedeiros e agentes. Também pode-se trabalhar com diferentes taxas de cobertura vacinal e assim sucessivamente, oferecendo uma gama enorme de alternativas para serem analisadas, no tempo e espaço. Enfim, podemos resumir sua aplicabilidade para:

- descrever o comportamento dos sistemas;

- construir teorias ou hipóteses que expliquem o comportamento observado;

- usar estas teorias ou hipóteses para prever o comportamento futuro do sistema.

\section{Estratégias de controle}

Consiste em achar um instrumento quantitativo com capacidade preditiva, que ajude a compreender um fenômeno mais refinadamente. Se adotarmos um tipo de medida diante de determinada doença, qual o comportamento esperado para o sistema?

Existem, basicamente, quatro tipos básicos de intervenções que podem ocorrer em um sistema para o controle de uma determinada doença:

- Imunização: ativa/passiva;

- quimioterapia (profilática/curativa);

- educação (medidas sanitárias),

- controle de vetores e/ou hospedeiros intermediários. 


\section{Novos conceitos em epidemiologia a partir dos modelos}

Analogamente à estatística, que contribuiu dentro da epidemiologia com conceitos importantes na compreensão das epidemias, como por exemplo, incidência, prevalência, amostragem, entre outros, a matemática, através dos modelos, vem também contribuindo com conceitos do tipo força de infecção, limiar, nível crítico, razão de reprodutibilidade basal, $\boldsymbol{R}_{\boldsymbol{0}}$, entre outros. Descreveremos a seguir estes conceitos.

\section{Força de infecção}

Um dos mais importantes conceitos surgidos com os modelos matemáticos é o da força de infecção $(\lambda)$ de uma doença, definida como a taxa com que um indivíduo suscetível adquire a infecção, podendo ser expresso como o número de indivíduos que adquirem esta infecção por unidade de tempo.

Pode ser estimada de forma direta ou através de dados epidemiológicos de soroprevalência ou notificação.

Uma forma de definir $\lambda$ é relacioná-la com o número de infectados, onde se admite que seja linearmente proporcional a esta variável, expresso na equação:

$$
\lambda=\beta \int_{0}^{\infty} Y(a, t) d a
$$

Onde $\beta$ é o parâmetro de transmissão, que combina uma série de fatores característicos da infecção na população em estudo. Este conceito é apresentado no próximo item deste capítulo.

Uma definição mais geral e próxima da realidade de $\lambda$, é quando o consideramos dependente da idade, representado na equação:

$$
\lambda(a, t)=\int_{0}^{\infty} \beta\left(a, a^{\prime}\right) Y\left(a^{\prime}, t\right) d a^{\prime}
$$

onde $\beta\left(\boldsymbol{a}, \boldsymbol{a}^{\prime}\right)$ é a probabilidade de um indivíduo infectado de idade $\boldsymbol{a}^{\prime}$ de infectar um suscetível de idade $\boldsymbol{a}$.

A estimativa de $\boldsymbol{l}$ fornece elementos para avaliarmos as mudanças causadas pelas intervenções do tipo imunização, quimioterapia entre outras. 
[63], [61], através de métodos estatísticos de dados de soroprevalência, estratificados por idade, determinaram o valor de $\boldsymbol{l}$ médio para o sarampo e de doenças comuns na infância, respectivamente, para determinada população.

Uma outra maneira, mais simples, de se estimar $\boldsymbol{l}$, é através do inverso da idade média, $\boldsymbol{A}$, que a população de hospedeiros adquire a infecção, numa dada comunidade (1991[6]).

Através de dados epidemiológicos de incidência, número de novos casos, ou prevalência, número de pessoas infectadas em um determinado tempo, pode-se chegar a estimativa destes parâmentros. Este método foi desenvolvido por [61]. Tais dados podem ser obtidos de forma estratificada, de acordo com a idade, sexo, e outros. A tabela 2 apresenta alguns destes valores estimados para algumas infecções.

Tabela 2. Valores estimados da idade média de aquisição da infecção, A, em anos, para várias infecções, de acordo com o local e período (1991[6]).

\begin{tabular}{|c|c|c|c|c|}
\hline infecção & & $A$ & local & período \\
\hline \multirow[t]{5}{*}{ rubéola } & & $9-10$ & EUA & $1966-8$ \\
\hline & & $6-7$ & Polônia & $1970-7$ \\
\hline & & $2-3$ & Gâmbia & 1976 \\
\hline & $*$ & $7-8$ & São Paulo & 1987 \\
\hline & $*$ & $7-8$ & Caieiras (SP) & 1990 \\
\hline \multirow[t]{3}{*}{ sarampo } & & $5-6$ & EUA & $1955-8$ \\
\hline & & $2-3$ & Marrocos & 1962 \\
\hline & & $1-2$ & Tailândia & 1967 \\
\hline
\end{tabular}

$*(1994[10])$.

O incoveniente deste processo é o fato de fornecer um valor médio constante para todas as idades. 
A força de infecção é bastante utilizada para avaliar o comportamento de uma comunidade frente a uma determinada vacina.

Através deste parâmetro, é possível obter-se:

- $\quad$ a idade ótima para se imunizar uma população, de modo a se controlar determinada doença;

- a fração de uma determinada população, que deve ser efetivamente tratada profilática ou curativamente, para controlar a epidemia;

- a melhor estratégia frente a determinada epidemia e/ou endemia;

- $\quad$ predição do custo, para escolha da estratégia mais eficiente.

\section{O Parâmetro de transmissão ( $\beta)$}

O Parâmetro de transmissão beta, $\beta$, é uma característica da infecção, numa determinada população. É uma combinação de diversos fatores, desde as características biológicas, como comportamentais e sociais dos hospedeiros, frente à infecção. Assim sendo, o parâmetro de transmissão beta pode indicar o número de contatos entre suscetíveis e infectantes, ou representar uma taxa de transmissão da doença. Medir este parâmetro diretamente é quase impossível para a maioria das infecções no homem.

Se quisermos avaliar o impacto provocado pelas intervenções, como vacinação e quimioterapia entre outras, devemos conhecer, pelo menos a forma de $\beta$. Estes programas de intervenção mudam o valor de $\lambda$, mas não de $\beta$. Para avaliarmos, por exemplo, o impacto de uma intevenção, devemos, primeiramente, determinar o valor de $\lambda$ antes da intervenção ( $\lambda$ de controle), em seguida determinar a separatriz do parâmetro $\beta$ e, então, estimar os novos valores (1993[36]).

\section{Limiar ("Threshold")}

Um dos conceitos mais importantes na epidemiologia matemática, é o chamado "princípio da ação das massas" (1945[141]), onde a taxa de propagação da infecção é considerada proporcional ao produto da densidade de suscetíveis pelo número de infectantes. Temos então, que o curso de uma epidemia depende da taxa 
de contato entre suscetíveis e infectados. Este conceito foi aplicado por [77], que fundamentou a teoria do limiar e, posteriormente, explorada por [133] para tentar explicar a periodicidade das epidemias.

Há uma proporção mínima de suscetíveis, chamada de proporção crítica, a partir da qual é desencadeada uma epidemia. Nesta fase o aumento do número de infectados não se dá de maneira linear mas bruscamente. Um fato interessante que se observa após a epidemia é a existência de uma queda dos níveis da relação infectados/suscetiveis bem abaixo deste valor limiar.

$\mathrm{O}$ valor do limiar está intimamente ligado à estimativa de $\boldsymbol{R}_{\boldsymbol{0}}$, parâmetro que trataremos mais detalhadamente, no próximo capítulo.

\section{Ponto limiar ("breakpoint") para macroparasitas}

Trata-se de um fenômeno que ocorre na população de macroparasitas, também conhecido pelos ecologistas como efeito Alee (1991[6]). Numa população de organismos que necessitem de um estágio, onde obrigatoriamente deva ocorrer contato sexual fértil para que a reprodução se viabilize, poderão existir condições que dificultem tal processo. Estas condições podem se manifestar através de variáveis sociais, biológicas e ambientais.

Numa população, em que a densidade de parasitas seja muito baixa, próxima de seu ponto limiar, poderá ser levada à extinção, em decorrência de simples flutuações estocásticas. Por exemplo, numa população de macroparasitas com estágio sexual no hospedeiro definitivo, como o esquistossoma, uma erradicação da infecção poderia ser alcançada, a princípio, se pela influência de algum fenômeno, que poderia ser a média de carga parasitária mantida abaixo do ponto limiar, levando o sistema para esta situação de estabilidade. Esta é uma possibilidade interessante, onde se usa a vida sexual dos parasitas contra eles próprios.

É interessante observar que não seria necessário estar intervindo no $\boldsymbol{R}_{\boldsymbol{0}}$ para reduzi-lo a um valor abaixo do seu valor limiar, pois, nestas condições, a erradicação poderia ocorrer, mesmo $\operatorname{com} \boldsymbol{R}_{\boldsymbol{0}}>\mathbf{1}$.

\section{Nível crítico}

Foi um conceito definido por Ross, $1908^{[122,123]}$, para a malária, como sendo "o número mínimo de mosquitos em relação ao homem, maior que zero, 
necessário para a que a transmissão se mantivesse na comunidade, dada uma série de circunstâncias malariométricas." Estas circunstâncias malariométricas estariam levando em conta o tipo de vetor (mosquito), a população hospedeira, período extrínseco do parasita e as possíveis variáveis que estariam direta ou indiretamente associadas à transmissão da malária, dentro de uma comunidade. Este conceito será explorado mais detalhadamente no próximo capítulo.

\section{Abordagem quantitativa}

Para uma análise quantitativa do processo de infecção na população, tomaremos como base o modelo simples (figura 3) de três classes, considerando somente a idade como variável dependente, o que confere a ele a característica de um modelo compartimental estático. Caso o tempo também fosse considerado como variável dependente, o modelo adquiriria a característica de um modelo compartimental dinâmico, mais complexo em sua elaboração, porém mais rico em suas análises.

Figura 3. Modelo compartimental fechado

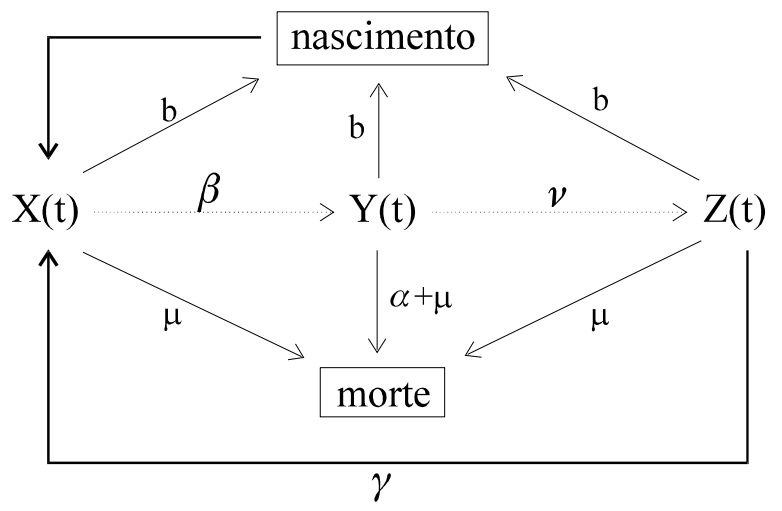

onde:

- $\quad \boldsymbol{X}(\boldsymbol{t})$ suscetíveis, $\boldsymbol{Y}(\boldsymbol{t})$ infectados, $\boldsymbol{Z}(\boldsymbol{t})$ imunes;

- $\quad \boldsymbol{b}$, taxa de natalidade

- $\quad \boldsymbol{m}$, taxa de mortalidade

- $\quad \alpha$, taxa de mortalidade induzida pela infecção,

- $\quad \beta$, coeficiente de transmissão da infecção, 
- $1 / v$, período médio de recuperação da infecção,

- $\quad \gamma$, taxa média de perda de imunidade.

Para uma análise mais simplificada, consideraremos que:

- $\quad \quad \quad N$, número total de indivíduos seja constante, o que vale dizer que a taxa de mortalidade, $\boldsymbol{m}$, seja igual à taxa de natalidade, $\boldsymbol{b}$;

- $\quad a$, a taxa de mortalidade associada à infecção seja igual a zero.

O que se observa para população humana é uma taxa de mortalidade em função da idade. Existem, no entanto, duas formas de mortalidade na população com características extremas (figura 4 ), que ajudam a simplificar as análises para o modelo. São elas:

\section{Tipo I}

Apresenta um ponto da idade $\boldsymbol{L}$, a partir do qual todos os indivíduos morrem, expressa matematicamente como:

$$
\begin{array}{ll}
\mu(a)=0 & \text { para } a<L \\
\mu(a)=\infty & \text { para } a>L
\end{array}
$$

onde $\boldsymbol{L}$ é a idade máxima de sobrevivência

\section{Tipo II}

Apresenta uma taxa de mortalidade constante, não variando com a idade, o que resulta em uma curva em decréscimo exponencial de sobrevida:

$$
\mu(\mathrm{a})=\mu=\text { constante inversamente proporcional a idade }(1 / \mathrm{L})
$$

onde L é a expectativa de vida da população. 
Figura 4. Curva de mortalidade Tipo I (B) e Tipo II (A)

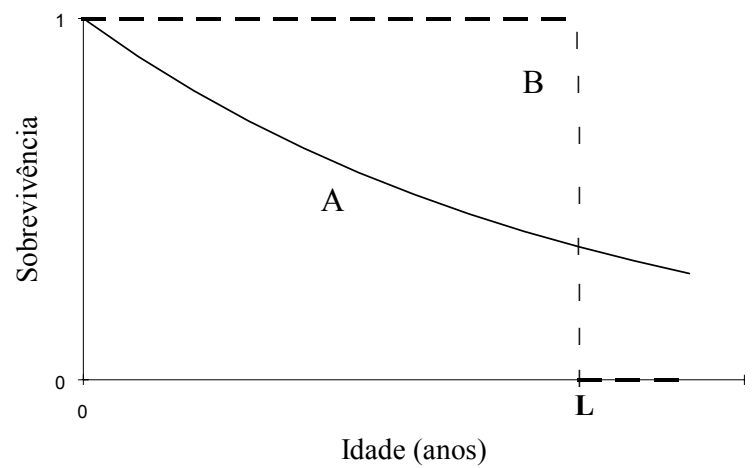

Nos países desenvolvidos, a mortalidade do tipo I, pode de forma grosseira, representar esta variável, enquanto nos países em desenvolvimento a curva que melhor representaria seria uma forma intermediária entre os tipos I e II.

Com estas hipóteses, a taxa de natalidade $\boldsymbol{b}$, pode ser expressa por:

$$
b=\int_{0}^{\infty} \mu(a) N(a) d a
$$

onde:

$$
N(a)=X(a)+Y(a)+Z(a)
$$

Para as duas formas de $\boldsymbol{m}$ (tipo I e II) a solução desta equação é:

$$
b=\frac{N}{L}
$$

No equilíbrio, a estrutura idade dependente das três classes pode ser representada pelo seguinte sistema de equações diferenciais, considerando $\boldsymbol{g}=\boldsymbol{0}$ :

$$
\begin{aligned}
& \frac{d X}{d a}=-[\lambda+\mu(a)] X(a) \\
& \frac{d Y}{d a}=\lambda X(a)-[v+\mu(a)] Y(a) \\
& \frac{d Z}{d a}=v Y(a)-\mu(a) Z(a)
\end{aligned}
$$


Somando-se este sistema de equações, temos:

$$
\frac{d N}{d a}=-\mu(a) N(a)
$$

Na condição de contorno, temos:

$$
\begin{aligned}
& X(0)=N(0) \text { e } Y(0)=Z(0) \\
& N(0)=\mu
\end{aligned}
$$

Integrando-se este sistema de equações lineares obtemos:

$$
N(a)=\mu l(a)
$$

onde $\boldsymbol{l}(\boldsymbol{a})$ é definido como a probabilidade de sobrevivência até a idade $\boldsymbol{a}$, dado por:

$$
l(a)=\exp \left(-\int_{0}^{a} \mu(s) d s\right)
$$

Onde o número de suscetíveis, idade específico, é dado por:

$$
X(a)=N(0) l(a) e^{-\lambda a}
$$

e a fração de hospedeiros, na idade $\boldsymbol{a}$, que são suscetíveis, é dada por:

$$
x(a)=\frac{X(a)}{N(a)}=e^{-\lambda a}
$$

As equações (14 e 15) podem ser generalizadas para $l(\boldsymbol{a})$, resultando no número de infectados e imunes respectivamente:

$$
\begin{aligned}
& Y(a)=\frac{\lambda N(0) l(a)\left(e^{-v a}-e^{-\lambda a}\right)}{(\lambda-v)} \\
& Z(a)=N(0) l(a)\left[1-\frac{\left(\lambda e^{-v a}-v e^{-\lambda a}\right)}{(\lambda-v)}\right]
\end{aligned}
$$

As análises deste modelo irão subsidiar a compreensão das etapas para se estimar $\boldsymbol{R}_{\boldsymbol{0}}$, no próximo capítulo. 


\section{Razão de Reprodutibilidade Basal $\left(\mathbf{R}_{\mathbf{0}}\right)$}

\section{Considerações gerais}

$\mathcal{C}$ omo foi exposto anteriormente, a Razão de Reprodutibilidade Basal, $\boldsymbol{R}_{\boldsymbol{0}}$, é um conceito que surgiu do desenvolvimento e aplicação dos modelos matemáticos. É essencialmente o número de descendentes viáveis que um parasita é capaz de produzir. Sua utilização é importante tanto no uso de modelos para macro como para microparasitas.

Para macroparasitas $\boldsymbol{R}_{\boldsymbol{0}}$ é definido como sendo o número médio de descendentes fêmeas produzidas durante toda a vida fértil do parasita, que conseguem, na ausência de fatores "densidade-dependente", atingir a maturidade reprodutiva (1991[6]). A definição para microparasitas, que é o objeto deste trabalho, será apresentado em mais detalhes a seguir.

\section{Definição de $R_{0}$ para microparasitas}

$\boldsymbol{R}_{\boldsymbol{0}}$ é definida como sendo o número de infecções secundárias que um único caso poderia produzir em uma população completamente suscetível $\left(1952^{[86]}\right)$.

A definição de $\boldsymbol{R}_{\boldsymbol{0}}$ não se refere ao número de casos secundários produzidos, mas sim da sua capacidade de gerar novos casos. 


\section{Histórico}

A variável $\boldsymbol{R}_{\boldsymbol{0}}$ foi inicialmente utilizada em demografia ("net reprodution rate") por Richard $1886^{[15]}$, em Berlim, para calcular o crescimento natural de uma população, o que ele chamou de propagação da população total. O método consistiu em utilizar a tábua de vida da população somando o produto das probabilidades de sobreviver no período fértil (idade compreendida entre 14 e 53 anos de idade), pela chance de se ter um nascimento do sexo feminino. Foi então obtido o número de recém-nascidos do sexo feminino, que representaria as mulheres que, ao longo de sua vida, estariam sujeitas às taxas de mortalidade e fertilidade específicas para cada idade.

A fórmula de cálculo de $\boldsymbol{R}_{\boldsymbol{0}}$ foi apresentada por Sharpe e Lotka em 1911 mas sem símbolos e nomes. Não se sabe precisar com certeza quando $\boldsymbol{R}_{\boldsymbol{0}}$ e "net reprodution rate" foram citados pela primeira vez. O que se sabe é que, somente em 1939, Lotka, em uma revisão apresenta a noção destes termos quando cita o trabalho de Böckh (1939 [84]), mastrando a vantagem do uso de $\boldsymbol{R}_{\boldsymbol{O}}$ para estimar a população, sem precisar da distribuição etária.

Considerando $\boldsymbol{p}(\boldsymbol{a})$ a probabilidade de uma mulher sobreviver até a idade $\boldsymbol{a}$ e $\phi(a)$ a taxa de nascimento de recém-nascidos do sexo feminino, para um indivíduo na idade $\boldsymbol{a}$, então a razão de reprodutibilidade basal é dado por:

$$
R_{0}=\int_{0}^{\infty} p(a) \phi(a) d a
$$

A primeira aplicação desta variável na área médica foi feita por George $1952^{[86]}$ para malária, o qual definiu $\mathrm{R}_{0}$ (Taxa de Reprodutibilidade Basal) como sendo o número de infectados gerados em uma comunidade suscetível, surgidos como resultado direto da presença de um único caso primário. No caso, o termo taxa (rate), para definir $\mathrm{R}_{0}$, não é bem empregado, por ser este um número adimensional, o termo razão (ratio) seria mais preciso (1993[45]).

A definição de $\boldsymbol{R}_{\boldsymbol{0}}$ por Macdonald foi posteriormente ampliada por 1964[131] que a usou para estudar a transmissão de doença por arbovírus. Foi quando, pela primeira vez, este conceito foi utilizado para estudar efeitos da vacinação na população. Ele estimou a proporção mínima de cobertura vacinal para controle da doença (propondo o cálculo através do inverso da proporção dos 
suscetíveis após uma epidemia). Posteriormente surgiram várias propostas para estimar-se $\boldsymbol{R}_{\boldsymbol{0}}$ que serão apresentadas neste capítulo.

\section{De que depende $R_{0}$ ?}

$\mathrm{R}_{0}$ é uma medida que depende fundamentalmente de 3 (tres) parâmetros:

- da taxa de contato;

- da duração do período de infecciosidade e

- da probabilidade de que o contato entre um infectado e um suscetível desenvolva a infecção, chamada de eficiência do contato. Este parâmetro por sua vez, depende de dois outros: a infectividade e a suscetibilidade.

Quando tratamos um modelo considerando heterogeneidades é obrigatório estabelecer a relação infectividade/susceptibilidade. Considerar heterogeneidades significa levar em conta diferentes taxas para variáveis que se julga participar de forma relevante no mecanismo de transmissão da doença estudada. Por exemplo, idade, constituição genética, hábitos, localização geográfica, entre outras.

\section{Valores de $R_{0}$ e seu significado}

$\boldsymbol{R}_{\boldsymbol{0}}$ é um número adimensional, assumindo valores não negativos.

A condição de $\boldsymbol{R}_{\boldsymbol{0}} \leq \boldsymbol{1}$ só pode existir teóricamente. Por exemplo, podemos estimar o valor de $\boldsymbol{R}_{\boldsymbol{0}}$ para uma comunidade $\mathbf{A}$ onde a doença não exista. Baseados em uma comunidade $\mathbf{B}$ onde a doença é endemica, e substituindo-se os valores dos parâmetros para a comunidade $\mathbf{A}$, então o valor de $R_{0}$ pode assumir um valor menor que 1. Isto indica que a doença nesta comunidade $\mathbf{A}$ não conseguiria se manter caso um organismo infectante fosse introduzido.

Para ilustrar este conceito, poderemos citar o exemplo da malária no Estado de São Paulo. Por que, apesar de existirem aparentes condições para a existência da doença na região, ela não assume os índices endêmicos encontrados no centronorte do país? Utilizando os parâmetros estimados em regiões do centro-norte, onde a malária é endêmica, e transportando-os para S.Paulo, considerando as características específicas desta região, pode-se estimar um valor teórico para $\mathrm{R}_{0}$. 
Este valor, segundo Yang, 19957, é menor que 1, isto é, caso surjam casos da doença, ela tenderá, em condições normais, a ser eliminada expontâneamente da comunidade. Para explicar este fato, usamos as seguintes suposições:

- o desmatamento da região, limitou o habitat do mosquito,

- a baixa temperatura do sul do país, não propicia um ambiente adequado para a sobrevivência do mosquito, o que traz como consequência um encurtamento na sua vida média. Para o desenvolvimento do parasita, é necessário um período de incubação interínsico no mosquito. Como a vida média do mosquito diminui, este período torna-se longo o suficiente para que a grande maioria de mosquitos morra antes de estar infectante, isto é, antes que a maturação dos parasitas em suas glândulas salivares ocorra, e desta maneira, poder ser infectante para o homem. Assim, mesmo que surjam casos da doença no sul, ela não consegue se manter.

- Neste exemplo em particular leva-se também em conta a intervenção no tratamento dos casos pela quimioterapia. Acredita-se, no entanto, que esta variável esteja atuando em menor proporção no controle da doença.

Com valor de $\boldsymbol{R}_{\boldsymbol{0}}<\boldsymbol{1}$ observa-se uma tendência do número de infectados cair para zero, desta maneira, um caso não consegue em média, gerar um outro. Então, numa situação de controle da doença, estaremos caminhando para a erradicação (ou extinção).

A condição de $\boldsymbol{R}_{\boldsymbol{0}}>\mathbf{1}$ representa a situação endêmica ou epidêmica de determinada doença. A magnitude de $\mathrm{R}_{0}$ permite avaliar o esforço necessário para se controlar esta doença numa comunidade, num determinado tempo.

Quando estimamos $\boldsymbol{R}_{\boldsymbol{0}}$, estamos avaliando a capacidade de intervir em uma comunidade a fim de se controlar uma doença, evitando uma epidemia ou diminuindo sua prevalência, no caso ideal levando seu índice ao valor zero. Tal índice é alcançado quando estamos diante de uma situação de erradicação ou eliminação da doença. No caso de eliminação de uma doença, estamos tratando de uma situação em que o equilíbrio é estável, isto é, toda a vez que sugirem casos da doença na comunidade, no máximo alguns poucos casos secundários iriam surgir,

${ }^{7}$ YANG H.M., FERREIRA M.U., (LIM01-FMUSP) Modelo Matemático Aplicado à Transmissão de Malária em Rondônia, trabalho em fase final de elaboração para ser submetido à publicação. 
havendo uma tendência a se voltar ao estado de prevalência zero. Quando nos referimos a erradicação, estamos diante de um equilíbrio instável, situação que implica na entrada de um caso infectante, predispondo uma epidemia, com grande número de casos. Temos na varíola o exemplo único de erradicação de uma doença e estamos muito próximos, pelo menos teoricamente, da erradicação da poliomielite $\left(1993^{[45]}\right)$.

A medida em que exista qualquer intervenção em uma comunidade, não é $\boldsymbol{R}_{\boldsymbol{O}}$ que diminui e sim a reprodutibilidade efetiva, R, que assumirá valores no máximo igual a $\boldsymbol{R}_{\boldsymbol{0}}$.

\section{Ro e medidas de controle}

A vantagem de se estimar $\boldsymbol{R}_{\boldsymbol{0}}$ para uma determinada doença numa comunidade, é poder ter uma idéia mais clara de como a doença se comporta durante uma determinada intervenção, e também de avaliarmos a magnitude deste comportamento. A partir desta variação é possível nortear uma medida de controle mais eficiente, isto é, qual seria a intervenção que traria melhor resultado, se aplicada naquela comunidade.

Através do $\boldsymbol{R}_{\boldsymbol{O}}$, poderemos também estar analisando uma situação de prevalência zero, assim como avaliarmos se estamos diante de uma situação de equilíbrio estável ou instável, o que iria permitir decidir por exemplo, sobre a manutenção ou não de um programa vacinal. Para exemplificar temos o caso da poliomielite.

Várias são as medidas de intervenção que podem ser adotadas em uma comunidade para controle de uma determinada doença. Cada doença apresenta variáveis específicas envolvidas no seu mecanismo de transmissão. A resposta a estas medidas dependerá de fatores inerentes à comunidade e à propria doença estudada. A medida de $\boldsymbol{R}_{\boldsymbol{O}}$ permite que seja dimensionado a participação de cada uma destas variáveis, e se forneça um instrumento importante para compreensão da dinâmica de transmissão.

Para ilustrar as aplicações deste instrumento, citaremos algumas das principais medidas de controle habitualmente utilizadas:

- diminuição de suscetíveis, como na vacinação; 
- diminuição da taxa de contato como na quimioterapia, eliminação de vetores, utilização de comdons nas DSTs, etc.

A vacinação atua principalmente na diminuição da susceptibilidade dos indivíduos da comunidade, e é apoiado nisto que iremos apresentar as diversas abordagens para o estudo desta intervenção. Cabe ressaltar também, que ela pode agir na redução da infectividade e do período de infecção. Várias seriam as alternativas com relação a abordagem deste estudo, como por exemplo determinar a menor cobertura vacinal necessária para se controlar uma determinada doença.

Usamos o $\boldsymbol{R}_{\boldsymbol{0}}$ para determinar a cobertura vacinal mínima necessária a ser alcançada em uma população para que se possa controlar a doença (erradicação ou eliminação). Neste caso, o mínimo de suscetíveis é o parâmetro que está sendo modificado.

O valor de $\boldsymbol{R}_{\boldsymbol{O}}$ poderá, também, permitir a avaliação de uma intervenção vacinal em uma comunidade, oferecendo subsídios que ajudem a prever a dificuldade que será enfrentada para o controle da doença e em que comunidade ela seria mais facilmente controlada.

Assumindo uma população homogênea, se $\boldsymbol{p}$ é a proporção de imunizados pela vacina $\operatorname{logo}$ ao nascimento, então temos em 1-p a proporção remanescente de suscetíveis nesta população. Acredita-se, no entanto, que este valor seja um pouco maior quando levamos em conta a imunidade adquirida, então temos $\boldsymbol{R} \leq \boldsymbol{R}_{\boldsymbol{0}}(\mathbf{1}-\boldsymbol{p})$.

A erradicação é obtida quando temos a situação $\boldsymbol{R}<1$. Então a proporção de imunizados para obter-se o controle da infecção $\left(\boldsymbol{p}_{\boldsymbol{c}}\right)$ na comunidade e dado por:

$p_{c}=1-\left(1 / R_{\emptyset}\right)$, pela figura 5 isso pode ser melhor visualizado, em áreas onde acontece a erradicação e outra onde a doença persiste. 
Figura 5. Nível crítico de cobertura vacinal necessária $\left(p_{C}\right)$ para obter 0 controle de uma infecção relacionado com o valor de $R_{0}$.

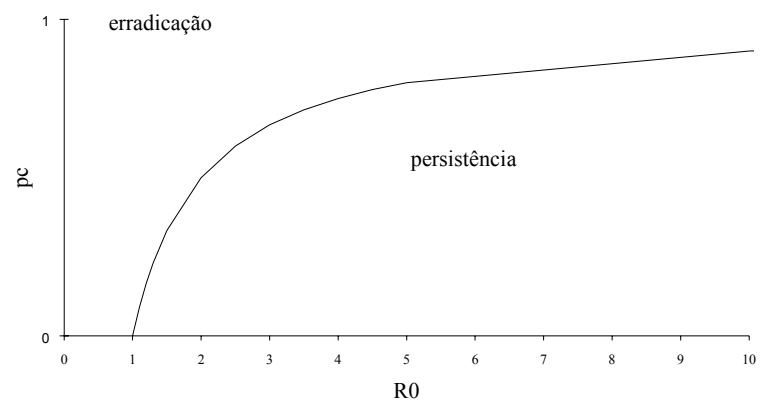

Esta vacinação efetiva $\boldsymbol{p}_{\boldsymbol{c}}$ pode ser conhecida estimando-se a idade média de aquisição da primeira infecção $\boldsymbol{A}$, pela relação $\boldsymbol{R}_{\boldsymbol{O}} \cong L / \boldsymbol{A}\left(1991^{[6]}\right)$.

Quando consideramos uma estratégia de controle do tipo quimioterapia, estamos interferindo na diminuição do período de infecção da infecção e desta maneira reduzindo a taxa de contato. A mudança de comportamento é outra estratégia onde também poderemos diminuir a taxa de contato e desta maneira reduzir o R efetivo da infecção.

\section{Métodos de estimação de $\boldsymbol{R}_{0}$}

Estimar $\boldsymbol{R}_{\boldsymbol{0}}$ é uma tarefa difícil, pois exite uma grande quantidade de fenômenos que interferem no mecanismo de infecção e entre eles os "densidadedependentes", que seriam variáveis relacionadas com as características populacionais do parasita ou da comunidade hospedeira. Portanto, estimar a influência destes fenômenos que mantêm o valor real de R, $\boldsymbol{R}$ efetivo, abaixo de sua capacidade intrínseca, isto é $\boldsymbol{R}<\boldsymbol{R}_{\boldsymbol{0}}$, é bastante complexo.

Quando uma infecção se estabelece em uma população hospedeira, a fração de sucetíveis decresce. O equilíbrio então, pode ser obtido quando, em determinado momento, um infectado consegue produzir em média uma infecção secundária, isto é o $\boldsymbol{R}$ do parasita passa a ser igual a 1. A partir destes conceitos, podemos apresentar várias alternativas para estimar este parâmetro. Iremos apresentar algumas delas, não pretendendo com isso, esgotar as alternativas existentes para estimá-lo. 


\section{A partir do número de suscetíveis}

Se considerarmos uma população homogênea, então o número de infecções secundárias produzidas por um infectado é linearmente proporcional à probabilidade de contatos efetivos com o suscetível (1991[6]). Neste caso temos:

$$
R=R_{0} x
$$

onde, $\boldsymbol{x}$ é a fração da população que é suscetível.

No equilíbrio, $\mathrm{R}=1$, então:

$$
R_{0} x^{*}=1
$$

onde $\mathrm{x}^{*}$ é a fração da população que é suscetível no equilíbrio e pode ser obtido a partir de dados epidemiológicos.

Geralmente $\boldsymbol{R}_{\boldsymbol{0}}$ não é uma função linear de $\boldsymbol{N}, \boldsymbol{R}_{\boldsymbol{0}}=\boldsymbol{f}(\boldsymbol{N})$ como por exemplo o sarampo na Inglaterra no período entre 1966-82 (1991[6]). Neste caso a função que melhor definiu este parâmetro foi: $R_{\boldsymbol{O}}=(\boldsymbol{N} / \mathbf{N} t)^{\boldsymbol{v}}$ com $\boldsymbol{v}<1$, onde $N \boldsymbol{t}$ representa a magnitude limiar. $\mathrm{O}$ aumento de $\boldsymbol{R}_{\boldsymbol{0}}$ para macroparasitas é também usualmente mais lento que o linear. No entanto o critério $\boldsymbol{R}_{\boldsymbol{0}}>\mathbf{1}$ parece válido para indicar a condição de ultrapassar o limiar deste parâmetro.

Obs: Exceção feita às doenças de padrão como da transmissão sexual e doenças associadas com transmissão por seringas e agulhas contaminadas onde a epidemia não depende de $\boldsymbol{N}$ e sim do comportamento dos indivíduos da população.

\section{A partir do período de duração da infecção}

Consideremos uma situação em que um agente se estabelece em uma comunidade de hospedeiros inteiramente sucetíveis. Tal situação pode ocorrer em duas situações:

- $\quad$ quando a população de hospedeiros nunca teve contato com este agente anteriormente ou,

- $\quad$ quando o agente estivesse ausente desta comunidade, tempo suficiente para que ela perdesse a imunidade específica obtida contra ele. 
No momento em que o hospedeiro infectante - o caso índice - entrar em contato com esta comunidade, o agente terá à sua frente uma situação bastante favorável, onde os fatores "densidade-dependentes" praticamente não interferem, permitindo, desta maneira, que a capacidade intrínseca deste agente seja explorada ao máximo.

Neste caso teríamos um crescimento exponencial de infectados, dado pela expressão (1991[6]):

$$
P(t)=P(0) \exp (\Lambda t)
$$

Onde:

$\mathrm{P}(\mathrm{t})$ é a população infectada no tempo t;

$\mathrm{P}(0)$ é a população infectada no tempo $0 \mathrm{e}$

$\Lambda$ é uma variável que depende de $\boldsymbol{R}_{\boldsymbol{0}}$ e do período $\boldsymbol{D}$.

O infectante, antes de morrer, consegue produzir $\boldsymbol{R}_{\boldsymbol{0}}$ infecções em um período $\boldsymbol{D}$ (tempo de duração de sua vida ou tempo de duração da infecção), então:

$$
\Lambda=\frac{\left(R_{0}-1\right)}{D}
$$

$\operatorname{logo}\left(\boldsymbol{R}_{\boldsymbol{0}}-1\right)$ infecções são acrescentadas neste intervalo de tempo $\boldsymbol{D}$, isto é, $\frac{R_{0}-1}{D}$ infecções por unidade de tempo.

Portanto, no tempo inicial, quando $D$ é conhecido, é possivel estimar-se $\mathrm{R}_{0}$. 


\section{A partir da proporção de suscetíveis, considerando-se a idade}

A partir de dados epidemiológicos estratificados por idade, para mortalidade do tipo II o número de suscetíveis, $\boldsymbol{X}^{*}$ e o número total de indivíduos, $N^{*}$ são respectivamente:

$$
X^{*}=\int_{0}^{L} X(a) d a
$$

e

$$
N^{*}=\int_{0}^{L} N(a) d a
$$

rearranjando a equação (20) temos:

$$
R_{0}=\frac{1}{x^{*}}
$$

onde a proporção de suscetíveis é dado por:

$$
x^{*}=\left(\frac{X^{*}}{N^{*}}\right)
$$

Para mortalidade do tipo I as integrais anteriores são válidas fazendo L $₫ ¥$

Os resultados destas estimativas são apresentados na tabela 3. 
Tabela 3. Valores estimados de R0 para várias infecções, de acordo com o local e período (1991[6]).

\begin{tabular}{|c|c|c|c|c|}
\hline infecção & & local & período & $\mathrm{R}_{0}$ \\
\hline \multirow[t]{3}{*}{ sarampo } & & Inglaterra & $1960-80$ & $11-14$ \\
\hline & & Baltimore EUA & 1943 & $7-8$ \\
\hline & & Países Baixos & $1970-80$ & $11-14$ \\
\hline \multirow{2}{*}{$\begin{array}{l}\text { poliomielit } \\
\text { e }\end{array}$} & & USA & 1955 & $5-6$ \\
\hline & & Países Baixos & 1960 & $6-7$ \\
\hline \multirow[t]{3}{*}{ HIV } & homossexuais & & & \\
\hline & masculinos & Inglaterra & $1981-85$ & $2-5$ \\
\hline & heterosexuais & Kampala Uganda & $1985-7$ & $10-11$ \\
\hline
\end{tabular}

Observa-se que os valores de $\boldsymbol{R}_{\boldsymbol{0}}$ podem variar consideravelmente para diferentes doenças infecciosas, e também na mesma doença infecciosa para diferentes populações.

\section{A partir do primeiro tempo de duplicação de casos}

Através de dados de soroprevalência obtidos no início de uma epidemia, pode-se obter o valor do primeiro tempo de duplicação de casos $\left(\boldsymbol{t}_{\boldsymbol{d}}\right)$, ajustando: $Y_{(t d)}=2 Y_{(0)}$.

Através da expressão:

$$
R_{0}=\left[\frac{\ln (2)}{(\mu+\gamma) t_{d}}+1\right]
$$

onde:

- $\quad \boldsymbol{m}$ é igual à taxa de mortalidade natural

- $\quad g$ é o inverso do período de infecção

Este valor foi estimado por 1994[91], para a dengue, em São Paulo e, obtido um valor de $\boldsymbol{R}_{\boldsymbol{0}}=2,03$.

Aplicado para a comunidade gay da cidade de São Francisco, EUA, onde estimou-se um valor de $\boldsymbol{R}_{\boldsymbol{O}}=19,7$ (1991[71]) 


$$
\mathrm{R}_{0}=1+\frac{\mathrm{D} \ln 2}{\mathrm{t}_{\mathrm{d}}}
$$

onde

$\mathrm{D}=$ duração do periodo de infecção

$\mathrm{t}_{\mathrm{d}}=$ tempo de duplicaçao inicial

\section{A partir da força de infecção l}

É interessante fazer uma relação analítica entre $\boldsymbol{R}_{\boldsymbol{0}}$ (que caracteriza a infecção em seu estado fundamental) e $\boldsymbol{l}$ (derivada quantitativa, medida diretamente) através de varias hipóteses sobre a mortalidade:

Para o tipo I

$$
\begin{aligned}
& l(\mathrm{a})=1 \text { para } \mathrm{a}<\mathrm{L} \\
& l(\mathrm{a})=0 \text { para } \mathrm{a}>\mathrm{L}
\end{aligned}
$$

da equação (12) fazendo $N(\boldsymbol{a})=\boldsymbol{N}(0)$ até $\boldsymbol{a}=\boldsymbol{L}$ e zero acima deste valor, temos:

$$
N=N(0) L
$$

substituindo $X$ na equação (13) na equação (23) temos:

$$
X^{*}=\frac{N(0)\left(1-e^{-\lambda L}\right)}{\lambda}
$$

A estimativa de $\boldsymbol{R}_{\boldsymbol{O}}$ para mortalidade tipo I, que é uma boa aproximação para países desenvolvidos, é dada por:

$$
R_{0}=\frac{\lambda L}{1-e^{-\lambda L}}
$$

se temos $\boldsymbol{l} \boldsymbol{L}>>\boldsymbol{1}$ antes da imunização, uma excelente aproximação é dada por:

$$
R_{0}=\lambda L
$$

Para o tipo II

A partir da equação (13), a equação de $\boldsymbol{R}_{\boldsymbol{0}}$ é mais simples. Temos:

$$
l(a)=\exp (-\mu a)
$$




$$
\begin{aligned}
& N^{*}=\frac{N(0)}{\mu} \\
& X^{*}=\frac{N(0)}{(\lambda+\mu)} \\
& R_{0}=1+\frac{\lambda}{\mu} \\
& \text { se } \boldsymbol{m}=\mathbf{1} / \mathbf{L} \text { então, } \\
& R_{0}=1+\lambda L
\end{aligned}
$$

\section{A partir no tamanho final de uma epidemia}

1964[131] propôs estimar $\boldsymbol{R}_{\boldsymbol{O}}$ através do inverso da proporção de suscetíveis depois de terminada uma epidemia. Como exemplo, usou a epidemia de febre amarela urbana, que foi controlada quando $48-65 \%$ da população tornou-se imune, estimando $\boldsymbol{R}_{\boldsymbol{0}}$ entre 2 e 3 .

$$
R_{0}=\left(1-u_{\infty}\right) \ln u_{\infty}^{-1}
$$

$\mathrm{u}_{\propto}=$ proporção dos susceptiveis após o término da epidemia.

Esta fórmula poderia ser melhorada levando-se em conta a proporção de indivíduos previamente imunizados antes da epidemia (1987[67]).

\section{A partir de uma situação de equilíbrio}

Como mencionamos acima, a definição de $\boldsymbol{R}_{\boldsymbol{0}}$ não depende da imunidade alcançada após o período de infecção. $\mathrm{O}$ conceito é baseado em uma situação hipotética onde um indivíduo infectante é introduzido numa população inteiramente suscetível. Na prática esta é uma situação muito rara de ser encontrada, sendo, no entanto, mais comum encontrarmos uma situação de equilíbrio onde a doença já ocorra.

Observa-se, no entanto, que o equilíbrio é regulado por uma variável densidade dependente que ocorre no processo de transmissão devendo, portanto, ser muito bem conhecida.

\section{A partir de dados de prevalência em idade específica}

$\mathrm{Na}$ epidemiologia de doenças infecciosas os dados estimados são usualmente de estudos transversais de populações.Tem o objetivo de determinar a 
idade específica da prevalência de anticorpos com respeito à infecção passada. Isto significa que, quando encontramos um soropositivo, poderemos dizer que ele teve uma infecção numa idade menor que a atual, e, se a sorologia for negativa poderemos dizer que para este indivíduo a idade de infecção pode vir a ser maior que a atual. Dietz (1975[43]) demonstrou que a força de infecção está relacionada com $\boldsymbol{R}_{\boldsymbol{0}}$ da seguinte forma:

$$
\lambda=\mu\left(R_{0}-1\right)
$$

Onde $\mu$ é a taxa de mortalidade natural da população, e $\lambda$ é a força de infecção. Neste modelo é considerado uma taxa constante de mortalidade natural, e uma força de infecção idade independente. Isto significa que o $\boldsymbol{R}_{\boldsymbol{O}}$ pode ser estimado pelo produto da expectativa de vida e a força de da infeção somando unidade.

Se a força de infecção é idade dependente, então isto reflete heterogeneidade nas taxas de contatos entre os diferentes grupos etários (1993[36]). Em princípio esta taxa de contato não pode ser mensurável para o cálculo de $\mathrm{R}_{0}$. Nós deveríamos conhecer os elementos da matriz de contatos se discretizarmos a população em números finitos, no estrato idade. Anderson \& May ${ }^{[6]}$ estudaram várias hipóteses sobre a estrutura desta matriz. No entanto, tais considerações apontam para o fato de que $\boldsymbol{R}_{\boldsymbol{0}}$ não pode ser simplificado pelo inverso da proporção de suscetíveis da população. Esta forma deixa um problema estatístico de estimação da força de infecção, com base no grupo de dados onde as observações foram censuradas. Recentemente foi apresentado um método não paramétrico para hepatite A na Bulgária ( 1991[76]) para estimar a prevalência idade específica e a correspondente força de infecção, onde se obteve o valor de $\boldsymbol{R}_{\boldsymbol{0}}=3,8$.

\section{A partir de dados de parâmetros individuais}

Esta é uma forma bastante restrita para a estimação de $\boldsymbol{R}_{\boldsymbol{0}}$, usado para doenças de transmissão por vetores ou doenças sexualmente transmitidas (DSTs). Apesar desta aplicação ser restrita, ela é de relevante importância quando pretendemos analisar situações onde a doença ainda não exista. Entretanto ela tem todos os componentes para resultar numa epidemia, caso um agente infectante seja introduzido na comunidade. 
Como foi dito anteriormente, $\boldsymbol{R}_{\boldsymbol{0}}$ não pode ser estimado para uma população em que não exista a doença. No entanto para doenças transmitidas por vetores e DSTs, variáveis que não dependem do agente podem ser medidas:

- variáveis entomológicas: quantidade de picadas no homem por unidade de tempo, número de vetores contactando o homem por unidade de tempo, duração da parasitemia, etc.

- para DSTs o número de novos parceiros por pessoa por unidade de tempo e o número de contatos por parceiro.

\section{$R_{0}$ para malária}

A partir do modelo desenvolvido por $1956^{[88]}$, onde são envolvidos os seguintes parâmetros: m o número de mosquitos fêmeas por hospedeiros humano; $\mathbf{k}$ o número de picadas efetuadas por uma fêmea em um dia para alimentar-se (isto envolve a taxa de alimentação e a probabilidade de picar um hospedeiro humano). No mosquito existe um período de latência $\mathbf{I}_{2}$ (período extrínseco) que é necessário para desenvolver os esporozoítos depois do mosquito ter sido infectado pelo gametócito. Devido a alta taxa de mortalidade $\mu_{2}$, somente uma pequena fração $\exp \left(-\mu_{2} \mathbf{I}_{2}\right)$ sobrevive este período de latência. Se $\mathbf{D}_{\mathbf{1}}$ é o período de infecciosidade no hospedeiro humano e $\mathbf{D}_{\mathbf{2}}$ a duração do período de infecciosidade no vetor, $\mathbf{h}_{\mathbf{1}} \mathrm{e}$ $\mathbf{h}_{\mathbf{2}}$ as probabilidades de uma inoculação infectante em um indivíduo suscetível por um mosquito infectado e vice versa, respectivamente, temos:

$$
R_{0}=\sqrt{m k D_{1} h_{2} e^{-\mu_{2} / 2}\left(k D_{2} h_{1}\right)}=\sqrt{m k^{2} e^{-\mu_{2} / 2} D_{1} D_{2} h_{1} h_{2}}
$$

É interessante observar que com exeção do $\mathbf{D}_{\mathbf{1}}$ todos os outros parâmetros são determinados através de medidas entomológicas onde, $1964^{[58]}$ introduziram o conceito de capacidade vetorial para o produto (citado no capítulo anterior):

$$
\mathrm{CV}=\mathrm{mk}^{2} \mathrm{e}^{-\mu_{2} \gamma_{2}} \mathrm{D}_{2}
$$

É muito difícil estimar-se valores exatos para $\boldsymbol{R}_{\boldsymbol{0}}$ baseados em parametros individuais para malária, porém esforços para estimar-se a $\boldsymbol{C} \boldsymbol{V}$ ajudam a fornecer subsídios para explicar diferenças entre a prevalência e incidência de malária em diferentes locais.

A estimativa de $\boldsymbol{R}_{\boldsymbol{0}}$ pode ajudar no sentido de avaliar-se diferentes efeitos de medidas de controle, isto é, a redução da densidade de mosquitos sem afetar a 
sobrevivência (uso de larvicidas) e a redução da sobrevivência do mosquito (uso de adulticidas).

$$
m=v_{2} D_{2}
$$

larvicidas podem reduzir $\mathbf{v}_{\mathbf{2}}$ (número de novas fêmeas por homem, por tempo) e adulticidas podem reduzir $\mathbf{D}_{2}$, a expectativa de vida do vetor, quando analisamos a redução $\mathbf{r}$

$$
R^{*}=r v_{2}=r_{D_{2}}^{2} \exp \left[\mu_{2} I_{2} \boldsymbol{C}_{D_{2}}-1 \mathbf{g}\right.
$$

Observa-se que para uma redução de 50 e $75 \%$ da expectativa de vida do mosquito $\left(\mathbf{D}_{\mathbf{2}}\right)$ tras uma redução de 90 e 95,5\% da densidade de mosquitos, portanto muito mais sensível à redução das formas adultas. Através deste modelo pode-se observar a vantagem de um método sobre o outro. Esta é a mais simples e importante aplicação em saúde pública para doenças de transmissão por vetores, nas quais os modelos que ajudam na escolha de uma estratégia de controle $\left(1993^{[45]}\right)$.

Levanta-se no entanto 2 pontos com respeito a isto, e aos modelos em geral $\left(1985^{[104]}\right)$ :

- A identificação do ponto fraco de um sistema onde se deve concentrar os esforços, no sentido de controlar uma doença na comunidade, não segue automaticamente a análise da sensibilidade, obviamente depende também de outros fatores, como por exemplo, o custo.

- Os modelos geralmente consideram uniformidade, o que na realidade não ocorre, e acaba se traduzindo em um exagerado otimismo das medidas.

\section{$R_{0}$ para AIDS}

A epidemia de AIDS tem estimulado o desenvolvimento de modelos para moléstias infecciosas. Na Europa o número de casos de AIDS são atribuídos principalmente à transmissão sexual, com pequena contribuição dos IDUs $\left(1991^{[41]}\right)$.

$$
R_{0}=\frac{h C N}{[h C+(1-h) N]}
$$

onde $\mathbf{h}=$ probabilidade de infecção por contato 
$\mathbf{C}=$ número total de contatos com parceiro suscetível durante o período de infecciosidade

$\mathbf{N}=$ número de parceiros

Analisando-se a redução dos vários parâmetros observa-se que a medida mais efetiva está na redução de $\boldsymbol{R}$. Se $\mathrm{N}>\mathrm{hC}$, o uso de condoms é mais eficiente e se $\mathrm{N}<\mathrm{hC}$ reduzir quantidade de parceiros seria mais eficiente.

Este modelo têm como parâmetros, o número de parceiros por unidade de tempo, o número de contatos durante o período infecciosidade e a probabilidade de infecção por contato. Mostra que para $\mathrm{h}=0,2 \%$, e $\mathrm{C}=1000$ (100 contatos por ano por 10 anos) somente 2 parceiros diferentes neste período de 10 anos são necesssários para manter $\boldsymbol{R}_{\boldsymbol{0}}>\mathbf{1}$.

\section{Conclus̃̃es}

Apesar do conceito de $\boldsymbol{R}_{\boldsymbol{0}}$ ser conhecido há muitos anos, somente nos últimos 20 anos surge como um importante instrumento no estudo do controle e da dinâmica de transmissão das doenças infecciosas. A sua aplicação é bastante difícil, porém cada vez mais, sua utilização vem se tornando imprecindível como ferramenta, por vezes única, de escolha e avaliação de medidas de controle. 


\section{Objetivas}




\section{Gerais}

Estudar a dinâmica de transmissão do HIV e infecções de transmissão correlatas, em uma comunidade de usuários de drogas injetáveis, na cidade de Santos, São Paulo, Brasil. 


\section{Específicos}

1. Estimar a soroprevalência de HIV, hepatites B e C, HTLV (1 ou 2) e sífilis para uma amostra de UDIs da cidade de Santos;

2. Estimar a soroprevalência de HIV, hepatites B e C, HTLV (1 ou 2) e sífilis para uma amostra de doadores de sangue desta mesma cidade;

3. Estimar as contribuições relativas às formas de transmissão parenteral e sexual do HIV nestas infecções através da comparação das soroprevalências destas duas amostras;

4. Estimar as contribuições relativas aos hábitos sexuais e ao uso de drogas injetáveis na infecção pelo HIV no grupo de UDIs;

5. Estimar a variável comportamental mais significativa como fator de proteção contra estas infecções,

6. Estimar a razão de reprodutibilidade basal do HIV, nesta amostra de UDIs, através de cálculos baseados num modelo matemático elaborados por Macdonald para anofelíneos, adaptado por Massad e cols. para "agulhas".

7. Estimar, através deste modelo, a prevalência do HIV no equilíbrio para esta amostra. 


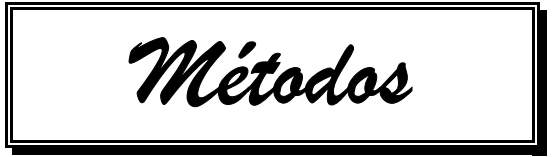




\section{População alvo}

S antos é uma cidade portuária, localizada a sudeste do Estado de São Paulo. Tem uma área de $725 \mathrm{~km}^{2}$, correspondendo a 0,29\% da área do Estado, dista $72 \mathrm{~km}$ da cidade de São Paulo, 13 km da cidade do Guarujá, 61 km da cidade de Itanhaém e 81 km de Peruíbe.

No ano de 1992, período deste estudo, contava com uma população estimada em 427.909 habitantes. É uma comunidade jovem, com 33\% dos indivíduos abaixo dos 19 anos de idade. Apresenta características essencialmente urbana, com somente 0,05\% de zona rural. ( 1990[127]). O serviço de saúde local é também extendido para outras pequenas cidades vizinhas da mesma região (8 no total, elevando com isto o número da população assistida para 1.500 .000 habitantes).

Por tratar-se de uma cidade portuária, onde se localiza o maior porto da América Latina e, consequentemente, o mais importante dos portos brasileiros, ela faz parte de rotas marítimas nacionais e internacionais permitiindo, desta maneira, acesso às mais importantes cidades brasileiras e estrangeiras. Além disto, aparece como uma importante rota do narcotráfico na América do Sul, uma das razões para a presumida alta prevalência de uso de drogas na cidade.

A comunidade de UDIs na cidade de Santos é caracterizada pelo hábito intenso no uso de droga injetável, como a cocaína (1993[113]). Como o efeito da cocaína é particularmente fugaz, a taxa média diária de injeção da droga é maior que as observadas em grupos que se utilizam da heroína como droga de preferência (1989[33]). No entanto, em comunidades como Santos, a prevalência esperada da infeçcão pelo HIV é particularmente alta, baseados em dois pontos principais: a proporção do uso de cocaína injetável ser alta - 92\% (1993[113]), e o fato de não existirem, aí implantados, estratégias efetivas de controle da infeçcão. 
Os primeiros casos de AIDS em Santos ocorreram em 1984, quando quatro casos foram diagnosticados, sendo um deles usuário de droga injetável (1984[16]). Desde então, a transmissão do HIV, por droga injetável, tem se apresentado como um problema crescente. Desde 1987, a AIDS passou a representar o maior problema de saúde para as autoridades locais de saúde, a tal ponto que lá foi montado o primeiro serviço para atendimento específico de AIDS da região. Análises recentes dos dados de saúde, mostram que o uso de drogas injetáveis foi responsável por 52\% de todas as infecções pelo HIV (1994[18]). Com um total de 1636 casos de AIDS registrados de janeiro de 1985 a janeiro de 1994, Santos possui o maior coeficiente de incidência de AIDS do Brasil - 353,2 casos por 100.000 habitantes $(1994[20])$.

Em 1991, foi iniciado em Santos uma pesquisa, como parte do Estudo Multicêntrico entre UDIs coordenado pela OMS, envolvendo 13 cidades no mundo ${ }^{8}$, compreendendo comportamento e soroprevalência do HIV (1993[113]). Estima-se que a população de UDIs da cidade compreende cerca de $2 \%$ da população geral, isto é, aproximadamente 10.000 indivíduos (1993[113]).

As leis brasileiras relacionadas com as drogas são bastante rígidas e desatualizadas (datada de 1976), dificultando a implementação de estratégias de controle das infecções causadas por este tipo específico de transmissão. É o caso do programa de trocas de seringas e agulhas entre os usuários de drogas, que, apesar de polêmico, é utilizado em outros países. Desta maneira, o serviço de saúde do município não tem qualquer poder de barganha para lidar com este tipo de lei, embora, com relação a trocas de seringas e agulhas, existam, em tramitação no Congresso Nacional, dois projetos de lei que contemplam este ítem.

As leis atuais permitem a compra e posse de seringas e agulhas, materiais estes que podem ser adquiridos em farmácias a baixo custo ( 0.20 dólares), ainda que os UDIs prefiram utilizar seu dinheiro na compra da maior quantidade possível de droga, na maioria das vezes, economizando este item.

A distribuição de condoms em Santos, embora melhor que no resto do país, tem a grande falha de não ser continuada, devido às recorrentes crises econômicas nacionais, que prejudicam a manutenção de estoques.

${ }^{8}$ WHO Multicentric Study compreende as seguintes cidades - Atenas, Bangcoc, Berlin, Glasgow, Londres, Madrid, Nápoles, Nova Iorque, Rio de Janeiro, Roma, Santos, Sidney e Toronto. 
Em contraste com o esforço das autoridades municipais de saúde em melhorar as medidas de prevenção contra o HIV, estratégias específicas de controle dirigidas aos usuários de drogas injetáveis (UDIs) têm sido timida e precariamente implantadas, fato este observado, também, no resto do país. Apenas em 1994, foi iniciado, no município, como estratégia de controle, um programa de distribuição de materiais de limpeza de seringas e agulhas, época em que a fase de coleta de dados deste estudo já havia terminado.

O tratamento de drogados está restrito a instituições religiosas e clínicas privadas, que são caras e, por isso, não são acessíveis à maioria dos UDIs. Como regra geral, o usuário de drogas é menos discriminados em Santos que no resto do país, embora essa discriminação exista quando o UDI é portador do HIV.

$\mathrm{Na}$ cidade de Santos existe a atuação de diversas Organizações Não Governamentais (ONGs) interessadas em HIV/AIDS (seis no total), mas apenas uma delas o Instituto de Estudos e Pesquisas de AIDS de Santos (IEPAS) dedica a maior parte de seus esforços ao usuário de drogas.

\section{Outras considerações acerca da cidade}

Os dados aqui apresentados, referem-se às informações obtidas para o ano de 1991, quando foi elaborado o projeto de pesquisa deste trabalho, seguido da apresentação e aprovação pela FAPESP (proc. 92/3419-4), na mesma época. A intenção de apresentá-los aqui, sem atualização, é mostrar uma noção acerca da cidade na época do estudo. Apesar disso, acredita-se que poucos destes valores tenham se alterado de maneira expressiva a ponto de alterar o contexto deste trabalho.

\section{Distribuição por faixa etária}

A distribuição da população por faixa etária apresenta características de países em desenvolvimento, com tendências de estreitamento da sua base, e alargamento nas faixas etárias mais avançadas, o que significa, a grosso modo, aumento da expectativa de vida, isto é, as pessoas estão conseguindo cada vez mais atingir faixas etárias mais avançadas. Não há discrepância muito grande entre os $\operatorname{sexos}(1990[70])$. 


\section{Indicadores de saúde}

Citaremos os valores de alguns dos principais indicadores de saúde, por ocasião do estudo 1990[127]:

- taxa de natalidade

- coeficiente de mortalidade infantil

- Coeficiente de Mortalidade Perinatal

- Coeficiente de Mortalidade Neo natal

- Natimortalidade

- Coeficiente de Mortalidade Geral
16,73 nasc. vivos/1000 habitantes;

$\mathbf{2 9 , 8 3}$ óbitos em $<1$ ano/1000 nasc.vivos

23,55 óbitos/1000 nascidos vivos.

17,42 óbitos/1000 nasc.vivos.

$\mathbf{6 , 2 7}$ óbitos/1000 nasc.vivos.

8,68 óbitos/1000 habitantes.

\section{Mortalidade proporcional}

O índice de Swaroop - Uemura (mortalidade proporcional para maiores de 50 anos) evoluiu de 57,54\% em 1970 para 69,05\% em 1980 e 75,39\% em 1988. Observa-se, porém, que, em 1989, houve uma queda para $71,74 \%$, com um aumento proporcional na faixa de 20 a 49 anos. Isto revela, mesmo que isoladamente, uma deteriorização nas condições de vida, pois aumentou a incidência de óbitos em faixas produtivas da população, fato este não esperado em condições ideais ( 1990[127]).

\section{Curva de mortalidade proporcional}

A curva de mortalidade proporcional (figura 6) apresenta-se com o mesmo aspecto desde 1984, representando uma configuração em "jota", isto é, de boa qualidade de saúde - NIVEL IV ( 1990[127]). 
Figura 6. Curva de mortalidade proporcional de Santos, 1984.

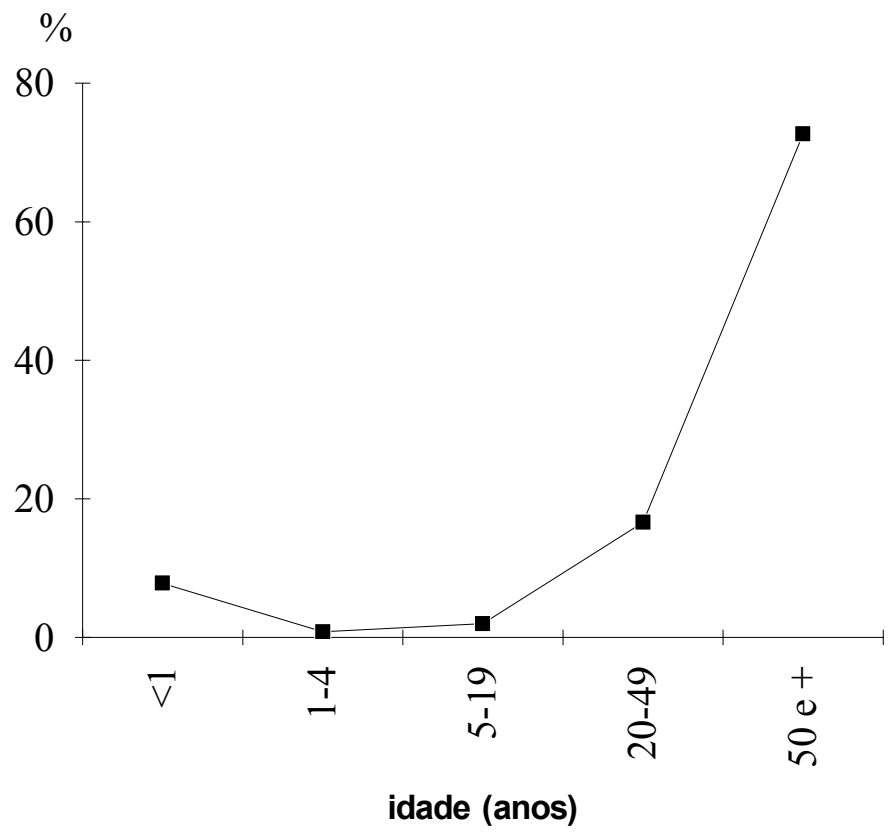

Fonte: $1990[127]$

\section{Perfil de morbidade}

Há dificuldade na obtenção de dados sobre a morbidade, pela falta de um sistema eficiente de registro e coletas de dados ambulatoriais, situação esta não reservada exclusivamente a cidade de Santos. A alternativa encontrada foi a obtenção de dados referentes às internações hospitalares e registros da vigilância epidemiológica, que são mais confiáveis.

O perfíl de morbidade de Santos, no período de julho de 1987 a junho de 1988, baseado em informações de internações hospitalares e dados da vigilância epidemiológica, é apresentado na tabela 4. 
Tabela 4. Morbidade hospitalar de Santos no período de julho de 1987 à junho de 1988.

\begin{tabular}{llrr}
\hline ordem & grupo de doenças & número & $\%$ \\
\hline $1 \underline{\text { o }}$ & doenças do aparelho circulatório & 866 & 16,09 \\
$2 \underline{\text { o }}$ & comp. gravidez, parto e puerpério & 729 & 13,05 \\
$3 \underline{\underline{0}}$ & lesões e envenenamentos & 548 & 10,50 \\
$4 \underline{\text { o }}$ & doenças do aparelho digestivo & 537 & 9,99 \\
$5 \underline{\text { o }}$ & doenças do aparelho respiratório & 477 & 8,87 \\
$6 \underline{\text { o }}$ & neoplasias & 376 & 6,99 \\
$7 \underline{0}$ & doenças do aparelho genito-urinário & 355 & 6,60 \\
$8 \underline{\text { o }}$ & doenças infecto parasitárias & 227 & 4,22 \\
$9 \underline{\text { o }}$ & outros & 1215 & 23,69 \\
\hline total & & 5350 & 100,00 \\
\hline
\end{tabular}

Fonte: $1991^{[17]}$

Nota-se que a morbidade hospitalar segue padrões de países desenvolvidos, destacando-se, ainda, o grupo das lesões e envenenamentos, que, no Brasil, ocupa o $8^{\circ}$ lugar e, em Santos, o $3^{\circ}$ lugar (1990[70]).

\section{Migração}

A população de Santos é composta quase que 50\% de migrantes, dos quais apenas 5\% não são brasileiros (1990[70]). Atualmente, (tabela 5) a maioria dos migrantes está há mais de 10 anos na cidade (61\%), mostrando que a migração vem diminuindo nos últimos anos. 
Tabela 5. Tempo de migração a partir de 1980 na cidade de Santos.

\begin{tabular}{lrr}
\hline tempo de migração & indivíduos & $\%$ \\
\hline$<1$ ano & 15.015 & 7,47 \\
1 a 5 anos & 36.550 & 18,19 \\
6 a 9 anos & 22.853 & 11,38 \\
$>10$ anos & 122.580 & 61,03 \\
s/decl. & 3.874 & 1,93 \\
\hline total & 200.872 & 100,00 \\
\hline
\end{tabular}

Fonte: $1990^{[70]}$

\section{Grau de instrução}

A relação entre a população escolarizada e não escolarizada (maior de 10 anos) era de 1/3 (76,56) no ano de 1980 (1990[70]). Na distribuição dos escolarizados, 52,8\%, um índice muito alto, de pessoas com formação apenas elementar.

\section{Rendimento médio mensal}

Em 1980, 40\% das famílias tinham rendimento médio de 5 salários mínimos mensais, o que resultava em uma renda média de 1,6 salários mínimos "per capita", demonstrando que grande parcela da população vivia em condições bastante precárias $(1990[70])$. Se considerarmos que, na última década, foi observada uma diminuição do poder aquisitivo do salário mínimo e um achatamento salarial no país como um todo, conclui-se que, em 1990, a cidade de Santos possuia uma quantidade ainda maior de famílias com rendimento menor que 5 salários mínimos, uma população, portanto, ainda mais empobrecida.

\section{População economicamente ativa}

No ano de 1980 , em torno de $40 \%$ da população total do município estava incluída em atividades econômicas, sendo $70 \%$ deste contingente pertencente a setores da indústria, comércio e prestação de serviços (1990[70]). 


\section{Saneamento básico}

O sistema de abastecimento de água atende $100 \%$ da população fixa e flutuante da cidade de Santos. No distrito de Bertioga, região também atendida pelo serviço de saúde do município, o abastecimento atende apenas $81 \%$ da população fixa e $36 \%$ da flutuante.

O sistema de esgoto sanitário apresenta uma situação diferente. Ele atende $80 \%$ da população fixa de Santos e inexiste em Bertioga . Os $20 \%$ sem esgoto estão localizados em bairros da zona noroeste, nos morros e na área do porto.

\section{Serviços de saúde}

A cidade de Santos apresenta um serviço de saúde público que conta com uma rede básica de saúde, ambulatório de especialidades, serviços de apoio especializados (ECG, audiometria, ciclometria, anatomia patológica, radiologia, colposcopia, laboratórios de análises clínicas), unidade de reabilitação, serviço de pronto socorro, serviço hospitalar, centro de controles de doença, serviços de combate a pragas (anti-rábica animal e humana, desratização,etc), serviço de fiscalização da higiene pública, serviços de perícia médica

O atendimento à saúde está apoiado basicamente no setor público.

\section{Considerações gerais}

Ao analisarmos os dados aqui relatados, observamos que a cidade de Santos não apresenta números conflitantes e apontam para uma cidade com um bom nível de saúde, situação bastante privilegiada, quando comparada com todo o resto do país. Porém, quando nos deparamos com os dados referentes à AIDS, esta situação privilegiada deixa de existir e aponta para números bastante preocupantes, como foi descrito anteriormente, o que nos levou a elegê-la como local para este estudo. 


\section{Amostra}

A

amostra foi composta por 197 UDIs (118 homens e 79 mulheres) recrutados nas ruas e clínicas de tratamento, no período de abril de 1991 a dezembro de 1992, através do método de recrutamento de "bola de neve" ("snow-balling"). Este método consiste em trazer para o estudo através de um caso índice, outros casos que com ele se relacionam. Estes, por sua vez, trazem outros também relacionados entre si e, assim por diante, o que nos permite, ao final, compor uma rede de indivíduos que, de forma direta ou indireta, se relacionam. A escolha desta técnica amostral baseou-se na grande dificuldade de acesso a este tipo de indivíduo, tanto do ponto de vista pessoal e, principalmente, do ponto de vista legal. Os critérios de inclusão no estudo foram:

- ter feito uso de drogas injetáveis nos últimos 6 meses,

- apresentar idade igual ou superior a 18 anos e,

- após ser esclarecido sobre o estudo, fornecer um consentimento formal para poder dele participar.

A soroprevalência da população geral das infecções estudadas em Santos foi obtida de uma amostra de doadores de sangue, pareados por sexo e idade, com a amostra obtida de UDIs, no mesmo período da coleta de dados. A cidade possui um único banco de sangue que se responsabiliza pela triagem sorológica do sangue coletado, que são também provenientes de outros postos de coleta. Esta coleta passa por uma triagem anterior, através de entrevistas, com a intenção de eliminar indivíduos com história de risco para doenças de transmissão parenteral e sexual. 


\section{Coleta de dados}

Os indivíduos participantes no estudo foram entrevistados através de dois questionários (anexo III e IV), o primeiro, que era essencialmente o mesmo utilizado no estudo multicêntrico (1993[113]), consistindo de nove secções, compreendendo 185 questões divididas nas seguintes partes:

i)identificação e informações pessoais;

ii)características demográficas,

iii)hábitos em relação ao uso de drogas injetáveis;

iv)compartilhamento de seringas e "agulhas" e fatores de risco para infecção pelo HIV;

v)comportamento sexual;

vi)Conhecimento sobre AIDS e mudança de comportamento;

vii)história de viagens;

viii)teste de HIV e

ix)fatores determinantes de intensidade de transmissão.

O segundo questionário (anexo IV), compreendendo questões exclusivas de compartilhamento e freqüência de uso de droga injetável.

Após a entrevista, os indivíduos foram submetidos à coleta de sangue com separação do soro por centrifugação a $3000 \mathrm{rpm}$ e estocados a $-20^{\circ} \mathrm{C}$, para depois serem efetuadas as sorologias de: anti-HIV (1 ou 2), FTA-abs, anti-HBc, HBsAg, anti-HCV e anti-HTLV.

Estas sorologias serviram para se ter uma idéia de como o componente da transmissão parenteral poderia estar associado ao componente sexual nesta população.

O HIV e o vírus da hepatite B apresentam a mesma forma de infecção (sexual e parenteral); em contrapartida a hepatite $\mathrm{C}$ encontra, na forma parenteral, sua principal forma de infecção - nesta análise não estamos levando em conta a infectividade e a virulência dos vírus - estamos interessados em obter dados que fortaleçam nossa hipótese inicial - associação do HIV positivo com a transmissão parenteral - e não sermos surpreendidos com números discrepantes para nossa análise, isto é, uma alta taxa de hepatite B para uma baixa taxa de prevalência de 
hepatite $\mathrm{C}$ ( talvez muito próxima da população geral ). Isso seria a grosso modo, um indicativo de que o HIV positivo estaria mais intimamente ligado à infecção pela via sexual que pela parenteral, nesta população específica.

Para a sífilis serve a mesma analogia em relação ao componente sexual.

\section{Técnicas laboratoriais utilizadas}

Os soros foram testados pela técnica ELISA para HBsAg e anticorpos anti HCV (segunda geração), anti-HBcAg, anti-HIV (1 ou 2) Ag, anti-HTLV (1 ou 2) do laboratório ABBOTT.

O ELISA positivo para anticorpos anti-HIV foi confimado através do imunoblot da EMBRABIO LTD. Testes positivos para HTLV (1 ou 2) foram confirmados através do imunoblot com peptídeos sintéticos.

Para detecção do Treponema pallidum foi utilizado o FTA-abs da Diagnostics Pasteur (Syphilam $\left.{ }^{\circledR}\right)$.

\section{Análise matemática e estatística}

Os dados obtidos nas entrevistas e o resultado das sorologias foram armazenados num banco de dados padrão utilizando-se o software da Microsoft ${ }^{\circledR}$ FoxPro $^{\circledR}$ para MS DOS ${ }^{\circledR}$. Os textos redigidos utilizando-se o software da Microsoft ${ }^{\circledR}$ Word for Windows versão 2.0.

A análise univariada foi feita através do programa EpiInfo, versão 5.0 (1990[38]), e a análise multivariada (regressão logística) usando-se o pacote estatístico $\boldsymbol{B M D P}{ }^{\circledR}$ para o MS-DOS ${ }^{\circledR}(1990[46])$.

A análise matemática consistiu na estimativa da razão de Reprodutilibilidade basal, $\boldsymbol{R}_{\boldsymbol{0}}$, e da soroprevalência de equilíbrio $\boldsymbol{y}^{*}$ para o HIV nesta comunidade, através de um modelo original, desenvolvido para usuários de drogas injetáveis (1994[94]), a partir da idéia de modelos desenvolvidos anteriormente para infecções transmitidas por vetores (1952[86]). 


\section{Dedução de $\mathbf{R}_{0}$ para "agulhas"}

\section{Modelos de infecções transmitidas por vetor}

A quantificação da transmissão de agentes infecciosos através de vetores biológicos tem sido estudada por muitas décadas, desde os brilhantes trabalhos de

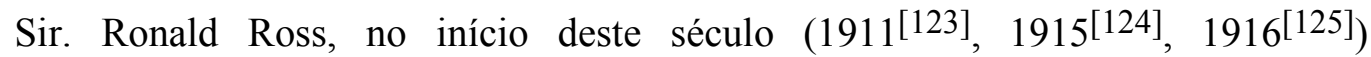
culminando com os desenvolvimentos de George Macdonald (1950[85], 1952[86], $\left.1953^{[87]}\right)$.

O conceito central relacionando a quantificação da transmissão é o chamado $\boldsymbol{R}_{\boldsymbol{0}}$, do parasita, que foi assim deduzido:

O caso primário poderia ser infectante por $1 / \boldsymbol{r}$ dias. Seja $\boldsymbol{m}$ a densidade de mosquitos em relação ao homem e $\boldsymbol{a}$ o número médio de picadas dadas por um mosquito por dia. Então, o número de mosquitos infectados pelo caso primário é $m a / r$.

Seja $\boldsymbol{p}$ a probabilidade de um mosquito sobreviver por um dia e $\boldsymbol{n}$ a duração em dias do período incubação extrínseco do parasita, pois, só a partir daí, o mosquito teria condições de infectar o homem.

Então, a expectativa de vida do mosquito, depois de $\boldsymbol{n}$ dias, é:

$$
\frac{p^{n}}{-\ln (p)}
$$

A equação (45) pode ser deduzida da seguinte maneira. 
Seja $\boldsymbol{p}$ a probabilidade da população de mosquitos sobreviver por 1 dia. Então a probabilidade de sobreviver $\boldsymbol{n}$ dias é $\boldsymbol{p}^{\boldsymbol{n}}$. A expectativa de vida, que é o valor esperado da duração de vida dos mosquitos, é dada por:

$$
\frac{\int_{0}^{\infty} t p^{t} d t}{\int_{0}^{\infty} p^{t} d t}=\frac{1}{-\ln (p)}
$$

No entanto, estamos interessados na expectativa de vida dos mosquitos após sobreviver o período de incubação extrínseco do parasita, expressa na equação (45).

Como cada mosquito pode picar o homem $\boldsymbol{a}$ vezes em cada dia de sua sobrevivência e sendo $\boldsymbol{b}$ a proporção destas picadas sejam infectantes, segue-se que o número total de infecções, a partir do caso primário, será:

$$
\mathrm{R}_{0}=\frac{\mathrm{ma}^{2} \mathrm{bp} \mathrm{p}^{\mathrm{n}}}{-\mathrm{r} \ln (\mathrm{p})}
$$

A taxa de esporozoíto, $\boldsymbol{S}$, definida por $1950^{[85]}$ como a proporção de mosquitos com esporozoítos nas suas glândulas salivares, é outro parâmetro crucial relacionado com a transmissão. Se a taxa de esporozoítos é vista como toda a vida do mosquito com esporozoítos em suas glândulas salivares, pode-se deduzi-la da seguinte maneira: seja $\boldsymbol{y}$ a proporção de hospedeiros infectados. O número médio de picadas infectadas por mosquito fêmea é ay. Então a probabilidade de picar pelo menos uma vez ao dia é $\left[1-\mathrm{e}^{-\mathrm{ay}}\right]$. A probabilidade disto não acontecer é [ $\left.\mathrm{e}^{-\mathrm{ay}}\right]$. A probabilidade de sobreviver um dia é $\boldsymbol{p}$, e a probabilidade de sobrevivência por um dia num estado não infectado é [pe ${ }^{- \text {ay }}$.

Logo, a expectativa de vida num estado não infectado é:

$$
\int_{0}^{\infty}\left(p e^{-a y}\right)^{t}=\frac{1}{a y-\ln (p)}
$$

A expectativa de vida na forma não infectada, depois de sobreviver $\mathbf{n}$ dias, é dada por:

$$
\frac{\mathrm{p}^{\mathrm{n}}}{\text { ay }-\ln (\mathrm{p})}
$$


logo, a taxa de esporozoítos, $\boldsymbol{S}$, pode ser expressa por:

$$
S=\frac{\left\{\frac{p^{n}}{-\ln (p)}-\frac{p^{n}}{a y-\ln (p)}\right\}}{\frac{1}{[-\ln (p)]}}
$$

a qual pode ser simplificada para:

$$
\mathrm{S}=\frac{\mathrm{p}^{\mathrm{n}} \text { ay }}{\mathrm{ay}-\ln (\mathrm{p})}
$$

A seguir, apresentamos uma dedução alternativa para a dedução da taxa de esporozoítos.

Seja $\mu$ a taxa de mortalidade do mosquito, e $\boldsymbol{P}(\mathbf{s}) \boldsymbol{d} \boldsymbol{s}$ a probabilidade de se encontrar um mosquito vivo com idade entre $\boldsymbol{s}$ e $\boldsymbol{s}+\boldsymbol{d} \boldsymbol{s}$. Então, a probabilidade de se encontrar um mosquito vivo com idade entre $(s+\Delta s)$ e $(s+\Delta s+d s)$ é:

$$
P(s+\Delta s)=P(s)(1-\mu \Delta s)
$$

ou

$$
\frac{d P(s)}{d s}=-\mu P(s)
$$

cuja solução é:

$$
P(s)=e^{-\mu s}
$$

Logo, o tempo médio de sobrevivência de mosquitos é $1 / \mu$.

A probabilidade de viver $\boldsymbol{n}$ unidades de tempo $(\boldsymbol{s}=\boldsymbol{n} \boldsymbol{T})$ é:

$$
P^{n}=e^{-\mu n T}=\left(e^{-\mu T}\right)^{n}
$$

assim, $\boldsymbol{p}$ na equação (45) é igual a $\mathrm{e}^{-\mu \mathrm{T}}$, sendo $\boldsymbol{T}$ considerado como igual a 1 dia. 
Calcula-se a probabilidade $\boldsymbol{P}^{\boldsymbol{0}}(\mathbf{s})$ de encontrarmos um mosquito não infectado, cuja idade esteja entre $\boldsymbol{s}$ e $\boldsymbol{s}+\boldsymbol{d} \boldsymbol{s}$. Se os mosquitos dão ay picadas infectadas por dia, a probabilidade de se encontrar um mosquito não infectado com idade entre $(\boldsymbol{s}+\Delta \boldsymbol{s})$ e $(\boldsymbol{s}+\Delta \boldsymbol{s}+\boldsymbol{d} \mathbf{s})$ é:

$$
P^{0}(s+\Delta s)=P^{0}(s)[1-(\mu+a y) \Delta s]
$$

$\mathrm{ou}$

$$
\frac{d P^{0}(s)}{d s}=-(\mu+a y) P^{0}(s)
$$

cuja solução é:

$$
P^{0}(s)=e^{-(\mu+a y) s}
$$

Consideremos a probabiidade $P^{i}\left(s_{0}, s\right) d s_{0} d s$ de encontrarmos um mosquito com idade entre $\boldsymbol{s}$ e $\boldsymbol{s}+\boldsymbol{d} \boldsymbol{s}$ e que tenha sido infectado pela primeira vez numa idade entre $\left[s_{(0)}\right]$ e $\left[s_{(0)}+d s_{(0)}\right]$ :

$$
P^{i}\left(s_{0}+s\right) d s_{0} d s=e^{-\left(a y s_{0}\right)} \text { ayds } s_{0} e^{-(\mu s)} d s
$$

A probabilidade de encontrarmos um mosquito infectado com idade entre $\boldsymbol{s}$ e $\boldsymbol{s}+\boldsymbol{d} \boldsymbol{s}$ com pelo menos $\boldsymbol{n}$ unidades de tempo, desde a primeira infecção é:

$$
\left[\int_{0}^{s-n T} p^{i}\left(s_{0}+s\right) d s_{0}\right] d s=\left[\int_{0}^{s-n T} e^{-a y s_{0}} a y d s_{0} e^{-\mu s}\right] d s
$$

cuja solução é:

$$
e^{\mu s}\left[1-e^{-a y(s-n T)}\right] d s
$$

A probabilidade de encontrarmos um mosquito infectado em qualquer idade, com pelo menos de $\boldsymbol{n}$ unidades de tempo desde a primeira infecção é:

$$
\int_{n T}^{\infty} e^{-\mu s}\left[1-e^{-a y(s-n T)}\right] d s=\frac{e^{-\mu n T} a y}{\mu(a y+\mu)}
$$

Finalmente, a proporção de mosquitos com esporozoítos em suas glândulas salivares, $\boldsymbol{S}$, é :

$$
\mathrm{S}=\frac{\mathrm{e}^{-\mu \mathrm{nT}} \text { ay }}{\mathrm{ay}+\mu}
$$


Considerando a notação de Macdonald, na qual $\mathrm{e}^{-\mu \mathrm{T}}=\mathrm{p}$ e $\mu=-\ln (p)$, e $\boldsymbol{T}=$ 1, obtemos a equação (51).

Outro parâmetro central, relacionado com a transmissão da malária, é a taxa de inoculação efetiva, $\boldsymbol{h}$, definida como o número de novas infecções que poderiam ocorrer em uma unidade de tempo (1916 $\left.{ }^{[125]}\right)$. Este parâmetro foi redefinido posteriormente $\left(1952^{[86]}\right)$ como:

$$
h=m a b S
$$

na qual substituindo-se $\boldsymbol{S}$ das equações (51) ou (63) temos:

$$
h=\frac{m a^{2} b y p^{n}}{a y-\ln (p)}
$$

A taxa de inoculação, $\boldsymbol{h}$, é o correspondente à "força de infecção", nos modelos dinâmicos. Este é o indicador mais usado para se medir a intensidade de transmissão para uma dada população e localidade, pois sua redução é o objetivo de qualquer estratégia de controle. Logo, esta estimativa é crucial num estudo epidemiológico.

De acordo com $1985^{[104]}$, há grande dificuldade para estimar-se $\boldsymbol{h}$ através dos dados entomológicos. Existe, no entanto, a alternativa de estimá-la através de dados de soroprevalência (1993[25], 1993[26]).

\section{AIDS em UDIs: quando a agulha pode ser um "vetor"}

Como mencionamos na introdução, seringas e agulhas podem tomar lugar de vetores biológicos, agindo como veículos de infecções, transmitidas parenteralmente. Assim, é natural estender-se os parâmetros definidos para malária por $1950^{[85]}, 1952^{[86]}, 1953^{[87]}$ e $1964^{[57]}$ para aqueles "vetores inanimados", os quais caracterizam novos cenários epidemiológicos. No entanto, algumas das hipóteses devem ser adaptadas face a esta nova aproximação.

Para o HIV, $\boldsymbol{R}_{\boldsymbol{0}}$ é essencialmente um produto de 3 fatores (1992[7]): a probabilidade média de uma pessoa infectada infectar o parceiro durante um relacionamento, o número médio de parceiros por unidade de tempo e a duração média da infectividade. Vejamos, agora, como a derivação de Macdonald pode ser aplicada entre os UDIs. 
Seja $1 / \alpha$ o período médio de tempo que uma agulha permanece circulando em uma população de UDIs. Porém, agulhas infectadas permanecem infectadas por um curto período de tempo $1 / \mu$, considerado dependente do tempo de coagulação do sangue residual no interior da agulha, o que inviabiliza sua reutilização.

Logo a "expectativa de vida" de uma agulha infectada é:

$$
\frac{1}{(\mu+\alpha)}
$$

A equação (66) é para a agulha equivalente à equação (45) para o mosquito.

Antes de continuar com a definição de $\boldsymbol{R}_{\boldsymbol{0}}$, vamos apontar algumas diferenças entre um vetor biológico como foi descrito por $1952^{[86]}$ e as agulhas:

- todo vetor que pica um hospedeiro infectado torna-se infectado (embora recentes publicações propõem que só uma fração destas picadas sejam infectantes para o vetor $\left(1991^{[6]}, 1992^{[48]}\right)$. Consideraremos que apenas uma fração, $\delta$, das agulhas que picam um indivíduo infectado, torna-se infectada;

- somente a fração $\boldsymbol{b}$ de vetores infectados é considerada como sendo infectante. Em contraste, nós consideramos que toda agulha infectada é infectante, embora por um período limitado de tempo $1 / \mu$.

- para vetores biológicos, o período infectante é toda a sua vida remanescente, depois de passado o período de incubação extrínseco. Em contraste, não existe período de incubação extrínseco do vírus na agulha. Isto implica na ausência de tempo entre a infecção e a infecciosidade para agulha. Logo, na agulha, o período infectante começa imediatamente após a picada e dura $1 /(\mu+\alpha)$ onde $1 / \alpha$ é a "expectativa de vida da agulha". Para as agulhas, temos:

$$
\begin{aligned}
& \boldsymbol{m}=\text { número médio de agulhas por UDIs, } \\
& \boldsymbol{a}=\text { número médio de picadas da agulha numa população de UDIs } \\
& \quad \text { por dia, logo: } \\
& \text { ma é, portanto, o número médio de picadas que um indíviduo } \\
& \quad \text { recebe por dia. } \\
& \begin{array}{l}
1 /(\mu+\alpha) \text { é a expectativa de vida da agulha na condição infectante; }
\end{array}
\end{aligned}
$$


$\boldsymbol{a} \delta(\mu+\alpha)$ é o número médio de picadas infectantes, por dia, durante o período infectante;

1/r é o período médio que o hospedeiro humano permanece infectante para as agulhas.

Consideraremos $1 / r$ como o período médio de tempo que um UDI compartilha "agulhas", numa comunidade específica.

Logo, a expressão de $\boldsymbol{R}_{\boldsymbol{0}}$ para agulhas é:

$$
R_{0}=\frac{m a^{2} \delta}{r(\mu+\alpha)}
$$

Agora deduziremos a expressão equivalente para esporozoíto taxa de inoculação, adaptada para "agulhas".

Se a probabilidade de encontrar uma agulha com "idade" entre $\boldsymbol{s}$ e $\boldsymbol{s}+\boldsymbol{d} \boldsymbol{s}$, seja $\boldsymbol{P}(\mathbf{s}) \boldsymbol{d} \boldsymbol{s}$, sendo $\alpha$ a taxa de "mortalidade" das "agulhas", a probabilidade de encontrar uma "agulha" com "idade" entre $s+d s$ e $s+d s+\Delta s$ é :

$$
P(s+\Delta s)=P(s)(1-\alpha \Delta s)
$$

onde

$$
P(s)=e^{-\alpha s}
$$

se $\boldsymbol{P}^{0}(\boldsymbol{s})$ for a probabilidade de encontrar uma "agulha" não infectada com "idade" entre $\boldsymbol{s}$ e $\boldsymbol{s}+\boldsymbol{d} \boldsymbol{s}$, e $\boldsymbol{P}^{\boldsymbol{i}}(\boldsymbol{s})$ a probabilidade de encontrar uma "agulha" infectada com a mesma "idade" (observar que e $\boldsymbol{P}^{\boldsymbol{0}}(\boldsymbol{s})+$ e $\left.\boldsymbol{P}^{i}(\boldsymbol{s})=\mathbf{1}\right)$, então:

$$
\begin{aligned}
& P^{0}(s+\Delta s) P(s+\Delta s)=P^{0}(s) P(s)[1-(\alpha+\delta a y) \Delta s] \\
& +\mu P^{i}(s) P(s) \Delta s \\
& P^{i}(s+\Delta s) P(s+\Delta s)=P^{0}(s) P(s) \delta a y \Delta s \\
& +P^{i}(s) P(s)[1-(\mu+\alpha) \Delta s]
\end{aligned}
$$

onde $\quad \alpha, \delta, \boldsymbol{a}, \boldsymbol{\mu}$ foram definidos anteriormente e $\boldsymbol{y}$ é a proporção de indivíduos infectados na população (considerou-se que a probabilidade de infecção é proporcional à probabilidade de encontrar-se um indivíduo infectado, isto é $y$ ).

A equação (70) significa que a probabilidade de encontrar uma "agulha"não infectada com idade entre $s+\Delta s$ é igual a probabilidade de encontrar 
uma "agulhas"não infectada com idade $s$ multiplicada pela probabilidade de não infectar-se no período entre $s$ e $s+\Delta s$ (primeiro termo da equação) mais a probabilidade de encontrar aquelas agulhas que estavam infectadas na idade $s$ e perderam sua infectividade, com taxa $\mu$, no mesmo período (segundo termo da equação).

A equação (71) significa que a probabilidade de encontrar uma "agulha" infectada com idade entre $s+\Delta s$ é igual a probabilidade de encontrar aquelas "agulha" não estavam infectadas com idade $\boldsymbol{s}$ e infectaram-se no período entre $\boldsymbol{s} \boldsymbol{e}$ $\boldsymbol{s}+\Delta \boldsymbol{s}$ (primeiro termo da equação) mais a probabilidade de encontrar aquelas agulhas que estavam infectadas na idade $s$ e ainda não perderam sua infectividade, ou "morreram", no mesmo período (segundo termo da equação).

Expandindo-se as equações (70 e 71) e, desconsiderando os termos de alta ordem e dividindo-se ambos por $\Delta s$, encontra-se o limite. Então temos os seguintes sistemas de equações diferenciais:

$$
\begin{aligned}
& \frac{d P^{0}(s)}{d s}=\delta a y P^{0}(s)+\mu P^{i}(s) \\
& \frac{d P^{i}(s)}{d s}=\delta a y P^{0}(s)-\mu P^{i}(s)
\end{aligned}
$$

onde a solução para Pi é:

$$
P^{i}(s)=\frac{\delta a y}{(\delta a y+\mu)}\left[1-e^{-(\delta a y+\mu) s}\right]
$$

Onde, a proporção de "agulhas" infectadas em uma população de "agulhas", $S_{A}$, é:

$$
S_{A}=\frac{\int_{0}^{\infty} P^{i}(t) P(t) d t}{\int_{0}^{\infty} P(t) d t}
$$

cuja solução é:

$$
S_{A}=\frac{\delta a y}{(\delta a y+\mu+\alpha)}
$$

A equação (76) aplicada nesta situação particular, corresponde à taxa de esporozoítos da equação (51) definida por Macdonald para malária. 
Observa-se que a taxa de esporozoítos, definida por Macdonald, é a proporção de mosquitos infectados. O correspondente conceito para agulhas está na equação (76) com $\boldsymbol{m}=\mathbf{0}$.

Esta quantificação representa a proporção de "agulhas" infectadas sem levar em consideração se continuarão infectadas ou não.

Substituindo-se $\boldsymbol{S}$ na equação (64) por $\boldsymbol{S}_{\boldsymbol{A}}$ da equação (76) obteremos a correspondente taxa de inoculação para as "agulhas":

$$
h=\frac{m a^{2} \delta y}{(\delta a y+\mu+\alpha)}
$$

da equação (67) conseguimos a espressão para o termo $m a^{2} \delta$ como função de $\boldsymbol{R}_{\boldsymbol{0}}$ :

$$
m a^{2} \delta y=R_{0} r(\mu+\alpha)
$$

substituindo-se a equação (78) na equação (77) obtemos a expressão para $\boldsymbol{h}$, como uma função de $\boldsymbol{R}_{\boldsymbol{0}}$ :

$$
h=\frac{R_{0} r(\mu+\alpha) y}{(\delta a y+\mu+\alpha)}
$$

Vejamos agora como a expressão de $\mathrm{R}_{0}$ para HIV pode ser deduzida de um sistema de equações diferenciais, que leva em conta a dinâmica das três populações: indivíduos suscetíveis à infecção, chamadas de $\boldsymbol{X}(\boldsymbol{t})$; indivíduos infectados pelo HIV, chamados $Y(t)$; e o número de agulhas infectadas, chamado de $\boldsymbol{P}^{\boldsymbol{i}}(\boldsymbol{s}, \boldsymbol{t})$. Deve-se notar que a última variável é função da idade da "agulha" $\boldsymbol{s}$ e o tempo $\boldsymbol{t}$. Então a equação diferencial para $\boldsymbol{P}^{\boldsymbol{i}}$ é:

$$
\frac{\partial P^{i}(s, t)}{\partial s}+\frac{\partial P^{i}(s, t)}{\partial t}=\delta a y(t)\left[N(s, t)-P^{i}(s, t)\right]-(\mu+\alpha) P^{i}(s, t)
$$

onde $N(s, t)$ é o número total de "agulhas" na população, $\delta, \mathbf{a}, \mu \mathrm{e} \alpha$, como acima, e $\boldsymbol{y}(\boldsymbol{t})$ é a proporção de indivíduos infectados na comunidade 
Integrando-se a equação (80), em relação à idade, $\boldsymbol{s}$, de zero a infinito, temos:

$$
\begin{aligned}
& \int_{0}^{\infty} P^{i}(s, t) d s=P^{i}(t) \\
& \mathrm{e} \\
& \int_{0}^{\infty} N(s, t) d s=N(t) \\
& \text { uma vez que } \\
& \int_{0}^{\infty} \frac{\partial P^{i}(s, t)}{\partial s} d s=0
\end{aligned}
$$

substituindo-se as equações (81), (82) e (83) na equação (80), e dividindose pelo número de hospedeiros humanos na população (considerado constante) temos:

$$
\frac{d P^{i}(t)}{d t}=\delta a y(t) m-[\delta a y(t)+(\mu+\alpha)] P^{i}(t)
$$

onde, $\boldsymbol{P}^{\boldsymbol{i}}(\boldsymbol{t})$ é a proporção de "agulhas" infectadas dividida pelo total da população e $\boldsymbol{m}$ é número total de "agulhas" (considerada constante) dividida pelo número da população humana.

Então, o sistema de equações, agora em proporções, é:

$$
\begin{aligned}
& \frac{d x(t)}{d t}=r y(t)-P^{i}(t) \operatorname{ax}(t) \\
& \frac{d y(t)}{d t}=P^{i}(t) a x(t)-r y(t) \\
& \frac{d P^{i}(t)}{d t}=\delta a y(t) m-[\delta a y(t)+(\mu+\alpha)] P^{i}(t)
\end{aligned}
$$

O termo $\boldsymbol{r y}(\boldsymbol{t})$ na equação (85) foi adicionado para manter a população total constante, não significando "taxa de recuperação" da infecção do HIV.

A solução trivial do sistema acima é $\mathbf{x}=\mathbf{1}, \mathbf{y}=\mathbf{p} \mathbf{i}=\mathbf{0}$, isto é, ausência de infecção. Aplicando o princípio da estabilidade linear (1988 $\left.{ }^{[128]}\right)$ podemos analisar a estabilidade do equilíbrio sobre a solução trivial e encontrar um limiar 
que torna este equilíbrio instável, isto é, o relacionamento entre os parâmetros que permitem a instalação da doença. Logo, linearizando o sistema de equações ( 84 a

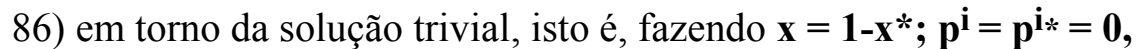

obtemos o seguinte sistema linear de equações:

$$
\begin{aligned}
& \frac{d x^{*}(t)}{d t}=P^{i^{*}}(t) a-r y^{*}(t) \\
& \frac{d y^{*}(t)}{d t}=P^{i^{*}}(t) a-r y^{*}(t) \\
& \frac{d P^{i^{*}}(t)}{d t}=\delta a m y^{*}(t)-(\mu+\alpha) P^{i^{*}}(t)
\end{aligned}
$$

O sistema linear de equações (87 a 89) tem a seguinte Matriz Jacobiana:

$$
A=\left[a_{i, j}\right]_{p e t^{\prime}} \quad \mathrm{i}, \mathrm{j}=1, \ldots 3
$$

onde pet significa ponto de equilíbrio trivial. Logo, temos que:

$$
[A-\lambda I]=\left(\begin{array}{ccc}
-\lambda & -r & a \\
0 & -(r+\lambda) & a \\
0 & \delta a m & -(\mu+\alpha+\lambda)
\end{array}\right)
$$

onde $\lambda$ são os autovalores da matriz Jacobiana. De acordo com o Teorema de Lyapunov (1981[62]), o sistema (87 a 89) tem o equilíbrio estável se $\hat{\boldsymbol{A} e}(\lambda)<\boldsymbol{0}$ para todos os autovalores.

O limiar para a solução trivial é:

$$
\delta a^{2} m=r(\mu+\alpha)
$$

Logo, se para a equação de $\boldsymbol{R}_{\boldsymbol{0}}$ tivermos a condição:

$$
\frac{\delta a^{2} m}{r(\mu+\alpha)}>1
$$

a estabilidade da solução trivial é "quebrada" e a doença pode aparecer. A equação (93) é exatamente a definição de $\boldsymbol{R}_{\boldsymbol{0}}$ para as "agulhas". A dedução acima de $\boldsymbol{R}_{\boldsymbol{0}}$ será usada no próximo item. 


\section{Heterogeneidades}

Vejamos como é possível modificar o modelo da seção anterior, de maneira a considerar as heterogeneidades que determinam o risco de adquirir a infecção pelo HIV com o uso de drogas injetáveis.

\section{Heterogeneidade na fonte de infecção}

A primeira heterogeneidade a ser considerada refere-se ao próprio cálculo da chance da agulha infectar-se, após "picar" um indivíduo infectado, $\delta$.

Consideraremos que a chance de uma agulha infectar-se, $\delta$, após "picar" um indivíduo infectado, varia com a distribuição da concentração de HIV circulante na população hospedeira.

Seja o inóculo infectante para a agulha, $\boldsymbol{i}$ Unidades Infectantes para Cultura de Tecido (UITC) definido experimentalmente para o HIV (1989[68]). Então a probabilidade, $\boldsymbol{P}(\boldsymbol{i})$, de uma agulha com o volume residual de $\boldsymbol{v} \mathrm{ml}$ de sangue, depois de picar um indivíduo infectado, tenha $i$ UITC é:

$$
P(i)=\sum_{n=0}^{\infty} \frac{e^{-n v}(n v)^{i}}{i !} P(n \mid \varphi)
$$

onde $\boldsymbol{n}$ corresponde à concentração de HIV (em UITC) numa amostra aleatória individual de uma população infectada com média $\varphi$ UITC por ml.

Considerando que uma UITC é suficiente para infectar a agulha, então a probabilidade de existir pelo menos um inóculo infectante, $\delta$, é:

$$
\delta=P(i \geq 1)=[1-P(0)]
$$

Para ilustrar a análise acima, consideremos duas situações possíveis:

- o inóculo infectante está homogeneamente distribuído na população infectada, então:

$$
P(n \mid \varphi)=\left\{\begin{array}{lll}
1 & \text { if } & n=\varphi \\
0 & \text { if } & n \neq \varphi
\end{array}\right.
$$

onde, $\boldsymbol{P}(\boldsymbol{i})$ é então reduzido à distribuição de Poisson:

$$
P(i)=\frac{e^{-\varphi v}(\varphi v)^{i}}{i !}
$$


logo:

$\delta=1-\mathrm{e}^{-\varphi \mathrm{v}}$

- o inóculo infectante está heterogeneamente distribuído na população infectante, então:

$$
\delta=P(i \geq 1)=1-\sum_{n=0}^{\infty} e^{-n v} P(n \mid \varphi)
$$

Consideraremos que a distribuição de inóculos infectantes entre a população infectada, $\boldsymbol{P}_{(\boldsymbol{n} \mid \varphi)}$, é uma distribuição binomial negativa, com parâmetro $\boldsymbol{k}$ (1964[11]) como já descrito previamente em vários estudos epidemiológicos (1982[1]) com a forma:

$$
P(n \mid \varphi)=P(n \mid \varphi, k)=(1-\varepsilon)^{k} \frac{\Gamma(k+n)}{\Gamma(k)} \frac{\varepsilon}{n}^{n}
$$

onde:

$$
\varepsilon=\frac{\varphi}{\varphi+\mathrm{k}}
$$

Considerando que a função da geratriz de probabilidades, g, para a distribuição binomial negativa é dada por (1964[11]):

$$
g(z)=(1-\varepsilon)^{k}(1-\varepsilon z)^{-k}
$$

finalmente obtemos:

$$
\delta=P(i \geq 1)=1-(1-\varepsilon)^{k}\left(1-\varepsilon e^{-v}\right)^{-k}
$$

onde $v$, como mencionamos acima, é o volume residual de sangue na agulha e $\boldsymbol{k}$, que é obtido da distribuição do inóculo na população, é definido como:

$$
k=\frac{\frac{\varphi^{2}}{\sigma^{2}}}{1-\left[\frac{\varphi^{2}}{\sigma^{2}}\right]}
$$

onde $\varphi$ é a média e $\sigma^{2}$ é a variância da distribuição do inóculo na população. 


\section{Heterogeneidade na taxa de exposição}

Iremos considerar uma importante diferença entre o comportamento de um vetor biológico e o vetor inanimado, a "agulha". É razoável considerar-se que a taxa de picadas é uma constante para o mosquito, uma vez que não existem razões para que um mosquito da mesma espécie pique mais que outro. Além disso, como a picada é distribuída aleatóriamente e é um evento relativamente raro para a população de mosquitos, está claro que o valor médio da taxa de picadas, $\boldsymbol{a}$, deve ser suficiente.

Por outro lado, a "agulha" é necessariamente dirigida pelo usuário de droga. Isto implica numa variação grosseira da "taxa de picadas". Soma-se a isto o fato de que os indivíduos variam bastante em seus hábitos em relação "às agulhas". Também é razoável supor que diferentes comunidades de UDIs têm hábitos diferentes. Consideraremos, para o propósito deste item, somente comunidades isoladas, definindo como um grupo de UDIs, aquele onde todos relacionam-se com todos, e ninguém fica fora desta comunidade. Iremos relaxar esta hipótese na interação entre comunidades, tratado à frente.

Com o objetivo de ilustrar as considerações, acima vamos considerar, por simplificação, a situação na qual há somente dois grupos de UDIs, classificados pela sua taxa de uso e hábitos de compartilhamento de "agulhas".

Seja $\boldsymbol{x}_{\boldsymbol{1}}(\boldsymbol{t})$ a fração de UDIs não infectados no tempo $\boldsymbol{t}$ da classe 1 , que utiliza droga injetável $\boldsymbol{m a} \boldsymbol{a}_{\boldsymbol{1}}$ vezes por unidade de tempo e compartilha "agulhas" com probabilidade $\boldsymbol{p}_{1}$. Da mesma forma, seja $\boldsymbol{x}_{2}(\boldsymbol{t})$ a fração de UDIs não infectados no tempo $\boldsymbol{t}$ da classe 2 , que utiliza droga injetável $\boldsymbol{m} \boldsymbol{a}_{2}$ vezes por unidade de tempo e compartilha "agulhas" com probabilidade $\boldsymbol{p}_{2}$.

Sejam $\boldsymbol{y}_{1}$ e $\boldsymbol{y}_{2}(\boldsymbol{t})$ as proporções correspondentes aos UDIs infectados. Consideramos que $\boldsymbol{x}_{1}(\boldsymbol{0})$ e $\boldsymbol{x}_{2}(\boldsymbol{0})$ são constantes, isto é, o aporte de indivíduos com diferente hábitos é tal que estas frações permanecem constantes. As equações (84 a 86) são agora escritas como:

$$
\begin{aligned}
& \frac{\mathrm{dx}_{1}}{\mathrm{dt}}=\mathrm{ry}_{1}-\mathrm{P}^{\mathrm{i}} \mathrm{a}_{1} \mathrm{P}_{1} \mathrm{x}_{1} \\
& \frac{\mathrm{dx}_{2}}{\mathrm{dt}}=\mathrm{ry}_{2}-\mathrm{P}^{\mathrm{i}} \mathrm{a}_{2} \mathrm{P}_{2} \mathrm{x}_{2} \\
& \frac{\mathrm{dy}}{\mathrm{dt}}=\mathrm{P}^{\mathrm{i}} \mathrm{a}_{1} \mathrm{x}_{1}-\mathrm{ry}_{1}
\end{aligned}
$$




$$
\begin{aligned}
& \frac{\mathrm{dy}_{2}}{\mathrm{dt}}=\mathrm{P}^{\mathrm{i}} \mathrm{a}_{2} \mathrm{x}_{2}-\mathrm{ry}_{2} \\
& \frac{d P^{i}}{d t}=\delta\left(m-P^{i}\right)\left(a_{1} y_{1}+a_{2} y_{2}\right)-(\mu+\alpha) P^{i}
\end{aligned}
$$

A solução trivial para o sistema acima é $x_{1}=x_{1}(0) ; x_{2}=x_{2}(0) ; y_{1}=y_{2}=0$ e $\boldsymbol{P} \boldsymbol{i}=\boldsymbol{0}$. Linearizando o sistema de equações (105 a 109) em torno da solução trivial, isto é, fazendo $\boldsymbol{x}_{1}(\boldsymbol{t})=\boldsymbol{x}_{1}(\boldsymbol{0})-\boldsymbol{x}_{1} *(\boldsymbol{t})$, etc., obtemos:

$$
\begin{aligned}
& \frac{d y_{1}^{*}}{d t}=P^{i^{*}} a_{1} p_{1} x_{1}(0)-r y_{1}^{*} \\
& \frac{d y_{2}^{*}}{d t}=P^{i^{*}} a_{2} p_{2} x_{2}(0)-r y_{2}^{*} \\
& \frac{d P^{i^{*}}}{d t}=\delta m\left(a_{1} y_{1}^{*}+a_{2} y_{2}^{*}\right)-(\mu+\alpha) P^{i^{*}}
\end{aligned}
$$

A solução trivial é estável (instável) de acordo com a condição:

$$
R_{0}=\frac{\delta m\left(a^{2}{ }_{1} P_{1} x_{1}(0)+a^{2}{ }_{2} P_{2} x_{2}(0)\right)}{r(\mu+\alpha)}
$$

ser menor (maior) que 1.

Comparando a expressão para $\boldsymbol{R}_{\boldsymbol{0}}$ dada pela equação (93) e a acima, a taxa média diária de picadas $\boldsymbol{a}^{2}$ é substituída por uma média quantitativa apropriada $\left\lfloor a_{1}^{2} P_{1} x_{1}(0)+a^{2}{ }_{2} P_{2} x_{2}(0)\right\rfloor$.

No caso geral de $\boldsymbol{n}$ classes, $\boldsymbol{R}_{\boldsymbol{0}}$ torna-se:

$$
R_{0}=\frac{\delta m \sum_{j=1}^{n} \sum_{i=1}^{1}\left[a^{2}{ }_{i} p_{j} x_{i j}(0)\right]}{r(\mu+\alpha)}
$$

onde $\mathrm{x}_{\boldsymbol{i} \boldsymbol{J}}$ é a fração de UDIs não infectados no tempo zero, os quais usam "agulhas" $\boldsymbol{a}_{\boldsymbol{i}}$ vezes por unidade de tempo, e compartilham "agulhas" com a probabilidade $\boldsymbol{p}_{\boldsymbol{J}}$.

Calcularemos, a seguir, a proporção $\boldsymbol{y}_{\boldsymbol{J}}$ (prevalência) de indivíduos infectados em cada classe, no equilíbrio, e a proporção de "agulhas" infectadas na população. Para simplificar a notação, consideraremos os produtos como $\boldsymbol{a}_{\boldsymbol{i}} \boldsymbol{p}_{\boldsymbol{i}} \mathrm{e}$ $\boldsymbol{a}_{\boldsymbol{J}} \boldsymbol{p}_{\boldsymbol{J}}$ como diferentes, mesmo que $\boldsymbol{a}_{\boldsymbol{i}}=\boldsymbol{a}_{\boldsymbol{J}}$ e $\boldsymbol{p}_{\boldsymbol{i}}=\boldsymbol{p}_{\boldsymbol{J}}$. Isto significa que cada classe é caracterizada como $\boldsymbol{a}_{\boldsymbol{i}}$ e $\boldsymbol{p}_{\boldsymbol{i}}$. 
A proporção de equilíbrio de "agulhas" infectadas é dada por uma equação algébrica de grau $\boldsymbol{n}$ (anexo I)

A proporção de equilíbrio das "agulhas" infectadas é dada na equação (anexo $I$ ) com $\boldsymbol{\mu}=\mathbf{0}$. Este é o parâmetro equivalente à taxa de esporozoítos dada por $1950^{[85]}$.

A proporção de indivíduos infectados na classe $\boldsymbol{k}$ pode ser calculada a partir de $\boldsymbol{P} \boldsymbol{i}$, como:

$$
y_{k}=\frac{P^{i} a_{k} p_{k} x_{k}(0)}{a_{k} p_{k} P^{i}-r}
$$

e a prevalência média é dada por:

$$
y=\frac{1}{n} \sum_{k=1}^{n} \frac{P^{i} a_{k} p_{k} x_{k}(0)}{a_{k} p_{k} P^{i}-r}
$$

[116]

\section{Interação entre comunidades}

Nos subitens prévios consideramos comunidades de UDIs isoladas. Neste ítem direcionamos o problema para as interações entre as comunidades. Para simplificar, consideramos somente 2 comunidades, cada uma contendo 2 grupos de UDIs. Denotaremos as 2 comunidades com superescrito I e II e os membros das comunidades com subescrito 1 e 2 .

Denotando $\beta_{i}^{I}$ e $\beta_{i}^{I I}$ como a proporção do uso de agulhas compartilhadas pelos indivíduos dentro da própria comunidade, as equações (107 a 109) são substituídas por:

$$
\begin{aligned}
& \frac{d y_{j}^{I}}{d t}=\left(\beta_{j}^{I} P^{i I}+\left(1-\beta_{j}^{I}\right) P^{i I I}\right) P_{j}^{I} a_{j}^{I} x_{j}^{I}-r y_{j}^{I} \quad \mathrm{j}=1,2 \\
& \frac{d y_{j}^{I I}}{d t}=\left(\beta_{j}^{I I} P^{i I I}+\left(1-\beta_{j}^{I I}\right) P^{i I I}\right) P_{j}^{I I} a_{j}^{I I} x_{j}^{I I}-r y_{j}^{I I} \mathrm{j}=1,2 \\
& \frac{d y_{j}^{I}}{d t}=\delta\left(m^{i}-P^{i I}\right)\left(\beta_{1}^{I} a_{1}^{I} y_{1}^{I}+\beta_{2}^{I} a_{2}^{I} y_{2}^{I}\right)+ \\
& \left.\delta\left(m^{I}-P^{i I}\right)\left(1-\beta_{1}^{I I}\right) a_{1}^{I I} q_{1}^{I I} y_{1}^{I I}\right)+ \\
& {\left[\left(1-\beta_{2}^{I I}\right) a_{2}^{I I} q_{2}^{I I} y_{2}^{I I}\right]-(\mu+\alpha) P^{i I}}
\end{aligned}
$$




$$
\begin{aligned}
& \frac{d y_{j}^{I I}}{d t}=\delta\left(m^{I I}-P^{i I I}\right)\left(\beta_{1}^{I I} a_{1}^{I I} y_{1}^{I I}+\beta_{2}^{I I} a_{2}^{I I} y_{2}^{I I}\right)+\delta\left(m^{I I}-P^{i I I}\right)\left(1-\beta_{1}^{I}\right) a_{1}^{I} q_{1}^{I} y_{1}^{I}+ \\
& \left.\left(1-\beta_{2}^{I}\right) a_{2}^{I} q_{2}^{I} y_{2}^{I}\right)-(\mu+\alpha) P^{i I I}
\end{aligned}
$$

onde $\boldsymbol{q}_{\boldsymbol{i}}^{\boldsymbol{I}}$ e $\boldsymbol{q}_{\boldsymbol{i}}^{\boldsymbol{I I}}(\mathrm{i}=1,2)$ são as proporções de indivíduos que compartilham seringas com indivíduos da outra comunidade.

Agora, se as comunidades são isoladas, isto é, $\boldsymbol{\beta}_{\boldsymbol{j}}^{\boldsymbol{I}}=\boldsymbol{\beta}_{\boldsymbol{j}}^{\boldsymbol{I I}}=1(\mathrm{j}=1,2)$ e $\boldsymbol{q}_{\boldsymbol{i}}^{\boldsymbol{I}}=0=\boldsymbol{q}_{\boldsymbol{i}}^{\boldsymbol{I I}}(\mathrm{i}=1,2)$, o sistema (117 a 120) se desacopla e obtemos os mesmos resultados como antes, com dois distintos $\boldsymbol{R}_{\boldsymbol{O}}$ dados por:

$$
R_{0}^{v}=\frac{\delta m^{v}\left[\left(a_{1}^{v}\right)^{2} P_{1}^{v} x_{1}^{v}(0)+\left(a_{2}^{v}\right)^{2} p_{2}^{v} x_{2}^{v}(0)\right]}{r(\mu+\alpha)}, v=1,2
$$

Em geral, não esperamos comunidades isoladas para UDIs. No entanto, temos de estudar sobre quais circunstâncias faz sentido considerar toda a comunidade composta por partes distintas, cada uma descrevendo diferentes comportamentos sociais de seus componentes. Aplicando o princípio da estabilidade linear para as equações (117 a 120) podemos analisar a estabilidade do equilíbrio em torno da solução trivial e verificamos como a presença da comunidade 1 afeta o limiar da comunidade 2 e vice-versa. $\mathrm{O}$ resultado pode ser sumarizado como segue, porém primeiro definiremos 5 funções auxiliares (anexo II).

Os autovalores deste sistema são obtidos obedecendo à equação:

$$
\lambda^{4}+\mathrm{a}_{3} \lambda^{3}+\mathrm{a}_{2} \lambda^{2}+\mathrm{a}_{1} \lambda+\mathrm{a}_{0}=0
$$

onde:

$$
\begin{aligned}
& a_{3}=2(r+\mu+\alpha) \\
& a_{2}=(r+\mu+\alpha)^{2}+\left[r(\mu+\alpha)-G_{1}\right]+\left[r(\mu+\alpha)-G_{2}\right] \\
& a_{1}=(r+\mu+\alpha)\left\{\left[r(\mu+\alpha)-G_{1}\right]+\left[r(\mu+\alpha)-G_{2}\right]\right\} \\
& a_{0}=\left[r(\mu+\alpha)-G_{1}\right]\left[r(\mu+\alpha)-G_{2}\right]+\left[G_{3}-G_{4}\right]
\end{aligned}
$$

Se $\boldsymbol{G}_{3} \cong 0$ e $\boldsymbol{G}_{4} \cong 0$, então as duas comunidades interagem fracamente, isto é, o número de indivíduos de uma comunidade raramente compartilham "agulhas" com indivíduos pertencentes a outra comunidade. 
O limiar para a infecção prevalecer é aproximadamente:

$$
R_{0}^{I} \cong \frac{G_{1}}{r(\mu+\alpha)}
$$

e

$$
R_{0}^{I I} \cong \frac{G_{2}}{r(\mu+\alpha)}
$$

Se $\boldsymbol{R}_{\boldsymbol{0}} \boldsymbol{I}_{>}$, a infecção prevalece na comunidade 1 independente da comunidade 2 e se $\boldsymbol{R}_{\boldsymbol{0}}{ }^{\boldsymbol{I}}>\boldsymbol{1}$ a infecção prevalece na comunidade 2 independente da comunidade 1; quando ambos $\boldsymbol{R}_{\boldsymbol{0}}$ são maiores que 1 , a infecção prevalece em ambas as comunidades ao mesmo tempo.

Quando a interação entre as duas comunidades é forte, então o critério de

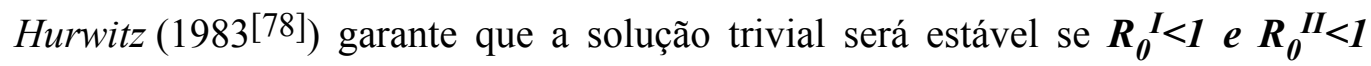
como acima, mas uma condição anterior pode ser satisfeita, a saber:

$$
\left[\mathrm{G}_{1}+\mathrm{G}_{2}\right]>2\left[\mathrm{G}_{3}+\mathrm{G}_{5}\right]^{1 / 2}
$$

No entanto, como foi discutido acima, quando a interação entre as duas comunidades é forte, os grupos devem ser redefinidos sempre que possível. 


\section{Características da amostra}

D

os 197 indivíduos recrutados na amostra, todos concordaram em responder ao questionário e não se recusaram a colher material para sorologia. Foi obtido desta amostra, quantidade de soro suficiente para todas as sorologias estudadas. Um número de soros eqüivalente, foram obtidos do banco de sangue central da cidade de Santos, pareados por idade e sexo.

É importante ressaltar que o questionário não foi aplicado aos indivíduos da amostra do banco de sangue, porém, estes foram triados, com a intenção de se eliminar os indivíduos com história de risco para doenças de transmissão parenteral e sexual.

A amostra de UDIs é composta por $60 \%$ homens e $40 \%$ mulheres, com idade variando entre 13 e 54 anos, com média de 28,3 anos ( $\mathrm{sd}=7,4$ anos).

Uma porcentagem de $77 \%$ dos UDIs relataram pelo menos uma prisão anterior e que passaram pelo menos uma noite na prisão. A média de vezes de detenção foi de 5,3 vezes e a de tempo de prisão foi de 17,7 meses. Foi reportado por $8,6 \%$ dos UDIs o uso de droga injetável na prisão.

O acesso a informações acerca de medidas de prevenção contra a AIDS no último ano foi referido por $77 \%$ destes indivíduos.

Com relação ao local de residência permanente, $81 \%$ relataram serem residentes de Santos. O tempo médio de residência na cidade de Santos foi de 13,5 meses.

O tempo médio de educação foi de 5,7 anos ( $\mathrm{sd}=3,5$ anos) e a média de idade em que estes indivíduos interromperam a educação formal foi de 14,7 anos ( $\mathrm{sd}=5,7$ anos). 
Somente $18 \%$ da amostra tinham qualquer tipo de emprego regular; a fonte de renda de $39 \%$ era proveniente de prática ilegal, além de serem UDIs.

A porcentagem de de solteiros da amostra era de $58 \%$, sendo que $4 \%$ eram casados(as), 4\%, viúvos(as), 10\%, divorciados(as) e 23\% tinham parceiro sexual regular.

\section{Padrões de injeção de drogas}

A média de idade do primeiro uso de droga injetável nesta amostra foi de 18,7 anos. Aproximadamente metade deles referiu ter usado droga injetável nos últimos 2 meses. A droga mais utilizada neste grupo foi a cocaína, usada por $95 \%$ dos indivíduos sendo que, $99 \%$ como uso injetável. A maconha foi usada por $74 \%$, e o crack, proveniente da cocaína, por $10 \%$ dos indivíduos. Com respeito a outras drogas, $5 \%$ relataram o uso de heroína, dos quais $81 \%$ fizeram o seu uso injetável; $8 \%$ usaram anfetaminas, sendo $40 \%$ injetável; $7 \%$ usaram barbitúricos. Ninguém se referiu ao uso de heroína e cocaína combinadas. Outras drogas foram relatadas com freqüências muito baixas.

O uso de drogas injetáveis apresentou uma variação muito grande neste grupo, e por não sabermos se esta variação é ou não simétrica, preferimos considerar a mediana como o valor mais representativo deste conjunto. A mediana de uso de droga injetável, em um mês típico, nos últimos 6 meses, foi de 16,5 dias por mês, variando de 1 a 31 dias/mês. A intensidade de uso de drogas apresenta uma mediana de 7,4 vezes ao dia, variando de 1 a 50 vezes/dia. O compartilhamento de "agulhas" foi relatado por 56\% dos indivíduos, dos quais $83 \%$ relataram terem recebidos de amigos, $34 \%$ de outro UDI, no momento do compartilhamento da droga, $24 \%$ de parceiros sexuais, $3 \%$ de traficantes. $\mathrm{O}$ número médio de indivíduos, compartilhando "agulhas", foi de 3,5 indivíduos ( $s d=2,0$ indivíduos). Não houve diferença significativa entre os gêneros para essas variáveis. No entanto, esta diferença é observada, quando consideramos somente a porcentagem de UDIs que fazem uso da droga injetável todo dia, $31 \%$ da amostra. Onde observou-se uma composição de $25 \%$ dos homens e $42 \%$ das mulheres $(p=0,0108)$.

Dos 111 UDIs que citaram o compartilhamento de "agulhas", 62\% afirmaram limpá-las sempre, enquanto $8 \%$ nunca o faziam. Dos que sempre 
limpavam, somente $17 \%$ deles usaram produtos com real poder de limpeza (aqui foi considerado: água fervente, álcool e água sanitária). Não houve diferença significativa destas variáveis para os dois gêneros.

Foi relatado por $68 \%$ dos indivíduos, que a razão mais freqüente do compartilhamento, foi não possuir o equipamento para injeção no momento do uso; o medo de carregar estes equipamentos com receio de coação policial foi relatado por $12 \%$, dificuldade de obtenção por $8,5 \%$ e o alto preço $7,5 \%$. Somente $23 \%$ referiram a prática do compartilhamento por ser agradável. Não houve diferença significativa para estas variáveis, em relação a gênero. É importante ressaltar que $12 \%$ referiram compartilhamento por pressão do grupo, sendo que, neste caso, $18 \%$ eram homens e $3 \%$, mulheres $(\boldsymbol{p}=\mathbf{0 , 0 8 0 9})$.

A farmácia foi o local onde $97 \%$ dos UDIs, reportaram terem adquirido agulhas e seringas novas.

Somente $23 \%$ da amostra relataram ter algum tipo de tratamento relativo ao uso abusivo de drogas. Isto reflete a escasses de serviços públicos de saúde que contemplem este tipo de abordagem, em relação ao UDI.

\section{Comportamento sexual}

Entre os UDIs, $83 \%$ relataram terem tido contato sexual nos últimos 6 meses. Destes, $17 \%$ disseram terem tido relação anal. Um número maior de mulheres que de homens tiveram mais de um contato sexual por semana sendo $95 \%$ das mulheres e $65 \%$ dos homens $(\boldsymbol{p}<\mathbf{0 , 0 0 0 1})$. Com relação à prostituição foi observado uma porcentagem de $53 \%$ entre as mulheres e $7 \%$ entre os homens $(\boldsymbol{p}<\mathbf{0 , 0 0 0 1})$.

Foram avaliados vários tipos de relacionamentos, com diversos tipos de parceiros sexuais, assim definidos:

- parceiro sexual regular - aquele com o qual o indivíduo possuia um relacionamento mais duradouro;

- parceiro sexual ocasional-aquele com o qual o indivíduo tinha um relacionamento sexual ocasional, diferindo de clientes, por não envolver pagamento; 
- cliente - aquele com o qual o indivíduo tinha relacionamento sexual, e que envolvia alguma forma de pagamento.

O número médio de parceiros sexuais, relatado nos últimos 6 meses, foi de $1,5(\mathrm{sd}=3,49)$ e $10,6(\mathrm{sd}=23,76)$ para parceiros sexuais regulares e ocasionais respectivamente. Não houve diferença significante, com relação ao sexo, para esta variável. Aqueles que relataram prostituição apresentaram um número médio de clientes de 36 por mês nos últimos 6 meses, sendo que entre os homens a média foi de 14 clientes e entre as mulheres de 41 clientes por mês $(\boldsymbol{p}=\mathbf{0 , 0 0 2})$.

Com relação ao uso de preservativos, a amostra apresentou um comportamento bastante irregular. Aparece mais prevalente quando o contato sexual ocorre com parceiros ocasionais. Da amostra, 69\% relataram que nunca tinha usado "condoms" com parceiros regulares, enquanto $46 \%$ nunca haviam usado com parceiros ocasionais $(\boldsymbol{p}=\mathbf{0 , 0 0 4 2})$. Por outro lado, não houve diferença significativa quando se considerou o uso de preservativo em toda relação onde, $16 \%$ faziam este uso com parceiro sexual regular enquanto que $22 \%$ com o ocasional $(\boldsymbol{p}=\mathbf{0 , 3 1})$. Quando se discrimina o uso de preservativos por sexo, os homens são mais resistentes ao seu uso: $77 \%$ deles nunca usam condom com parceiro regular quando comparado com 58\% das mulheres $(\boldsymbol{p}=\mathbf{0 , 0 7 5})$; $58 \%$ dos homens e $22 \%$ das mulheres referiram nunca ter usado condom com parceiro ocasional $(\boldsymbol{p}=\mathbf{0 , 0 0 4 8})$.

Finalmente, 29\% dos homens relataram terem tido sexo com outro homem nos últimos 5 anos.

\section{Prevalência sorológica}

A soroprevalência para HIV resultou positiva para $62 \%$ da amostra, sem apresentar, no entanto, diferença significativa, entre os homens com $59 \%$ e as mulheres com $67 \%(\boldsymbol{p}=\mathbf{0 , 2 2})$. Os resultados dos testes sorológicos para HIV, hepatite B e C, sífilis e HTLV (1 ou 2) estão resumidos na figura 7, e tabelas 6 a 8.

Como não houve diferença significativa na associação do HTLV 1 ou 2 com os fatores de risco estudados, os dados correspondentes a estas viroses serão apresentados, indiscriminadamente, como HTLV (1 ou 2). 
A figura 7 ilustra as diferenças encontradas entre UDIs e doadores de sangue para prevalência de HIV, sífilis, hepatites B e C, e HTLV (1 ou 2) respectivamente.

Figura 7. Soroprevalência em usuários de drogas injetáveis e doadores de sangue, pareados por idade e sexo, na cidade de Santos - 19911993.

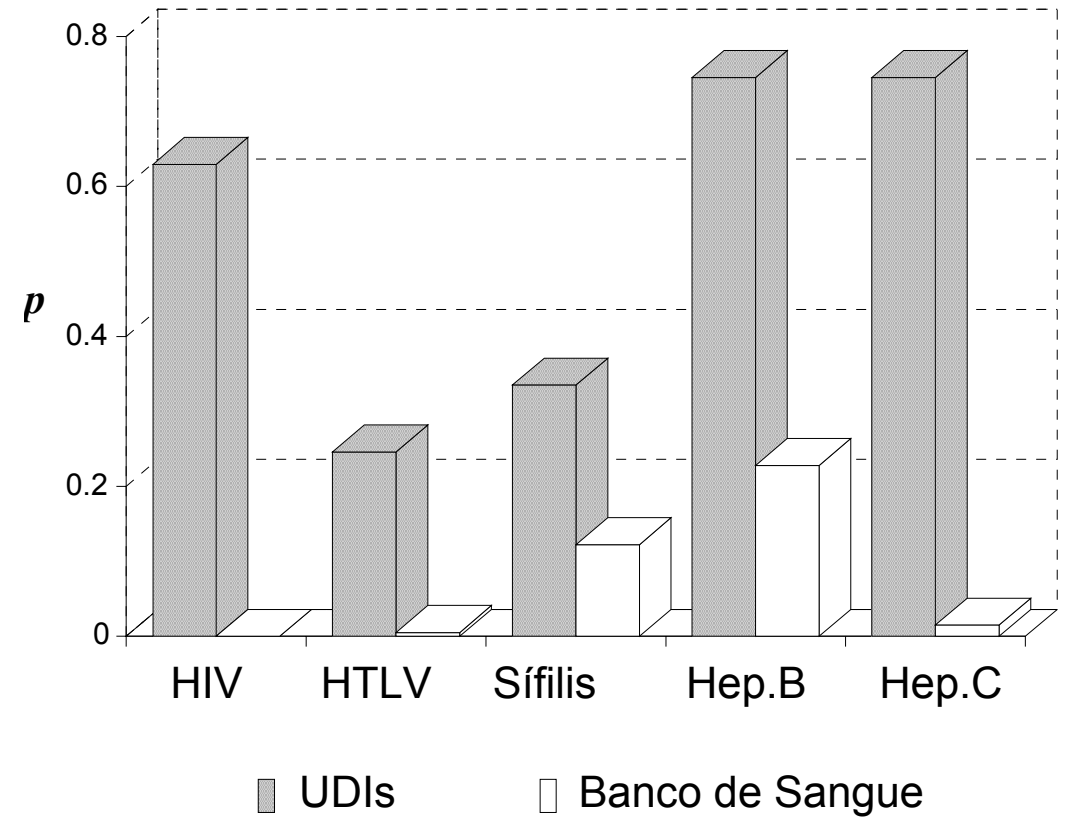

A tabela 6 mostra os resultados, comparando UDIs e doadores de sangue, como descritos nos estudos sorológicos. Estes dados, mostram que há um aumento no risco para as infecções de transmissão parenteral e sexual, quando comparado com doadores de sangue pareados por idade e sexo, na cidade de Santos. O risco parenteral apresenta-se acentuadamente como o mais importante. 
Tabela 6. Análise univariada comparando soroprevalência entre usuários de drogas injetáveis pareados com doadores de sangue, na cidade de Santos, 1991-1993.

\begin{tabular}{lrrrrr}
\hline & HIV & HTLV(1ou2) & Shyphilis & HBV & HCV \\
\hline UDIs & 0,62 & 0,25 & 0,34 & 0,75 & 0,75 \\
doadores & 0,00 & 0,01 & 0,12 & 0,23 & 0,02 \\
OR & - & 50 & 3,57 & 10,0 & 100 \\
IC (95\%) & - & $9,09-150$ & $2,08-6,25$ & $5,88-16,67$ & $50-200$ \\
$\chi^{2}$ & - & 52,07 & 25,4 & 103,99 & 222,22 \\
$\mathrm{p}$ & - & $<0,00001$ & $<0,00001$ & $<0,00001$ & $<0,00001$ \\
\hline
\end{tabular}

A tabela 7 mostra os resultados da sorologia, comparando homens e mulheres na amostra de UDIs, onde é observada uma diferença significativa, a nível de 5\%, na soroprevalência de sífilis e hepatite B. Esta diferença pode ser atribuída à maior atividade sexual entre as mulheres, das quais 95\%, quando comparado com $65 \%$ dos homens, tiveram mais de uma relação sexual por semana. $\left(\chi^{2}=22,97, p=0,0001\right)$.

Tabela 7. Análise univariada comparando soroprevalência por gênero, entre usuários de drogas injetáveis da cidade de Santos, 1991-1993.

\begin{tabular}{lrrrrr}
\hline Gênero & HIV & Sífilis & Hep.B & Hep.C & HTLV(1ou2) \\
\hline masculino & 0,59 & 0,25 & 0,70 & 0,72 & 0,20 \\
feminino & 0,67 & 0,46 & 0,82 & 0,77 & 0,30 \\
$\chi^{2}$ & 1,49 & 8,62 & 3,90 & 0,94 & 2,65 \\
$\mathrm{p}$ & 0,222 & 0,003 & 0,048 & 0,332 & 0,103 \\
\hline
\end{tabular}


$\mathrm{Na}$ tabela 8 são apresentadas as soroprevalências destas infecções avaliando-se a prostituição como fator de risco entre as mulheres. Pode se observar uma maior soroprevalência de sífilis entre as prostitutas, explicado provavelmente pela maior atividade sexual deste grupo.

Tabela 8. Análise univariada comparando soroprevalência entre prostitutas e não prostitutas, entre usuários de drogas injetáveis, na cidade de Santos, 1991-1993.

\begin{tabular}{lrrrrr}
\hline prostitutas & HIV & Sífilis & Hep.B & Hep.C & HTLV(1ou2) \\
\hline Sim & 0,64 & 0,57 & 0,78 & 0,73 & 0,31 \\
Não & 0,69 & 0,31 & 0,86 & 0,84 & 0,31 \\
$\chi^{2}$ & 0,23 & 5,54 & 0,94 & 1,29 & 0,00 \\
$\mathrm{p}$ & 0,63 & 0,0186 & 0,33 & 0,257 & 0,97 \\
\hline
\end{tabular}

Outro aspecto interessante é que entre dos 147 indivíduos com sorologia positiva para hepatite $\mathrm{B}$, a prevalência do AgHBs positivo foi de $15 \%$ comparado com $2 \%$ entre os 45 doadores de sangue (teste de Fisher bicaudal, $\boldsymbol{p}=\mathbf{0 , 0 2 5 6}$ ). No entanto, a alta prevalência de AgHBs encontrada entre os UDIs está fortemente correlacionada com a prevalência do HIV que foi de $15 \%$ entre os HIV positivos comparado com 5\% entre os HIV negativos (teste de Fisher monocaudal $p=0,03166$ ). 


\section{Análise de fatores de risco}

\section{Análise univariada}

Os resultados da análise univariada dos fatores de risco, relacionados com a soroprevalência do HIV, é mostrada nas tabelas 9 e 9 a.

Na tabela 9 são apresentados os fatores de risco que mostraram associação significativa com a infecção pelo HIV, em ordem decrescente de valores de $\boldsymbol{p}$, onde a mudança de comportamento apresenta-se como o mais significativo entre eles. Na tabela 9a, também apresentados em ordem decrescente de valores de $\boldsymbol{p}$, são apresentadas as variáveis que apesar de não apresentarem associação, em nível de 5\%, com a infecção pelo HIV, são consideradas de importancia nesta análise. No entanto quando considera-se um nível significancia de $10 \%$, todas essas variáveis apresentam-se associadas com a infecção pelo HIV. 
Tabela 9. Análise univariada relacionando soroprevalência de infecção pelo HIV e algumas variáveis independentes de comportamento, entre usuários de drogas injetáveis na cidade de Santos, 1991-1993.

\begin{tabular}{|c|c|c|c|c|}
\hline variáveis & $\mathrm{n}$ & $(\%) \mathrm{HIV}+$ & $\chi^{2}$ & $p$ \\
\hline - mudança de comportamento & * & & & \\
\hline $\operatorname{sim}$ & 92 & 46 & 19,0 & 0,000013 \\
\hline não & 104 & 77 & & \\
\hline \multicolumn{5}{|l|}{ - taxa diária de injeção de drogas } \\
\hline$<1 \mathrm{vez} / \mathrm{dia}$ & 88 & 27 & 21,68 & 0,000019 \\
\hline entre 1 e 5 & 87 & 55 & & \\
\hline$\geq 5$ & 22 & 77 & & \\
\hline \multicolumn{5}{|l|}{ - freqüência de injeção de drogas } \\
\hline$£ 4$ dias/mês & 50 & 52 & 12,08 & 0,002377 \\
\hline entre 4 e 15 dias/mês & 53 & 49 & & \\
\hline$>15$ dias/mês & 94 & 75 & & \\
\hline \multicolumn{5}{|c|}{$\begin{array}{l}\text { - uso de droga injetável nos últimos } \\
2 \text { meses }\end{array}$} \\
\hline $\operatorname{sim}$ & 95 & 73 & 8,91 & 0,0028 \\
\hline não & 102 & 52 & & \\
\hline \multicolumn{5}{|c|}{$\begin{array}{l}\text { - uso de drogas injetáveis com agulha } \\
\text { e seringas usadas }\end{array}$} \\
\hline nunca & 90 & 50 & 15,64 & 0,003543 \\
\hline $1 \mathrm{vez} / \mathrm{mes}$ & 42 & 69 & & \\
\hline $1 \mathrm{vez} /$ semana & 23 & 61 & & \\
\hline todo dia & 41 & 83 & & \\
\hline \multicolumn{4}{|c|}{ - uso de droga injetável fora de Santos } & pelo menos $1 \mathrm{vez}$ \\
\hline \multirow[t]{2}{*}{ nunca } & 95 & 72 & 7,25 & 0,007102 \\
\hline & 102 & 53 & & \\
\hline
\end{tabular}


Tabela 9a. Análise univariada relacionando soroprevalência de infecção pelo HIV e algumas variáveis, independentes de comportamento, entre usuários de drogas injetáveis na cidade de Santos, 1991-1993.

\begin{tabular}{|c|c|c|c|c|}
\hline variáveis & $\mathrm{n}$ & $(\%) \mathrm{HIV}+$ & $\chi^{2}$ & $p$ \\
\hline \multicolumn{5}{|l|}{ - limpeza de agulhas e seringas } \\
\hline sempre & 43 & 74 & 3,64 & 0,056428 \\
\hline não sempre & 154 & 58 & & \\
\hline \multicolumn{5}{|l|}{$\begin{array}{l}\text { - compartilhamento de agulhas e } \\
\text { seringas }\end{array}$} \\
\hline pelo menos uma vez & 157 & 65 & 3,03 & 0,08177 \\
\hline nunca & 40 & 50 & & \\
\hline \multicolumn{5}{|l|}{ • Gênero } \\
\hline masculino & 118 & 58 & 1,49 & 0,222 \\
\hline feminino & 79 & 67 & & \\
\hline \multicolumn{5}{|l|}{ - adequação da desinfecção } \\
\hline adequada & 8 & 75 & $* *$ & 0,354137 \\
\hline não & 184 & 61 & & \\
\hline \multicolumn{5}{|l|}{ - Prostituição } \\
\hline $\operatorname{sim}$ & 50 & 64 & 0,12 & 0,7290 \\
\hline não & 147 & 61 & & \\
\hline \multicolumn{5}{|l|}{ - idade em que injetou pela primeira vez } \\
\hline \multicolumn{5}{|l|}{$<18$ anos } \\
\hline \multirow[t]{2}{*}{$\geq 18$ anos } & 84 & 61 & 0,09 & 0,7621 \\
\hline & 113 & 63 & & \\
\hline \multicolumn{5}{|l|}{ - Tempo de uso } \\
\hline$<5$ anos & 58 & 64 & 0,004 & 0,8516 \\
\hline$\geq 5$ anos & 139 & 61 & & \\
\hline \multicolumn{5}{|l|}{$\begin{array}{l}\text { - sexo homem/homem nos últimos } \\
5 \text { anos }\end{array}$} \\
\hline \multirow{2}{*}{$\begin{array}{l}\text { sim } \\
\text { não }\end{array}$} & 57 & 53 & 0,000 & 0,9772 \\
\hline & 34 & 53 & & \\
\hline
\end{tabular}

*informação ausente

**teste de Fisher 
Na tabela 10 foi comparada variáveis de comportamento, com relação ao uso de drogas injetáveis, segundo gênero e, observou-se que o uso todo o dia foi a variável que apresentou maior diferença significativa.

Tabela 10. Análise univariada comparando variáveis de comportamento segundo gênero, num grupo de usuários de drogas injetáveis na cidade de Santos, 1991-1993.

\begin{tabular}{lrrrr}
\hline Gênero & $\begin{array}{r}\text { uso de droga } \\
\text { injetável todo dia }\end{array}$ & $\begin{array}{r}\text { mais de 5 injeções } \\
\text { de drogas no dia }\end{array}$ & $\begin{array}{r}\text { uso de droga injetável } \\
\text { nos últimos 2 meses }\end{array}$ & $\begin{array}{r}\text { Primeiro uso com } \\
\text { menos de 18 anos de } \\
\text { idade }\end{array}$ \\
\hline $\begin{array}{c}\text { masculin } \\
\text { o }\end{array}$ & 0,246 & 0,398 & 0,5 & 0,407 \\
feminino & 0,418 & 0,519 & 0,456 & 0,456 \\
$\chi^{2}$ & 6,49 & 2,79 & 0,370 & 0,46 \\
$\mathrm{p}$ & 0,011 & 0,095 & 0,542 & 0,496 \\
\hline
\end{tabular}

\section{Análise multivariada}

$\mathrm{Na}$ análise multivariada foi utilizada a regressão logística onde considerouse o HIV como variável dependente e, como independentes, aquelas que apresentaram valores significativos na análise univariada. Outras, pelo grande potencial de serem variáveis de confusão,, apesar de não terem apresentado valores significativos, participaram da análise (fatores de risco analisados nas tabelas 9 e 9a, com nível de significância de 10\%). Os resultados desta análise estão apresentados na tabela 11. 
Tabela 11. Regressão logística para risco de infecção pelo HIV, avaliando as variáveis independentes de comportamento, entre usuários de drogas injetáveis na cidade de Santos, 1991-1993, com valores significativos de Odds Ratio (OR).

\begin{tabular}{lccc}
\hline variáveis & OR & limite inferior & limite superior \\
\hline $\begin{array}{l}\text { uso de droga injetável } \\
\text { maior que 5 vezes ao dia }\end{array}$ & 6,73 & 1,76 & \\
$\begin{array}{l}\text { mudança } \\
\text { comportamento para } \\
\text { evitar AIDS }\end{array}$ & 3,28 & 1,67 & 6,43 \\
$\begin{array}{l}\text { uso de droga injetável } \\
\text { maior que15 dias por } \\
\text { mês }\end{array}$ & 2,72 & & \\
uso de droga injetável nos & & 1,02 & 7,35 \\
últimos 2 meses & 2,23 & & \\
\hline
\end{tabular}

nível de significância de $5 \%$

Ao nível de 5\% de significância, o risco para infecção pelo HIV, foi associado positivamente com a taxa diária de injeções maior que 5 vezes, mudança de comportamento no sentido de evitar a AIDS após conhecimento acerca da infecção, uso de droga injetável numa freqüência maior que 15 dias por mês e, finalmente, o uso de droga injetável nos últimos 2 meses.

\section{Análise matemática}

\section{Estimando Ro para uma comunidade de UDIs em Santos}

Com a aplicação dos conceitos descritos de $\boldsymbol{R}_{\boldsymbol{O}}$ para "agulhas", utilizamos os parâmetros necessários para calcular os valores de $\boldsymbol{R}_{\boldsymbol{0}}, \boldsymbol{y}$ e $\boldsymbol{p}$ para esta comunidade de UDIs. Além da obtenção de alguns parâmetros pelos questionários, outros foram determinados por dados de literatura. Os resultados aqui apresentados têm a intenção de exemplificar a teoria proposta. Esta amostra representa uma comunidade isolada, onde todos se relacionam entre si, conforme foi considerado pelo modelo. 
A freqüência no uso de drogas injetáveis, nesta população, mostrou-se bastante diversificada ( 1 a 31 dias por mes), com um número de injeções, em cada dia, variando de 1 a 50 .

O número de "agulhas" por indivíduo, $\boldsymbol{m}$, foi considerado como sendo dependente somente da viabilidade das "agulhas", e não dos hábitos dos UDIs. No entanto, calculamos este valor pela mediana dos valores de $\boldsymbol{a}$ (número de "picadas" por "agulha" por indivíduo) e ma (número diário de "picadas" por UDI) encontrados na população, resultando em 0,7 "agulhas" por indivíduo.

A taxa de "sobrevivência" diária da população de "agulhas", isto é, o período médio de tempo que as "agulhas" são mantidas pelos UDIs foi de $1 / \alpha=2,1$ dias.

A proporção de "agulhas" que se contaminam, depois de picar um indivíduo infectado, $\delta$, foi estimada através dos dados obtidos por 1989[68]. A partir destes dados obteve-se a média de concentração do inóculo efetivo por unidade de sangue, $\varphi$, igual a $30 \mathrm{UITC} / \mathrm{ml}$ e sua respectiva variância $\sigma^{2}=1,0 \times 10^{3}$. Por esta razão, tomando o volume residual encontrado no lumem da agulha como igual a $1,67 \mu$ l (agulha ' $21 \times 4,5^{\prime}$ ) obtemos o valor de $\delta=0,05$ considerando a distribuição de inóculos efetivos como homogênea e $\delta=0,17$ como heterogênea, respectivamente.

Nesta seção, o parâmetro $\boldsymbol{r}$ foi definido como o inverso do período em que um indivíduo permanece na comunidade. Para essa específica comunidade, o valor foi considerado de um ano.

O parâmetro $\mu$, definido como o inverso do período médio em que as "agulhas" perderam a infectividade, foi determinado admitindo-se que este período depende, principalmente, do tempo de coagulação do sangue residual do interior da agulha. Este valor foi estimado em 1,5 minutos ou $965^{-1}$ dias.

A tabela 12 apresenta os valores e a maneira de obtenção dos parâmetros aplicados para estimar-se $\boldsymbol{R}_{\boldsymbol{0}}$. 
Tabela 12. Valores dos parâmetros para a estimação de $R_{0}$, obtidos na comunidade de UDIs da cidade de Santos, 1991-1992.

\begin{tabular}{|c|c|c|c|}
\hline & variável & valor & obtenção da estimativa \\
\hline$\bullet \delta$ & $\begin{array}{l}\text { proporção de "agulhas" que se } \\
\text { infectaram após picar um } \\
\text { indivíduo infectado }\end{array}$ & $0,05 / 0,17$ & $\begin{array}{r}\text { estimado em } \\
(\text { Massad, } 1994 \text { [94]) }\end{array}$ \\
\hline$\bullet a$ & $\begin{array}{l}\text { mediana do número dias por } \\
\text { mês de injeção de drogas }\end{array}$ & $11,55 \operatorname{dias}^{-1}$ & questionário \\
\hline$\bullet \mathrm{m}$ & $\begin{array}{l}\text { mediana do número de injeção } \\
\text { de drogas no dia }\end{array}$ & 0,7 vezes & questionário \\
\hline$\bullet$ ma & $\begin{array}{l}\text { mediana do número de } \\
\text { injeções de drogas por } \\
\text { indivíduo por dia }\end{array}$ & 8,085 vezes/dia & questionário \\
\hline$\bullet r$ & $\begin{array}{l}\text { período médio de permanência } \\
\text { do usuário na comunidade }\end{array}$ & $365 \operatorname{dias}^{-1}$ & assumido pelo modelo \\
\hline$\bullet \alpha$ & $\begin{array}{l}\text { número de } \\
\text { "agulha" é guardada } \\
\text { reutilização }\end{array}$ & $2,1 \operatorname{dias}^{-1}$ & questionário \\
\hline$\bullet \mu$ & $\begin{array}{l}\text { período médio de tempo que } \\
\text { uma "agulha" permanece } \\
\text { infectante }\end{array}$ & $960 \operatorname{dias}^{-1}$ & $\begin{array}{l}\text { assumido como o tempo de } \\
\text { coagulação do sangue }\end{array}$ \\
\hline
\end{tabular}

Os valores encontrados para $\boldsymbol{R}_{\boldsymbol{0}}$ foram de 28 e 98 , considerando a distribuição homogênea e heterogênea para o inóculo infectante $(\delta)$, isto é, 0,05 e 0,17 respectivamente. Estes valores podem ser comparados aos encontrados para transmissão sexual pelo HIV, estimados entre 10 e 12 (1982[3]). Para esta comunidade, em particular, a prevalência da infecção pelo HIV em equilíbrio, $\mathbf{y}^{*}$, foi de $67 \%$, que poderia ser comparada com o valor atual encontrado (62\%).

Nossos resultados apontam não somente para uma boa concordância entre a teoria e a prática, mas, também, o fato desta específica comunidade apresentar um valor de prevalência bem próximo de seu nível teórico de equilíbrio endêmico. 


\section{Discussão}

A s mudanças observadas no papel do Brasil no tráfico internacional de drogas, somadas às alterações no padrão do uso local de drogas, são causas importantes da maneira como a epidemia de AIDS está se comportando no país, e que devem ser consideradas. No passado, o Brasil servia somente como rota para o tráfico da cocaína, proveniente dos países produtores (Colômbia e Bolívia principalmente), para os países consumidores da Europa e América do Norte. No entanto, o aumento local no consumo destas drogas observado no anos 80 e, mais recentemente, demonstra que há indícios do estabelecimento de organizações ligadas ao narcotráfico internacional (1992[99]). Isto faz com que estudos no sentido de melhor compreender os padrões do uso de drogas e seu impacto na transmissão do HIV/AIDS e infecções correlatas sejam altamente desejáveis.

Este trabalho compreende um estudo da soroprevalência para HIV e infecções de padrão de transmissão semelhante (HBV, HCV, Sifilis e HTLV), com detalhado estudo comportamental entre os UDIs, na cidade de Santos.

É estimado que a comunidade de UDIs, em Santos, represente $2 \%$ de sua população (1993[113]). A mediana da intensidade do uso de drogas injetáveis na amostra estudada foi de 16,5 dias por mês, e a mediana da taxa diária de injeções de droga foi de 7,4 injeções por dia. Como foi mencionado acima, acreditamos que isto ocorra pelo fato de a droga mais utilizada nesta comunidade ter sido a cocaína, apesar deste hábito também poder ser observado em alguns indivíduos que se utilizam de outras drogas injetáveis como, por exemplo, a heroína. Esta alta taxa de injeções de drogas associada à falta de programas de controle, especificamente dirigidos aos UDIs, vai se refletir em dramáticas conseqüências na sociedade como um todo. Além do impacto econômico e social, o uso de drogas injetáveis, traz graves conseqüências do ponto de vista da saúde pública, particularmente na 
disseminação do HIV, hepatites, HTLV e sífilis entre os UDIs e seus parceiros sexuais como também às crianças através, principalmente, da transmissão vertical.

Observou-se que a amostra estudada tinha um grau razoável de educação, com um número médio de anos de educação formal acima da média nacional (1993[113]). Apesar disto, somente 18\% estavam empregados na época da coleta de dados. Constatou-se, também, que a grande maioria da amostra (77\%) esteve presa pelo menos uma vez na vida.

Considerando a virtual ausência de programas de prevenção da infecção, é de se esperar uma alta prevalência de infecção pelo HIV nesta comunidade. Esta projeção foi confirmada, mostrando que a comunidade de UDIs de Santos apresenta uma das maiores prevalências de HIV dentre as cidades estudadas, envolvidas no WHO Multicity Study of HIV among IDUs (1994[114]).

De particular interesse são os resultados apresentados na tabela 6 e figura 5, que comparam a soroprevalência do HIV, hepatites B e C, sífilis e HTLV (1 ou 2), entre UDIs e doadores de sangue pareados por idade e sexo. Deve-se notar que o $\boldsymbol{O} \boldsymbol{R}$ para sífilis em UDIs é 3,57 (2,08-6,25), quando comparado com doadores de sangue, o que aponta para uma alta exposição desta comunidade às doenças sexualmente transmissíveis (STD). Em contraste, o $\boldsymbol{O R}$ para hepatite $\mathrm{C}$ foi 100 (50-200) comparando os mesmos grupos, o que mostra o alto risco deste grupo para doenças de transmissão parenteral, embora a transmissão de STD seja também significativamente maior que a população geral $\left(1989^{[8]}, 1990^{[138]}, 1966^{[140]}\right)$. Em vista dos resultados apresentados, a saúde pública deveria se apoiar no fato, geralmente negligenciado, de que os UDIs podem desempenhar importante papel na disseminação do HIV, via transmissão sexual, para outras comunidades como um todo. Isto está de acordo com os dados de literatura, que demonstram os UDIs como importante fonte de infecção de STDs e HIV (1990[134]).

Um aspecto interessante desta amostra é o número relativamente alto de mulheres recrutadas - $40 \%$ da amostra-, quando comparado com outros locais, onde o estudo multicêntrico ocorreu (1993[113]). Isto nos permite comparar homens e mulheres com relação a fatores de risco, como também para soroprevalência, o que não foi possível ser avaliado em outros locais. Encontramos uma diferença marginal $(\mathrm{p}=0,095)$ de hábito no uso de drogas injetáveis, com um elevado número de mulheres fazendo uso de drogas injetáveis mais de 5 vezes ao dia. As mulheres também mostraram uma grande porcentagem de alta intensidade 
de contatos sexuais e uma maior prevalência de prostituição. Por outro lado, elas relatam um maior uso de condons, tanto com parceiros regulares quanto com parceiros ocasionais.. Em concordância com os fatores de risco analisados, existe uma correspondente diferença na prevalência de sífilis (duas vezes maior que nos homens). Também a soroprevalência de hepatite B foi significativamente maior nas mulheres, embora esta diferença não seja tão pronunciada como na sífilis. Estes achados refletem a alta atividade sexual das mulheres, sendo menor a importância, para a hepatite $\mathrm{B}$, porque esta pode ser atribuída ao componente parenteral de sua transmissão.

A análise univariada comparando a soroprevalência entre UDIs e doadores de sangue tem mostrado um importante aspecto, relacionado com a possibilidade da hepatite C ser um bom indicador de transmissão parenteral do HIV (1994[83]). Como pode-se notar na tabela 6 , ambos os grupos, UDIs e doadores de sangue, apresentam um razoável nível de maior exposição às DSTs, observado na soroprevalência para sífilis.

Apesar deste fato, observa-se que a prevalência de hepatite $\mathrm{C}$ para os doadores é a mesma esperada para as comunidades em geral (1989[34], 1989[79], $\left.1989^{[121]}, 1991^{[69]}, 1991^{[37]}, 1991^{[53]}, 1992^{[52]}, 1992^{[81]}, 1993^{137]}\right) . \quad$ Em contraste, a Hepatite $\mathrm{C}$ foi 100 vezes mais prevalente na amostra de UDIs, o que deve ser comparado com o risco para sífilis $(3,57)$ e para hepatite $\mathrm{B}(10,0)$.

A análise multivariada demonstrou como fatores de risco para infecção pelo HIV, somente aqueles relacionados à transmissão parenteral, sendo que o uso de drogas repetidas vezes no mesmo dia, foi o mais significante. Deve ser mencionado que, embora a freqüência de injeções de drogas (expressa em dias por mês) não tenha sido significativamente associada à infecção pelo HIV, o uso de droga, mais de 5 vezes ao dia, demonstrou um risco 6,7 vezes maior do que aqueles que faziam uso da droga menos de 5 vezes ao dia.

A associação encontrada para doses repetidas no mesmo dia com a infecção pelo HIV reforça a hipótese usada para a estimação de $\boldsymbol{R}_{\boldsymbol{0}}$. Isto pode ser compreendido supondo que doses repetidas estão associadas com infecção pelo HIV somente quando não existir coágulo dentro do lúmen da "agulha".

A análise univariada comparando a soroprevalência para HIV em relação ao comportamento é resumido nas tabelas 9 e 9a, que registram os resultados que se mostraram significantes. 
Um dos mais importantes resultados deste trabalho, no que compete às medidas de controle, é o fato da mudança de hábitos de risco, após conhecimento das medidas de prevenção da AIDS, estar significativamente associada, à proteção contra infecção pelo HIV. Este dado, ao contrário do que possa parecer, aponta para o fato de que o UDI preocupa-se com a própria saúde e com a dos outros, apesar de ser contraditória sua atitude diante das drogas.

Como este grupo de UDIs não sofreu nenhuma ação sistemática de intervenção até o momento deste trabalho, sob a luz destes resultados, torna-se clara a urgência da implantação de programas de controle, para que se possa amenizar o avanço da epidemia, (1992[73], 1993[39], 1993[142] $\left.1993^{[98]}\right)$, como aqueles de San Francisco, Glasgow, Mersey, Sidney e outros, com o objetivo de reduzir a infecção pelo HIV.

Finalmente, uma substancial parcela de nossa amostra mencionou, como uma importante razão para compartilhamento de "agulhas", o medo dos efeitos da droga, incluindo a overdose. Infelizmente, não fez parte do questionário este tipo de avaliação e, portanto, não há como mensurar este fato. É um ponto que deveria ser levantado em futuros estudos.

\section{Comentários finais}

Os parâmetros estimados devem ser de grande valor para o desenvolvimento de ferramentas com capacidade preditiva, como, por exemplo, a estimação de $\boldsymbol{R}_{\boldsymbol{0}}$, para HIV, dando uma melhor idéia da transmissão dentro da comunidade estudada. Os parâmetros derivados, como a taxa de inoculação, $\boldsymbol{h}$, podem ser aplicados para modelos dinâmicos de transmissão do HIV sendo útil na predição futura do comportamento do sistema e do desenho de estatégias de controle. Assim, um programa particular de controle, como o de trocas de agulhas e seringas, pode ter um impacto nos parâmetros específicos relacionados com o cálculo de $\boldsymbol{R}_{\boldsymbol{0}}$. Este programa poderia aumentar a taxa de mortalidade das "agulhas", $\alpha$., e poderia diminuir a média diária de picadas, $\boldsymbol{a}$, das "agulhas". De outro lado, a densidade de "agulhas", relacionadas com a população de homens, $\boldsymbol{m}$, poderia aumentar. No entanto, como o número médio de picadas por agulha, $\boldsymbol{a}$, tem seu valor elevado ao quadrado na equação (67), este efeito pode ser mais determinante na redução do valor de $\boldsymbol{R}_{\boldsymbol{0}}$. Adicionando-se a isto, a limpeza de "agulhas" e seringas, poderia aumentar o valor de $\mu$ significativamente. Além 
disso, a densidade crítica das "agulhas", abaixo da qual a infecção desapareceria da comunidade, poderia, ao menos teóricamente, ser estimada pelo método proposto. Este parâmetro, no entanto, teria pouco significado epidemiológico, no caso dos UDIs.

A analogia com os estudos desenvolvidos por Macdonald, é claramente não realista, porque não considera as heterogeneidades conhecidas que contribuem na transmissão entre os UDIs. Por exemplo, considera que todo UDI tem exatamente o mesmo hábito de uso de droga. Isto implica que toda a agulha tenha a mesma taxa diária de picada. Além disto, a probabilidade de uma agulha infectar-se, $\delta$, é considerada como sendo independente da concentração do HIV no sangue. Estas suposições são boas aproximações para o vetor biológico, mas são inapropriadas para para transmissão relacionada com "agulhas" para o HIV.

$\mathrm{O}$ inóculo infectante foi tratado de maneira homogênea $(\boldsymbol{\delta}=\mathbf{0 , 0 5}) \mathrm{e}$ heterogênea $(\boldsymbol{\delta}=\mathbf{0 , 1 7})$ com estimativas de $\boldsymbol{R}_{\boldsymbol{0}}$ de 28 e 98 respectivamente.

Uma característica importante da transmissão do HIV é a de que distintas comunidades têm diferentes padrões de intensidade de transmissão. Assim, qualquer modelo desenhado para a transmissão do HIV deve considerar a possibilidade de mobilidade individual, e os hábitos de compartilhamento com mais de uma comunidade. Isto implica numa estrutura espacial de transmissão, com distintas comunidades representando seguimentos da população como um todo. Esta situação dá condições para a estimação de distintos $\boldsymbol{R}_{\boldsymbol{O}}$ para cada seguimento, dependendo dos hábitos de compartilhamento dentro e entre as comunidades. Neste caso, devemos determinar a matriz ou um grupo de $\boldsymbol{R}_{\boldsymbol{0}}$ para caracterizar a transmissão da infecção, entre os vários grupos (1992[7]). Deve-se notar que esta aproximação é também apropriada para outras vias de transmissão do HIV, como o comportamento sexual que pode ser facilmente adaptado para infecções transmitidas por vetor, como a malária, quando a distribuição geográfica do mosquito é importante.

O valor de $\boldsymbol{R}_{\boldsymbol{O}}$ encontrado para esta comunidade é compatível com a intensidade de transmissão, resultando num valor de $63 \%$ de soroprevalência para o HIV na comunidade. Além disso, a soroprevalência calculada, em equilíbrio, foi igual a $67 \%$. A proporção de "agulhas" infectadas calculada foi de 33\%, embora somente $0,1 \%$ de todas as "agulhas" circulantes estariam infectantes (o último parâmetro não estava sujeito à verificação experimental). 
O método proposto não é desprovido de limitações. Por isso, a dedução do modelo descrito parte de certas condições que não considerem totalmente a situação real. Por exemplo, a população total de UDIs foi considerada como constante no tempo. Além disso, foi assumida uma transmissão exclusivamente dependente de sangue contaminado, sem levar-se em conta outras formas de transmissão, em particular a sexual.

Finalmente, acreditamos que a maior contribuição deste trabalho é propor um caminho alternativo para estimar-se a transmissão de infecções, quantificando um agente patogênico indiretamente transmitido.

Chama a atenção para certas características comportamentais da comunidade de UDIs, ja conhecidos, mas não quantitativamente relatadas, importantes para o desenvolvimento deste trabalho com a transmissão do HIV. Além do mais, esta transmisssão quantificada pode ser útil, no desenho de estratégias de intervenção.

O refinamento da teoria proposta dependerá, obviamente, de um detalhado trabalho de campo, que poderá tornar possível a estimação de parâmetros para os cálculos descritos acima. Já temos um projeto de campo e esperamos, em futuro próximo, estarmos aptos a apresentar estimativas para a transmissão do HIV entre os UDIs, com maior confiabilidade epidemiológica. 


\section{Conclusões}

1. As soroprevalências observadas para as diferentes infecções estudadas nesta amostra de UDIs foram:

$$
\begin{array}{lll}
\text { HIV }=0,62 & \text { hepatite } \mathrm{B}=0,75 & \text { hepatite } \mathrm{C}=0,75 \\
\operatorname{HTLV}(1 \text { ou } 2)=0,25 & \text { sífilis }=0,34
\end{array}
$$

2. As soroprevalências observadas para as diferentes infecções estudadas na amostra de doadores de sangue da cidade de Santos, pareados por idade e sexo com a amostra de UDIs foram:

$$
\begin{array}{lll}
\text { HIV }=0,00 & \text { hepatite } \mathrm{B}=0,23 & \text { hepatite } \mathrm{C}=0,02 \\
\operatorname{HTLV}(1 \text { ou } 2)=0,01 & \text { sífilis }=0,12
\end{array}
$$

3. Apesar das soroprevalências de algumas das infecções estudadas no grupo do banco de sangue serem um pouco maior que o padrão encontrado na população em geral, observou-se:

para sífilis, marcador sexual da transmissão do $H I V$, o OR igual a 3,57 (2.08-6.25) aponta para uma maior exposição deste grupo para DSTs.

para hepatite $\mathrm{C}$, marcador parenteral da transmissão do $H I V$, o OR igual a $100(50-200)$ aponta para o alto risco da transmissão parenteral entre os UDIs.

Estes dados sugerem que o componente parenteral da transmissão pelo HIV nesta população, é o principal, sendo considerado de menor importância o componente sexual quando comparado ao parenteral.

4. Foi observado neste grupo de UDIs que a variável mais de uma relação sexual por semana foi significativamente maior entre as mulheres $\left(c^{2}=22,97, p=0,001\right)$ o que provavelmente justifique a maior 
prevalência de hepatite B $\quad\left(c^{2}=3,90, \quad p=0,048\right) \quad$ e sífilis $\left(c^{2}=8,62, p=0,003\right)$.

Foi observado que as variáveis que apresentaram diferenças significativas para infecção pelo HIV foram as relacionadas com padrão de uso de drogas injetáveis:

taxa diária de injeção de drogas $\left(\boldsymbol{c}^{2}=\mathbf{2 1 , 6 8 ,}, \boldsymbol{p}=\mathbf{0 , 0 0 0 0 1 9}\right)$; freqüência de injeção de drogas $\left(\boldsymbol{c}^{2}=\mathbf{1 2 , 0 8 ,}, \mathbf{p = 0 , 0 0 2}\right)$; uso de drogas injetaveis nos últimos 2 meses $\left(\boldsymbol{c}^{2}=\mathbf{8 , 9 1}, \boldsymbol{p}=\mathbf{0 , 0 0 2 8}\right)$; uso de drogas injetaveis com agulhas e seringas usadas $\left(c^{2}=15,64, p=0,0035\right)$; uso de drogas injetaveis fora de Santos $\left(\boldsymbol{c}^{2}=7,25, \boldsymbol{p}=\mathbf{0 , 0 0 7 1}\right)$; limpeza de agulhas e seringas $\left(\boldsymbol{c}^{2}=\mathbf{3 , 6 4}, \boldsymbol{p}=\mathbf{0 , 0 5 6 4}\right)$; Compartilhamento de agulhas e seringas $\left(c^{2}=3,03, p=0,0817\right)$.

5. A variável "mudança de comportamento para evitar a infecção pelo $H I V^{\prime \prime}$, apareceu associada como fator de proteção para a infecção pelo HIV, com valores significativos na análise univariada $\left(c^{2}=19,0\right.$, $\boldsymbol{p}=\mathbf{0 , 0 0 0 0 1 3 )}$ e na multivariada, ocupando o segundo lugar, com $\mathrm{OR}=3,28$.

6. Os valores estimados de $\boldsymbol{R}_{\boldsymbol{0}}$ para esta amostra de UDIs, foram de 28 e 98, considerando a distribuição homogênea e heterogênea na população para o inóculo (d), isto é, 0,05 e 0,17, respectivamente.

7. O valor da prevalência da infecção pelo HIV no equilíbrio, $y^{*}$, para esta comunidade em particular, foi de 0,67. 
1. Anderson, R.M. The Population Dynamics and Control of Hookworm and Roundworm Infections. In: Population Dynamics of Infectious Diseases: Theory and Applications. (ed. by R.M.Anderson). Chapman and Hall. London New York. 1982.

2. ANDERSON, R.M.; MAY, R.M. Population biology of infectious diseases: part 1. Nature, v.280, p.361-7, 1979.

3. ANDERSON, R.M.; MAY, R.M. Directly transmitted infectious diseases: control by vaccination. Science, v.215, p.1053-60, 1982.

4. ANDERSON, R.M.; MAY, R.M. Vaccination against rubella and measles: quantitative investigation of different policies. J Hyg Camb, v.90, p.259-325, 1983.

5. ANDERSOn, R.M.; MAY, R.M.; Medley, G.F. A preliminary study of the transmission of Human immunodeficiency virus (HIV), the causative agent of AIDS. IMA J Math Appl Med Biol, v.3, p.22963, 1986.

6. Anderson, R.M.; MAY, R.M. Infectious Disease of Humans. Dynamics and Control. Oxford University Press. Oxford, New York, Tokyo. 1991.

7. ANDERSON, R.M.; MAY, R.M. Understanding the AIDS Pandemic. Sci Am, v.266, n.5, p.20-6. 1992.

8. ANDRADE, A.L.S.S., MARTELli C.M.T. Rastreamento sorológico para doenças infecciosas em banco de sangue como indicador de morbidade populacional. Rev Saude Publica, S.Paulo, v.23, p.20-5, 1989.

9. Andrade, A.G.; NiCastri, S.; Tongue, E. Drogas: Atualização em Prevenção e Tratamento, ed. Loyola, São Paulo, 1993.

10. Azevedo Neto, R.S., Silveira, A.S.B., Nokes, D.J., Yang, H.M., Passos, S.D., CARdoso, M.R.A., Massad, E. Rubella seroepidemiology in a non-immunized population of Sao Paulo State, Brazil. Epidemiol Infect, v.113, p.161-73, 1994.

11. Bailey, N.T.J. The Elements of Stochastic Processes with Aplication to the Natural Sciences. John Wilwy \& Sons. New York, London, Sidney, 1964.

12. Barata, L.C.B., Andriguetti, M.T.M., Matos, M.R. Surto de Malária Induzida em Usuários de Drogas Injetáveis. Rev Saude Publica, v.27, n.1, p.9-14, 1993. 
13. Barré-Sinoussi, F.; Chermann, J.C.; Rey, F, Nugeyre M.T., Chamare, S., Gruest, J, Dauguet, C., Axler-Blin, C., VÈzINET-BRun, F., Rouzioux, C, RozemBAuM, W., MonTAgnier, L. Isolation of a T-linphotropic Retrovirus From a Patient at Risk for Acquired Immunodeficiency Syndrome (AIDS). Science, v.220, p.868-71, 1983.

14. Biancarelli, A. Drogas. A Folha de S.Paulo, S.Paulo, 21 novembro, 1993, Suplemento Especial, C-3.

15. BÖCKH, R. Statistisches Jahrbuch der Stadt Berlin, Zwölfter Jahrgang Statistik des Jahres 1884, Berlin, P.Stankiewicz, p.301, 1886 apud DIETZ K, The estimation of the basic reproduction number for infectious diseases. Stat Meth Med Res, v.2, p.23, 1993.

16. Boletim Epidemiológico, Secretaria de Higiene e Saúde de SANTOS, S.Paulo, n.2, Abril, 1984.

17. Boletim Epidemiológico, Secretaria de Higiene e Saúde de SANTOSS.Paulo, n.2, Março, 1991.

18. Boletim Epidemiológico, Secretaria de Higiene e Saúde de SANTOS, n.14, Julho, 1994.

19. Boletim Epidemiológico DE AIDS , Ministério DA SAÚde DST/AIDS, BRASIL Brasília, ano V, n.1, Março, 1992.

20. Boletim Epidemiológico DE AIDS, Ministério dA SAÚde DST/AIDS, BRASIL Brasília, ano VII, n.9, Set./Out./Nov., 1994.

21. Boletim TÉCNico DA FundaÇÃo Nacional da SAúde, Superintendência de Campanhas da Saúde, Divisão de Malária, 1991.

22. Boletim Epidemiológico de AIDS, Secretaria do Estado de S.PAULO, BRASIL 1993.

23. Boletim Epidemiológico de Aids, Secretaria do Estado de S.PAULO, BRASIL, julho, 1994.

24. BRACHMAN, P.S. Transmission and Principles of Control. In: Principles and Pratices of Infectious Dieseases (ed.by G.L.Mandell, Gordon Douglas and J.E.Bennett), chap.11, p.155-8. Churchill Livingstone. New York, Edinburgh, London, Melbourne, 1990. 
25. Burattini,M.N.; Massad, E.; Coutinho, F.A.B. Dynamics of malária transmission based on serological data. Epidemiol Infect, v.111, n.3, p.503-23, 1993.

26. Burattini,M.N.; Massad, E.; Coutinho, F.A.B. Malaria amongst Brasillian indians assessed by a new mathematical model. Epidemiol Infect, v.111, n.3, p.525-37, 1993.

27. Centers For Disease Control - Pneumocystis carinii pneumoniaLos Angeles. MMWR, v.30, p.250-2, 1981.

28. Centers For Disease Control - Pneumocystis carinii pneumonia among persons with hemophilia A. MMWR, v.31, p.365, 1982.

29. Centers For Disease Control - Classification system for Human T-Lymphotopic virus type III/Lymphadenopathy- associated virus infections. J.A.M.A., v.256, p.20-5, 1986.

30. Centers For Disease Control - 1993 Revised Classification System for HIV Infection and Expanded Surveillance Case Definition for AIDS Among Adolecents and Adults. MMWR, v.41 (rr-17), 1992.

31. Centers For Disease Control - 1994 Revised Classification System for Human Immunodeficiency Virus Infection in Children Less Than 13 Years Age. MMWR, v.43 (rr-12), p.1-7, 1994.

32. Chaisson, R.E.; Moss, A.R.; ONISHI, R. Human Immunodeficiency virus infection in heterosexual intravenous drug users in S.Francisco. Am J Public Health, v.77, p.169-72, 1987.

33. Chaisson, R.E.; Bacchetti, P., Osmond, D., Brodie, B., SANDE, M.A., Moss, A.R. Cocaine use and HIV injection in intravenous drug users in San Francisco. JAMA, v.261, n.4, p.561$5,1989$.

34. Choo Q.L., Kuo G., WeINER A.J. Isolation of a cDNA Clone Derived from Blood-Born non-A, non-B viral hepatitis genome. Science, v.244, p.359-62, 1989.

35. Clavel, F. LAV type II: second rétrovirus associé au SIDA en Afrique de lÓuest. C.R.Acad.Paris, v.302, p.485-8, 1986.

36. Coutinho, F.A.B.; Massad, E.; Burattini, M.N., YAng, H.M., AZEVEDO NETO, R.S. Effects af vacination programmes on transmission rates of infections and related threshold conditions for control. HIMA J Math Appl Med Biol, v.10, p.187-206, 1993. 
37. DAwson G.J., LESNIEWSKI R.R., STEWART J.L. Detection of antibodies to hepatitis $\mathrm{C}$ virus in US blood donors. J Clin Microbiol, v.29, p.551-6, 1991.

38. Dean A.D., Dean J.A., Burton J.H., Dicker R.C. Epiinfo, version $5:$ a word processing, data base, and statistics program for epidemiology on microcomputers. $C D C$, Atlanta, Georgia, USA, 1990.

39. Des Jarlais D.C., Friedman S.R. Critical issues regarding AIDS among injecting drug users. The global diffusion of injecting drug use: implications for human immunodeficiency virus infection. Bull Narc, v.45, n.1, p.61-75, 1993.

40. Des Jarlais D.C., Friedman S.R. AIDS and the use of injected drugs. Sci Am, v.270, n.2, p.56-62, 1994.

41. Diekmann, O, Dietz K., Heesterbeek, J.A.P. The basic reprodutction ratio for sexually transmitted diseases:I. Theorical considerations. Math Biosci, v.107, p.325-39, 1991.

42. DiETZ, K. Transmission and control of arbovírus diseases. In: Epidemiology (ed. D. Ludwig \& K. L. Cooke). roceedings of the Society for Industrial and Applied Mathematics, Philadelphia, p.104-121, 1974.

43. DiETZ, K. Transmission and control of arboviroses. In: Ludwing D, Cooke K.L. eds. Proceedings of the SIMS conference on epidemiology. Philadelphia: Society for Industrial and Applied Mathematics, p.104-21, 1975.

44. DieTZ, K, SCHENZLE D. Proportionate mixing models for agedependent infection transmission. JMath Biol; v.95, p.419-36, 1985.

45. DiETZ., K. The estimation of the basic reproduction number for infectious diseases. Statistical Methods in Medical Research, v.2, p.23-41, 1993.

46. DIXON, W.J. BMDP Statistical Software, Inc.University of California, L.A., U.S.A., 1990.

47. Drobkin, J.F. Infections in Parenteral Drug Abusers. In: Principles and Pratices of Infectious Diseases (ed. by G.L.Mandell, Gordon Douglas and J.E.Bennett), chap.288, p.2276-808. Churchill Livingstone. New York, Edinburgh, London, Melbourne, 1990. 
48. Dye, C. The Analysis of Parasite Transmission by Bloodsucking Insects. Annu Rev Entomol, 37:1-19, 1992.

49. EsseX, M. Horizontally and vertically transmited onconaviruses of cats. Adv Cancer Res, v.21, p.175-248, 1975.

50. Essex, M.; Maclane, M.F.; Lee, T.H.; FalK, L.; Howe, C.W.S.; Mullins, J.I.; CABRAdilla, C.; Francis, D.P. Antibodies to cell membrane antigens associated whit human T-cell leukemia virus in patients with AIDS. Science, v.220, p.8859-62, 1983.

51. Essex, M., Knaki, P.J., The origins of the AIDS virus. Sci Am, v.259, n.4, p.44-51, 1988.

52. Esteban J.I., CAmps J., Genesca J., Alter J.H. Blood Safety Current Challenges. Nance S.J.ed, Bethesda.MD. American Association of Blood banks. USA, Cap. 2, p.45-96: Hepatitis C and B: New Developments, 1992.

53. Follett E.A.C., Dow B.C., McOMish F. HCV confirmatory testing of blood donors. Lancet, v.338, p.1024, 1991.

54. Gallo, R.C.; Salahuddin, S.Z.; Popovic, M. Frequent Detection and Isolation of Citopatic Retroviruses. (HTLV-III) From Patients With AIDS And at Risk For AIDS. Science, v.224, p.500-3, 1984.

55. Gallo, R.C.; Montaingner, L. AIDS in 1988. Sci Am, v.259, n.4, p.25-32, 56, 1988.

57. GARRET-JONES. The human blood index of malaria vectors in relation to epidemiological assessment. Bull World Health Organ, 30:241-61, 1964.

58. GARRET-JONES. Prognosis for interruption of malaria-transmission through assessment of the mosquito's vectorial capacity. Nature, 1964; v.204; p.1173-5, 1964.

59. Granato, C.F.H. Estudo Sequencial da Infecção pelo Virus da Imunodeficiência Humana em Grupos Selecionados da Cidade de Santos, São Paulo, Brasil 1989 a 1990. São Paulo, 1991. 91p. Tese (Doutorado) - Escola Paulista de Medicina, Diciplina de Doenças Infecciosas e Parasitárias, 1991.

60. GreEnBerg, S.S. Immunity and Survival Origin of the AIDS. Human Sciences Press, NY, 1989. 
61. GRENFELl, B.T.; ANDERSON, R.M. The estimation of age related rates of infection from case notifications and serological data. J Hyg, v.95, p.419-36, 1985 apud ANDERSON, R.M.; MAY, R.M.; p. $51,1991$.

62. GRIFFEL, D.H. Applied Functional Analysis. John Wiley \& Sons. New York, Brisbane, Chichester, Toronto, 1981.

63. GRIFFITHS, D.A. A catalitic model of infections for masles Appl.Sta. v.23, p.330-9 1974 apud ANDERSON, R.M.; MAY, R.M.; Eds., Infectious Disease of Humans. Dynamics and Control. Oxford University Press. Oxford, New York, Tokyo, p. 51, 1991.

64. Hall, W.W., Kubo, T, IJichi, S, Takahashi, H, Zhu, S.W. CHuman $\mathrm{T}$ cell leukemia/lynphoma virus, tipe II (HTLV-II): emergence of an important newly recognized pathogen. Virology, v.5, p.165$78,1994$.

65. HAMmeR, W.H. A epidemic desease in England. Lancet, v.i, p.73391906 apud ANDERSON, R.M.; MAY, R.M.; Eds., Infectious Disease of Humans. Dynamics and Control. Oxford University Press. Oxford, New York, Tokyo, p. 7, 1991.

66. Haseltine, W.A., Wong-StaAl, F., The molecular biology of the AIDS virus. Sci Am, v.259, n.4, p.34-42, 1988.

67. Hethcote, H.W., Van A.J.W. Epidemiological models for heterogeneous populations: proportionate mixing, parameter estimation, and immunizations programs. Math. Biosci, v.84, p.85-118, 1987.

68. Ho, D.D., Moudgh, T.; Alan, M. Quantification of Human Immunodeficiency Virus Type I in the blood of Infected Persons. N Engl J Med, v.321, p.1621-5, 1989.

69. Hsu H.H., GonZales M., Foung S.K.H. Antibodies to hepatitis C virus in low-risk blood donors: Implications for counselling positive donors. Gastroenterology, v.101, p1724-7, 1991.

70. InStituto BRASILEIRO DE GEOGRAFIA E EstatístiCA - - (IBGE) Anuários Estatísticos: 1980-90, 1990.

71. JACQUEZ, J.A., SIMON, C.P., The reproduction number in deterministic models of contagious diseases. Comments on Theor Biol, v.2, p.159-209, 1991. 
72. Kalianaramam V.S., Sarngadharan, M.G., Robert-Guroff M. A New subtype of human T-cell leukemia virus (HTLV II) associated with a T-cell variant of hairy cell leukemia. Science, v218, p.571-3, 1982.

73. KAPLAN, E.H., HEIMER, R. HIV prevalence among intravenous drug users: model based estimates from New Haven's legal needle exchange. J Acquir Immune Defic Syndr, 5:163-169, 1992.

74. KARPAS, A. Origin of the virus explained? N Sci, v.115, p.67, 1987.

75. Kashamura, A. Famille, sexualite et culture: Essai sur moeurs sexuelles et les cultures des peuples des Grands Lacs Africains. Paris, Paiot, p.137, 1973 apud GreEnBERG, S.S. Immunity and Survival Origin of the AIDS. Human Sciences Press, NY, 1989.

76. KeINDING, N., Age-specific incidence and prevalence: a estatistical perspective, J R Stat Soc, v.154, p.371-412, 1991 apud DIETZ K, The estimation of the basic reproduction number for infectious diseases. Stat Meth Med Res, v.2, p.23, 1993.

77. Kermack, W.O. AND McKendrick, A.G. A contribution to the mathematical theory of epidemics. Proc R Soc Lond [Biol], v.A115, p.700-21 1927 apud ANDERSON, R.M.; MAY, R.M.; Eds., Infectious Disease of Humans. Dynamics and Control. Oxford University Press. Oxford, New York, Tokyo, p. 7, 1991.

78. Krasnov, M.L.; KieseleV, A.I.; MaKarenKo, G.I. Funciones de variable compleja. Cálculo operacional, Teoria de la estabilidad. MIR, Moskow, 1983.

79. Kuo G., Choo Q.L., Alter H.J. An assay for circulating antibodies to a major etiologic virus of human non-A, non-B hepatitis. Science, v.244, p.362-4, 1989.

80. Lifton, A.R. Transmission of the Human Immunodeficiency Virus. In: AIDS Etiology, Diagnosis, Treatment and Prevention 3rd edition (ed. by V.T.DeVita Jr., S.A. Rosemberg), chap.8, p.111120. J.B.Lippincott Company. Philadelphia, 1992.

81. Lima, V.C.P.; ChiantToni, C.S.; Burattini, M.N. Seroprevalence Study of Hepatites C Virus Antibody and HIV 1 Infection Among Volunteers Blood Donnors S.Paulo - Brazil. [Abstracts C355], VIII INTERNATIONAL CONFERENCE ON AIDS, Amsterdam, July, 1992. 
82. LONG, S. China unprepared for growth in AIDS from drug abuse. The Guardian, 5 March, 1990.

83. Longo, M.A.; Noto P.; Tossini G. First demonstration of the main transmission routes for HCV infection in Italy. [Abstract 1353] In: VI International Congress for Infectious Diseases, Prague, Czech Republic, April 26-30, 1994. v.1, p.414, 1994.

84. LotKA, A.J. Théorie analytique des associations biologiques. Deuxième partie. Analise Demographique avec application particulière à léspecie humaine. Paris, Herman, v.102, 1939 apud DIETZ K, The estimation of the basic reproduction number for infectious diseases. Stat. Meth. Med. Res., v.2, p.23, 1993.

85. Macdonald,G. The analysis of infection rates in disease in which superinfection occurs. Bull Trop Dis, 47:907-15, 1950.

86. MACDONALD,G. The analysis of equilibrium in malária. Bull Trop Dis, v.49, p.813-28, 1952.

87. Macdonald,G. The analysis of malaria epidemics Bull Trop Dis, 50:871-89, 1953.

88. MACDONALD,G. Theory of the erradication of malaria. Bull World Health Organ, v.15, p.369-87, 1956.

89. Mandell, G.L., Bennett J.E., Dolin, R. Principles and Pratice of Infectious Disease, $4 \underline{\text { th}}$.ed., Churchill Livingstone Inc., N.York, 1995.

90. Mann, J.; TARAntola, D.J.M.; NetTer, T.W.- AIDS in The World. Havard University Press. USA, 1992.

91. Marques, C.A.; $\quad$ Forattini, O.P.; Massad, E. The basic reproduction number for dengue fever in Sao Paulo state, Brazil: 1990-1991 epidemic. Trans R Soc Trop Med Hyg, v.88, p.58-9, 1994.

92. MASSAD, E. Sobre a Biomatemática das Moléstias Infecciosas : Um Estudo Teórico Exemplificado Por Dois Modelos Originais. São Paulo, 1987. 248p. Tese (Livre Docência) - Faculdade de Medicina da Universidade de São Paulo, 1987.

93. MASSAD, E. Modelos Matemáticos Aplicados à Epidemiologia. IN: ForAtTinI, O.P. - Ecologia e Sociedade, 1992, S.Paulo, Artes Médicas: Ed.USP. 1992. 
94. Massad, E., $\quad$ Coutinho, F.A.B., $\quad$ Burattini, M.N., Carvalho, H.B., Mesquita, F., Yang, H.M. The Basic Reproduction Ratio of HIV Among Intravenous Drug Users. Math. Biosci, v.123, p.227-47 1994.

95. Mastro, T.D., Satten G.A., Nopkesorn, T., Sangkharomya, S., LONGINI JR, I.M. Probability of female-to-male transmission of HIV-1 in Thailand., Lancet, v.343, p.204-7,1994.

96. Masur, J., CARlini, E.A. Drogas - Subsídios para uma discussão. São Paulo. Ed.Brasiliense, 1989.

97. Mckeganey, N., Barnard, M. AIDS, Drugs and Sexual Risk. Open University Press. Buckingham. Philadelphia, 1992.

98. Mersey Regional Health authority. Drug Use and Drugs/HiV Policy in Mersey. England,1993.

99. Mesquita, F. in Em tempos de AIDS - AIDS e Drogas, 1992, Ed. Summus - S.Paulo, Brazil, 1992.

100. Miettinen, O.S.; CooK, E.F. Confounding: Essence and Detection. Am J Epidemiol, v.114, p.593-603, 1981.

101. Miettinen, O.S. Theoretical Epidemiology. New York. John Wiley \& Sons, Inc., 1985.

102. Miettinen, O.S. Striving to deconfound the fundamentals of epidemiologic study design. J Clin Epidemiol, v.41, n.8, p.79$713,1988$.

103. MietTinen, O.S. "Directionality" in epidemiologic research. J Clin Epidemiol, v.42, n.9, p825-6, 1989.

104. MolineauX, L. The prons and cons of moddelling malaria transmission. Trans R Soc Trop Med Hyg, v.79, p.743-7, 1985.

105. Muench, H. Catalytic models in epidemiology. Cambridge, M.A.: Harvard University press, 1959.

106. MuSEVEnI, Y.K. AIDS and Its Impact on the Health, Social and Economic Infrastrure in Developing Countries [foreword] in Science Challenging AIDS, ed.Karger, Basel,1991.

107. NoIREAU, F. Orstom, Brazzaville, Congo, Letter to Lancet, June 27, p.1499, 1987. 
108. O Estado De S.PAUlo, São Paulo, 21 nov., suplemento especial, p.C3, 1993.

109. OrganizaÇão Mundial da SAÚdE Weekly Epidemiological Record, Year 70, n.2, p.5-12, January, 1995.

110. OrganizaÇão Mundial da SAÚde/GPA Field Guidelines for sentinel serosurveillance. Geneva. August 1989, 1989.

111. OrganizaÇão Mundial da SaÚde/GPA - A Current and future dimensions of the AIDS pandemic. Geneva, April, 1991, 1991.

112. ORGANIZAÇÃO Mundial DA SAÚde/GPA/RES/SFI, April 1991/SS21, 1991.

113. OrganizaÇão Mundial da SAÚdE, Collaborattive study group on drug abuse, An international comparative study of HIV prevalence and risk behaviour among drug injectors in 13 cities, Bul Narc, v.45, n.1, p.19-46, 1993.

114. ORganizaÇão Mundial da SAÚde Collaborattive study group on drug abuse - Programme on substance abuse. Multi-city study of HIV/Injection among IDUs. Final Report of the WHO/PSA, 1994 in press.

115. OrganizaÇão Pan-Americana da SAÚde, Documento Informativo de AIDS no Mundo [documento obtido do Escritório Regional da Repartição Sanitária Pan-Americana - CE113/16 (Esp.)], Brasília, 1994.

116. Perez, J.F., Malta, C.P., Coutinho, F.A.B. Qualitative Analysis of Oscillations in Isolated Populations of Flies. J Theor Biol, v.71, p.505-14, 1978.

117. Poiesz, B.J.; $\quad$ Ruscetti, F.W.; $\quad$ Gazdar, A.F.; $\quad$ Bunn, P.A.; MinNA, J.D.; GALlO, R.C. Detection and isolation of type C retrovirus particles from fresh and cultured lynphocytes of a patient with cutaneous T-cell lynphoma. Proc Natl Acad Sci U S A, v.77, p.7415-19, 1980.

118. Poshyachinda V., Drug injecting and HIV infection among the population of drug users in Asia. Bull Narc, v.45, n.1, p.77 - 90, 1993.

119. Prado, F.C., Ramos, J.A., Valle, J.R. Atualização Terapêutica, 14a. .edição, ed. Artes Médicas, S.Paulo, Brazil, 1988. 
120. RedFIELD, R.R., BuRKe, D., HIV infections: The clinical picture. Sci Am, v.259, n.4, p.70-80, , 1988.

121. Roggendorf M.; Deinhardt F.; RASShofer R. Antibodies to hepatites C virus. Lancet, v.ii, p.324-5, 1989.

122. Ross, R. Report on the prevention of malaria in Mauritious . London, Jonh Murray, 1908.

123. Ross, R. The prevention of malaria (2nd ed.) John Murray, London, 1911.

124. Ross, R. Some a priori pathometric equation. Brit Med J. 1:546-7, 1915.

125. Ross, R. An application of the theory of probabilities to the study of a priori pathometry, I Proc R Soc, 92:204-30, 1916.

126. SARKAR. S.; PANDA S., NAIK T.N. Rapid spread of HIV among injecting drug users in north-eastern states of India. Bull Narc, v.45, n.1, p.91-105, 1993.

127. SEADE. Anuários Estatísticos do Estado de São Paulo: 1980-90. São Paulo, 1990.

128. Seydel, R. From equilibrium to Chaos. Paratical Bifurcation and Stability Analysis. Elsevier. New York, Amsterdam, London, 1988.

129. SHANNON, R.E. System simulation; the art and science. Englewood Cliffs, N.J., Prentice-Hall, 1975.

130. Silva, J.P.; Lombardi, R. Drogas: Avanço das Superpotências Criminosas. O Estado de São Paulo, São Paulo, 24 outubro, 1993. suplemento especial, p.H1-6.

131. SMith, C.E.G. Factors in the transmission of virus infections from animals to man. Annu Rev Scien Bas Med, p.125-50, 1964.

132. SMith, C.E.G., Rodrigues, L.C., Fine, P.E.M. Assessment of the protective efficacy of vaccines against common diseases using case-control and cohort studies. Int J Epidemiol, v.13, p.87-93, 1984. 
133. SOPER, M.A. The interpretation of periodicity in desease prevalence. J.R. Stat. Soc. V.A92, p.34-61, 1929 apud ANDERSON, R.M.; MAY, R.M.; Eds., Infectious Disease of Humans. Dynamics and Control. Oxford University Press. Oxford, New York, Tokyo, p. 7, 1991.

134. Stang, J.; Stimson, G. Aids and drug Misuse, Routledge ed., London, New York, 1990.

135. Stimson G.V. The global diffusion of injecting drug use: implications for human immunodeficiency virus infection. Bull Narc, v.45, n.1, p.3-17, 1993.

136. Towbin, H., Staehelin, T., Bordon, J. Electrophoretic transfer of proteins from polyacrylamide gels to nitrocellulose sheets: Procedure and some applications. Proc Natl Acad SciU S A, v.76, p4350-4., 1979.

137. VANDERBORGHT, B.O.M.; REIS A.M.M.; ROUZERE C.D.; Silva, R.S.; Yoshida, C.F.T.; FranCO, L.G.P.; MAERTENS, G., Heuverswijn, H.V.; Pereira, J.M. Prevalence of Anti-Hepatitis $\mathrm{C}$ Virus in the Blood Donnor Population of Rio de Janeiro. Vox Sang, v.65, p.122-5, 1993.

138. Vaz A.J.; Guerra E.M.; AzeVedo Neto R.S. Sorologia positiva para sífilis, toxoplasmose e doença de Chagas em gestantes de primeira consulta em centros de saúde de área metropolitana, Brasil, São Paulo. Rev Saude Publica, v.24, p.373-9, 1990.

139. WeIss, S.H. The Evolving Epidemiology of Human T Lynphotropic Virus Type II. J Infect Dis, v.169, p.1080-3, 1994.

140. Wilcox R.R.; Guthe T. Treponema pallidum. A bibliographical review of the morphology, culture an survival of Treponema pallidum and associated organisms. Bull World Health Organ, v.35, Supplement 1, 1966.

141. Wilson, E.B.; WorCEster, J. The law of mass action in epidemilogy. Proc Natl Acad SciU S A, v.31, p.24-34, 1945.

142. WodAK A.; Des JARLAIS D.C. Strategies for the prevention of HIV infection among and from injecting drug users. Bull Narc, v.45, n.1, p.47-60, 1993. 